\title{
Role of mast cells and probiotics in the regulation of intestinal barrier function
}

\section{Anders Carlsson}

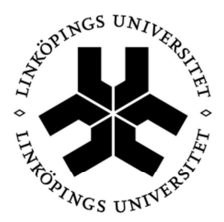

\section{Linköping University \\ FACULTY OF HEALTH SCIENCES}

Division of Clinical Sciences, Surgery

Department of Clinical and Experimental Medicine

Faculty of Health Sciences, Linköping University

SE-581 85 Linköping, SWEDEN 
About the cover

The cover displays immunofluorescence image of intestinal villus epithelium and mast cells. Nuclei are stained blue with DAPI and mast cell tryptase is stained green. The image was acquired on a Zeiss LSM 700.

During the course of the research underlying this thesis, Anders Carlsson was enrolled in Forum GIMIICum, faa national research school in gastrointestinal infection and inflammation funded by the Swedish Research Council and based at Linköping University

The papers included in this thesis have been reprinted with permission of respective copyright holder:

(C) Anders Carlsson, 2013

Paper I: $\quad$ (C) 2013 John Wiley \& Sons Ltd

Paper II: C 2013 Informa Healthcare

The studies in this thesis were supported by The Swedish Research Council

ISBN: 978-91-7519-630-5

ISSN: 0345-0082

Printed by: LiU-Tryck, Linköping 2013 


\section{Papers}

The articles associated with this thesis have been removed for copyright reasons. For more details about these see:

http://urn.kb.se/resolve?urn=urn:nbn:se:liu:diva-100770 
"If you're not part of the solution, you're part of the precipitate." Henry J. Tillman

To my family and friends 
Supervisor:

Professor Johan Dabrosin Söderholm

Linköping University

Co-Supervisor I:

PhD Åsa Keita

Linköping University

Co-Supervisor II:

Professor Karl-Eric Magnusson

Linköping University

Opponent:

Björn Weström

Lund University 


\section{ABSTRACT}

The intestinal mucosa is the largest contact area and one of the most important barriers to the outside environment. It is highly specialized in aiding us digest and absorb nutrients. It is daily exposed to several potentially dangerous substances and microorganisms, which if they were allowed to pass into the body, could give rise to diseases. Throughout the small intestine certain sites specialized in antigen sampling are found. These sites are named Peyer's patches and are lymphoid follicles. The epithelium covering the Peyer's patches is called follicle-associated epithelium and is specialized in antigen sampling and uptake. The special epithelium enables presentation of luminal antigen to immune cells in the underlying follicle.

Persistent life stress and stressful life events affect the course of irritable bowel syndrome (IBS) and inflammatory bowel disease (IBD) through largely unknown mechanisms. Regulation of epithelial permeability to antigens is crucial for the balance between inflammation and immune-surveillance, and increased intestinal permeability has been shown in patients with ulcerative colitis and Crohns disease. Vasoactive intestinal polypeptide (VIP) and corticotropin-releasing factor have been implicated as important mediators of stress-induced abnormalities in intestinal mucosal functions in animal models. Both of these mediators have been reported to regulate bowel ion secretion in humans during stress and uptake of horseradish peroxidase in rodents. Probiotics have been shown to ameliorate the deleterious effects of stress on intestinal function, but mechanisms remain to be elucidated.

The aim of this thesis was to elucidate whether mast cells play an important role in intestinal barrier function during stress and inflammation. Moreover, we wanted to determine whether probiotics can ameliorate the mucosal barrier integrity during stress and inflammation.

To study the function of mast cells we conducted in vitro experiments on cell lines and ex vivo experiments in Ussing chambers on mouse, rat and human intestinal tissue. The Ussing chamber technique measures electrophysiological properties of the tissue and also gives the possibility to study transcellular and paracellular passage of markers and bacteria. Immunohistology and confocal microscopy have been used to identify mast cells and receptors of interest.

Our results show that stress affects the follicle-associated epithelium barrier by mechanisms involving VIP and mast cells. These findings were corroborated by the localization of VIP receptors on mucosal mast cells. Furthermore, pretreatment with probiotics was effective in protecting the gut against stress-induced intestinal barrier dysfunction and mucosal inflammation. This protection appeared to involve a mast cell and peroxisome proliferatoractivated receptor- $\gamma$ dependent mechanism. 


\section{POPULÄRVETENSKAPLIG SAMMANFATTNING}

Tarmslemhinnan fungerar som en barriär som hindrar skadliga bakterier och ämnen från att ta sig in i kroppen samtidigt som den släpper igenom eller aktivt tar upp näringsämnen och vätska. Små områden i tarmen är täckta av det så kallade follikelassocierade epitelet. Detta epitel är specialiserat på att fånga upp och släppa igenom partiklar i tarminnehållet och transportera det till underliggande immunvävnad. Denna funktion är viktig för kroppen då den förbereder immunförsvaret på vad det ska vara berett på att bekämpa.

Inflammatorisk tarmsjukdom är ett samlingsbegrepp som innefattar sjukdomarna Crohns sjukdom och ulcerös kolit. Sjukdomarna karaktäriseras av en kronisk inflammation i tarmens slemhinna med symptom som lös avföring med blod och slem, buksmärtor, samt ibland viktnedgång, feber samt nedsatt allmäntillstånd. I Sverige är förekomsten av inflammatorisk tarmsjukdom relativt hög och uppskattas till $0.5-1.0 \%$ av befolkningen. Orsaken till sjukdomarna är okänd men både arv och miljö är av betydelse. Vid Crohns sjukdom tror man att något går fel vid det follikelassocierade epitelet, vilket leder till ett kraftigt ökat immunsvar som syns på tarmväggen och att det bildas mikroskopiska sår och lätt synliga skador.

Det är sedan tidigare känt att stress påverkar patienter med inflammatorisk tarmsjukdom negativt och att det kan bidra till att patienterna får nya skov. Flera olika signalmolekyler har studerats för att belysa kopplingen mellan stress och immunförsvaret. En sådan signalmolekyl är vasoaktiv intestinal peptid (VIP). Den utsöndras från nerver och skulle kunna spela en nyckelroll i kopplingen mellan nervsystemet och immunförsvaret. Mastcellen är en speciell typ av immuncell i det ospecifika immunförsvararet. Den kan utsöndra inflammatoriska substanser och därmed reglera hur starkt det inflammatoriska svaret blir vid en infektion. Mastceller kan också tänkas reglera tarmslemhinnans svar på stress.

Hos patienter med Crohns sjukdom har analyser utav tarminnehållet visat en minskad mängd av vissa bakterier. Några utav dessa bakterier har visat sig kunna dämpa kroppens inflammatoriska svar på inkräktande bakterier. Då bakterierna har antiinflammatoriska egenskaper är det intressant att studera huruvida behandling med probiotiska "snälla" bakterier har en potential att minska symptomen vid inflammatorisk tarmsjukdom.

Det övergripande syftet med avhandlingen var att studera hur mastcellen reglerar tarmens barriärfunktion vid stress och om regleringen kan påverkas av probiotiska bakterier.

Inledningsvis studerades effekterna av psykologisk stress på råtta. Stressade råttor uppvisade en ökad genomsläpplighet över tarmslemhinna jämfört med kontrolldjur. Den ökade genomsläppligheten kunde minskas genom att blockera effekten av VIP eller genom att hindra mastceller från att utsöndra sina signalmolekyler. Samma resultat kunde ses i operat- 
ionsvävnad från människa och i cellodling där vi tillsatt VIP för att efterlikna utsöndringen som sker i kroppen under stress.

I en musmodell med tjocktarmsinflammation studerades vidare effekten av en specifik probiotisk bakterie, som heter Faecalibacterium prausnitzii (FP). Möss som behandlades med bakterien blev mindre sjuka och återhämtade sig snabbare än de som inte fick bakterien. Fortsättningsvis mättes effekten av en blandning probiotiska bakterier på tarmslemhinnans genomsläpplighet efter stress. Den probiotiska bakterieblandningen minskade genomsläppligheten i normala råttors tarm men hade ingen effekt i tarm från djur som var genetiskt modifierade att sakna mastceller. Den positiva effekten som bakterierna hade på normala råttor kunde dessutom förhindras genom att blockera en specifik signalmolekyl som heter PPAR-p. Resultaten från studien tyder på att effekten från bakterierna förmedlas via denna signalväg och är beroende av mastceller. Vi kunde verifiera effekten från bakterierna i cellodling, där i princip samma resultat kunde påvisas och fler detaljer utrönas. Bakterierna påverkade mastcellerna att förändra sin utsöndringsprofil så att den blev mindre vävnadsskadande och mer inflammationssänkande.

Sammantaget bidrar resultaten från detta avhandlingsarbete med ny kunskap om hur mastcellen deltar i regleringen av tarmens barriärfunktion vid stress och att denna reglering kan påverkas av probiotiska bakterier. Detta ger en möjlig förklaring till varför patienter med inflammatorisk tarmsjukdom ofta upplever förvärrade symptom, när de blir stressade. Vidare tycks probiotiska bakterier ha en positiv effekt på tjocktarmsinflammation och stressreaktioner, effekter som delvis förmedlas via mastcellen. 


\section{LIST OF PAPERS}

\section{Paper I:}

Vasoactive intestinal polypeptide regulates barrier function via mast cells in human intestinal follicle-associated epithelium and during stress in rats

Åsa V Keita, Anders H Carlsson, Maria Cigéhn, Ann-Charlott Ericson AC, Derek M McKay, Johan D Söderholm.

Neurogastroenterol. Motil. 2013 Jun;25(6):e406-17

\section{PAPER II}

Protective Effects of Probiotics on Chronic Stress-Induced Intestinal Permeability in Rats are mediated via Mast Cells and PPARY

Femke Lutgendorff, Anders H Carlsson, Harro M Timmerman, Louis MA Akkermans, Johan D Söderholm.

Manuscript 2013

\section{PAPER III}

Probiotics modulate mast cell degranulation and reduce stress-induced barrier dysfunction in vitro Anders H Carlsson, Femke Lutgendorff, Louis MA Akkermans, Derek M McKay, Johan D Söderholm Manuscript 2013

\section{PAPER IV:}

Faecalibacterium prausnitzii supernatant improves intestinal barrier function in mice DSS colitis Anders H Carlsson, Olena Yakymenko, Fathima Håkansson, Emily Postma, Åsa V Keita, Johan D Söderholm

Scand. J. Gastroenterol. 2013 Oct;48(10):1136-44. 


\section{Publications outside of this thesis}

Yersinia pseudotuberculosis induces transcytosis of nanoparticles across human intestinal villus epithelium via invasin-dependent macropinocytosis.

Ragnarsson EG, Schoultz I, Gullberg E, Carlsson AH, Tafazoli F, Lerm M, Magnusson KE, Söderholm JD, Artursson P. Lab. Invest. 2008 Nov;88(11):1215-26.

Low levels of bile acids increase bacterial uptake in colonic biopsies from patients with collagenous colitis in remission.

Münch A, Söderholm JD, Ost A, Carlsson AH, Magnusson KE, Ström M.

Aliment Pharmacol. Ther. 2011 Apr;33(8):954-60.

The effects of probiotics on barrier function and mucosal pouch microbiota during maintenance treatment for severe pouchitis in patients with ulcerative colitis.

Persborn M, Gerritsen J, Wallon C, Carlsson A, Akkermans LM, Söderholm JD.

Aliment Pharmacol. Ther. 2013 Oct;38(7):772-83. 


\section{ABBREVIATIONS}

$\begin{array}{llll}{ }^{51} \text { Cr-EDTA } & { }^{51} \text { chromium-EDTA } & \text { ISH } & \text { In situ hybridization } \\ \text { ACh } & \text { Acetylcholine } & \text { KETO } & \text { Ketotifen } \\ \text { CD } & \text { Crohn's disease } & \text { M cell } & \text { Membranous cell } \\ \text { CRF } & \text { Corticotropin-releasing } & \text { SED } & \text { Subepithelial dome } \\ & \text { factor } & \text { SP } & \text { Substance P } \\ \text { DOX } & \text { Doxantrazole } & \text { TER } & \text { Transepithelial resistance } \\ \text { E. coli } & \text { Escherichia coli } & \text { TJ } & \text { Tight junction } \\ \text { FAE } & \text { Follicle-associated } & \text { UC } & \text { Ulcerative colitis } \\ & \text { epithelium } & \text { VE } & \text { Villus epithelium } \\ \text { FP } & \text { Faecalibacterium prausnitzii } & \text { VIP } & \text { Vasoactive intestinal } \\ \text { i.p. } & \text { Intraperitoneal } & & \text { polypeptide } \\ \text { IBD } & \text { Intestinal bowel disease } & \text { VPAC } & \text { VIP receptor } \\ \text { IBS } & \text { Irritable bowel syndrome } & \text { WAS } & \text { Water avoidance stress. } \\ \text { IHC } & \text { Immunohistochemistry } & \text { PPAR- }-\gamma & \text { Peroxisome proliferation } \\ \text { IsC } & \text { Short-circuit current } & & \text { activating receptor gamma } \\ \end{array}$




\section{TABLE OF CONTENTS}

\section{Table of Contents}

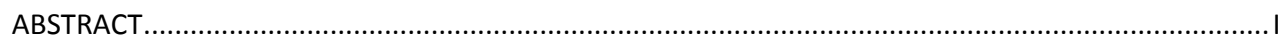

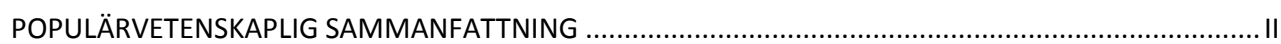

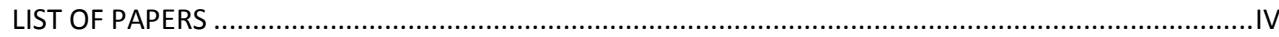

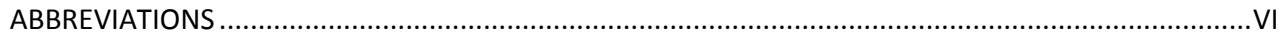

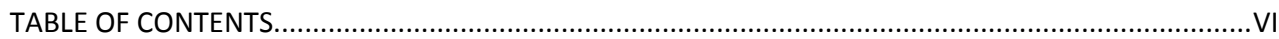

INTRODUCTION

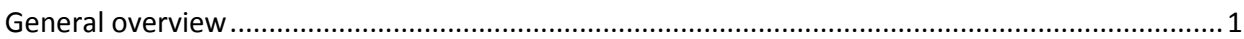

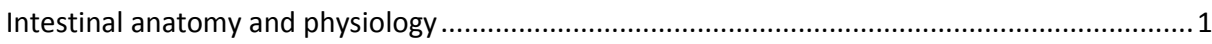

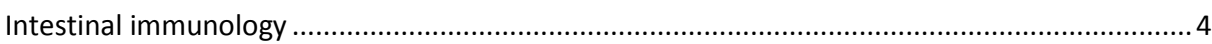

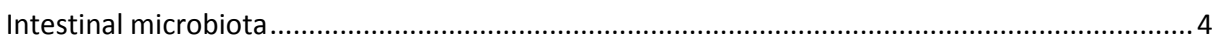

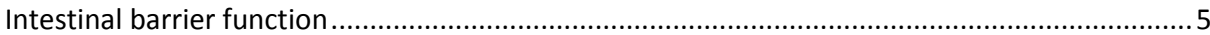

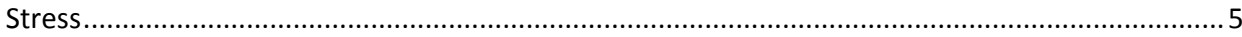

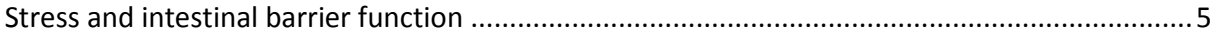

Vasoactive Intestinal Peptide (VIP) and intestinal barrier function........................................... 6

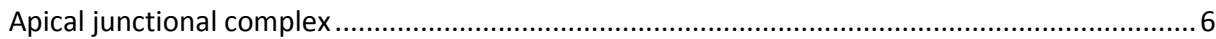

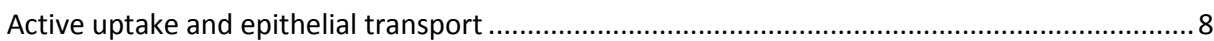

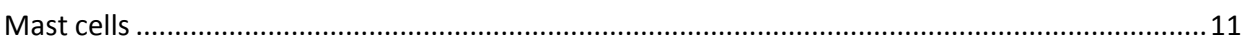

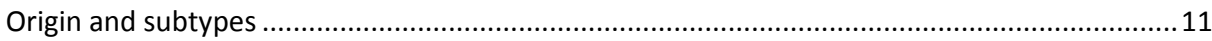

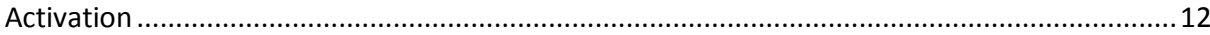

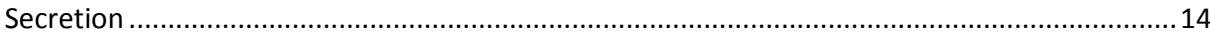

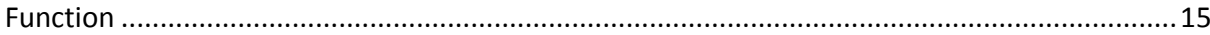

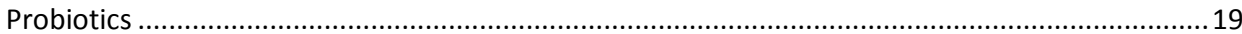

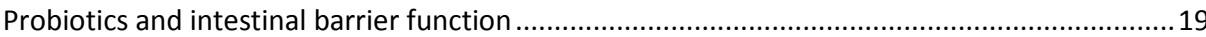

Peroxisome Proliferator-Activated Receptors and intestinal barrier function............................19

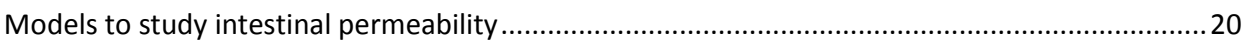

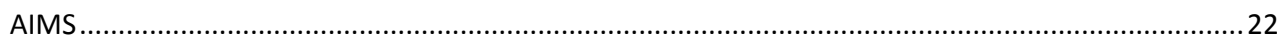

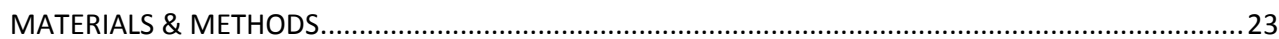

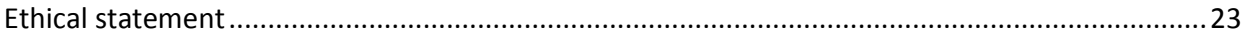

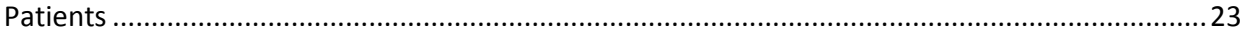

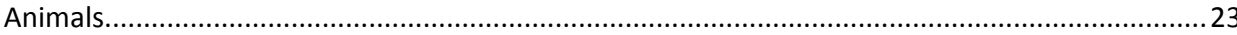




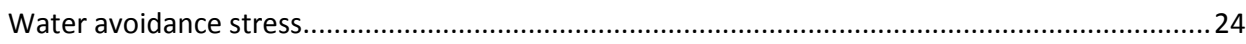

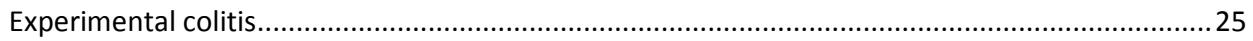

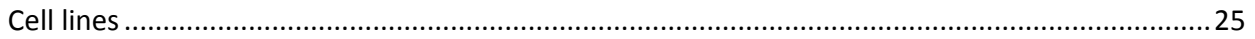

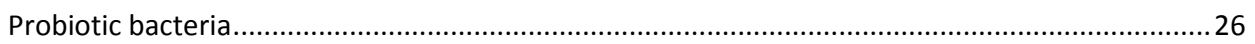

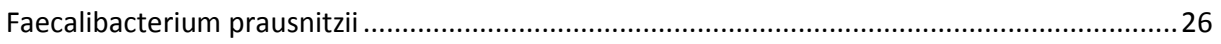

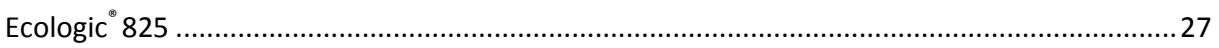

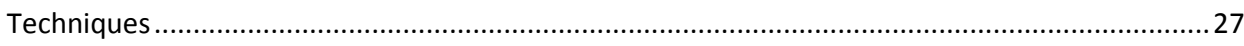

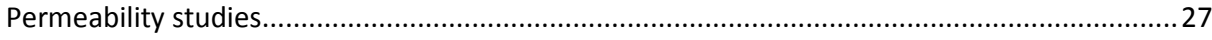

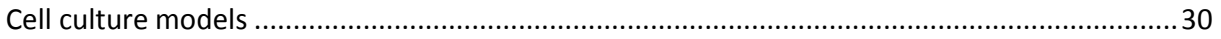

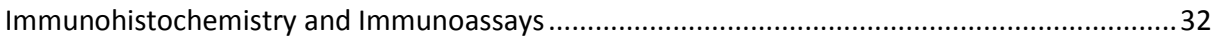

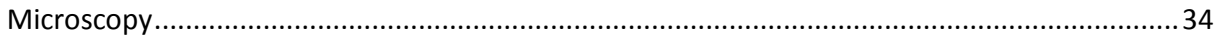

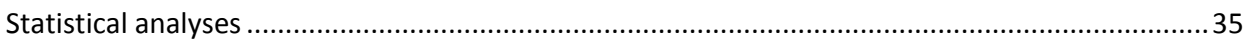

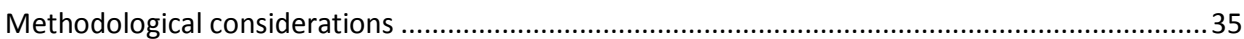

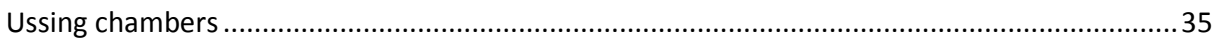

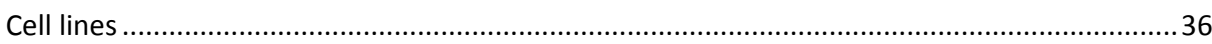

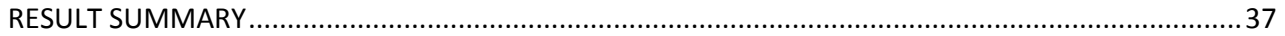

Paper I: Vasoactive intestinal polypeptide regulates barrier function via mast cells in human intestinal follicle-associated epithelium and during stress in rats................................................... 37

Paper II: Role of mast cells and PPARy: Effects of probiotics on chronic stress-induced intestinal

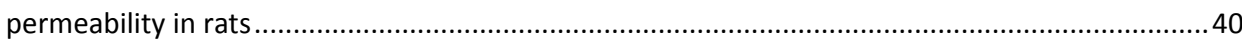

Paper III: Probiotics modulate mast cell degranulation and reduce stress-induced barrier

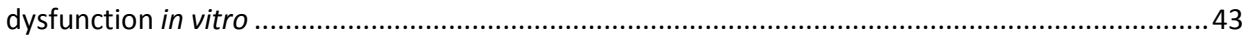

Paper IV: Faecalibacterium prausnitzii supernatant improves intestinal barrier function in mice

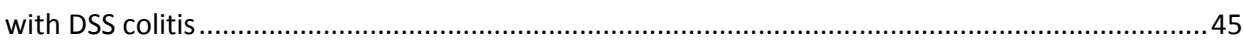

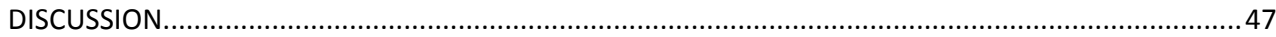

CONCLUSIONS

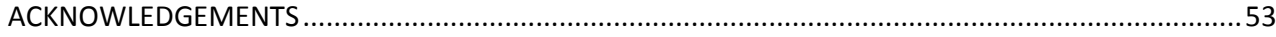

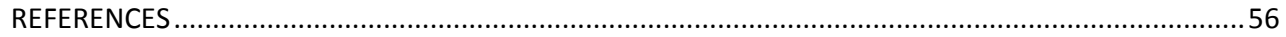




\section{INTRODUCTION}

\section{General overview}

We are constantly threatened by a variety of microbes ranging from viruses and bacteria to parasites. The first line of defense is the barrier function of our intestine, skin, and lungs, which protects us from potentially dangerous organisms. If a microbe succeeds in entering the body, an immune response is necessary. The innate immune response is a non-specific way of eliminating pathogens. If the innate immune system fails to eliminate the pathogen, adaptive immunity takes over with a response that is highly specific towards one particular pathogen.

The intestine is superficially a muscular tube that extends from the lower end of the stomach to the anus. It is divided into two major sections; the small intestine and the large intestine. The intestinal mucosa constitutes one of the largest surface areas that is exposed to and interacts with the external environment. The area of the small intestine itself is about $250 \mathrm{~m}^{2}{ }^{1,2}$, and the gastrointestinal tract plays an important role because it absorbs digested dietary antigens and also serves as sites of innate and adaptive immune regulation. The ability to maintain the delicate balance between absorbing essential nutrients, while preventing entry and responding to potentially harmful contents, forms the foundation of the intestinal mucosal barrier ${ }^{3}$.

\section{Intestinal anatomy and physiology}

The small intestine consists of duodenum, jejunum and ileum. The large intestine is subdivided into the cecum, colon, rectum and anal canal. The total length of the intestine depends on a person's size and age but is usually around 7.5 meters $(6 \mathrm{~m}$ small intestine and $1.5 \mathrm{~m}$ large intestine). A typical cross section of the intestinal wall is shown in figure 1 . The layers from the outer surface and inward are: the serosa, a longitudinal muscle layer, a circular muscle layer, the lamina propria and the epithelium.

The intestinal mucosa is the largest contact area and one of the most important barriers to the outside environment. It is highly specialized in aiding us digest and absorb nutrients.

It is daily exposed to several potentially dangerous substances and microorganisms, which if they were allowed to pass into the body, could give rise to diseases. The ability to hinder these dangerous substances and organisms to enter our body is referred to as barrier function ${ }^{4}$. The intestinal mucosa is continuously exposed to a high content of bacteria and therefore needs to be specialized in controlling the invasion of foreign and dangerous agents. The first step in preventing invasion is a high content of gastric acids and biliary juices in the stomach and duodenum. Adhesion of microbes that survive this environment is further prevented by the mucus layer covering the intestinal epithelium ${ }^{5}$ that constitutes a physical barrier between the intestinal mucosa and the luminal content. The barrier integrity is primarily maintained by enterocytes connected to each other via junctional complexes. 

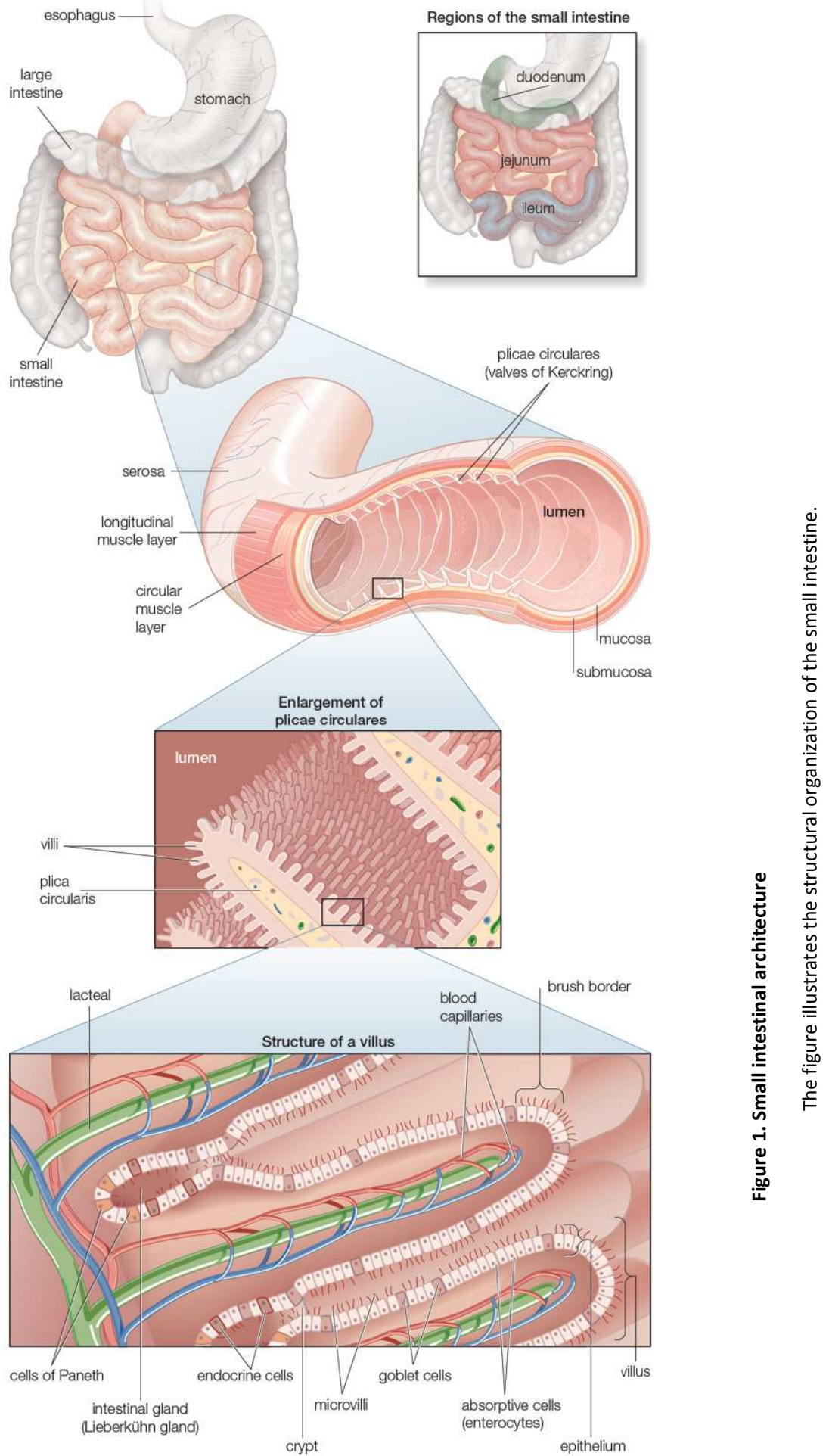
The lining of the small intestine is characterized by numerous finger-like protrusions called villi. The epithelium covering the mucosa consists of many different cell types with specialized functions. Enterocytes are the most abundant cell type and mediate the absorption of nutrients. Their luminal surface is covered with microvilli that increase the surface area of the cells and help to increase their absorptive ability. Scattered along the epithelium are also mucus-secreting goblet cells and at the base of the cryps, Paneth cells. The Paneth cells prevent bacterial proliferation by releasing anti-microbial factors like defensis, TNF $\alpha$, lysozyme and phospholipases. Enteroendocrine cells are also found throughout the epithelium releasing gastrointestinal hormones like secretin, neurotensin and somatostatin in response to changes in the microenvironment.

The polarized, single cell layer that lines the inner surface of the small intestine consists of villus epithelium (VE) and follicle-associated epithelium (FAE). Briefly, the FAE specifically covers the Peyer's patches in the intestine and is specialized in uptake of antigen and bacteria for immune-sampling. Peyer's patches are organized lymphoid follicles that are spread throughout the human small intestine ${ }^{6}$. The follicles consist of $B$ cell germinal centers and marginal zones with proliferating $B$ lymphocytes and macrophages. The area in between the FAE and the follicle is referred to the subepithelial dome and contains $T$ cells, B cells, dendritic cells, macrophages and monocytes ${ }^{7}$. The FAE contains about $10 \%$ membranous (M) cells that have irregular microvilli structure and less microvilli than regular VE enterocytes ${ }^{8}$. Simplified, the VE is specialized in nutrient uptake and consists of the cell types described above, while the FAE and $M$ cells are specialized in antigen sampling and transport to the underlying follicle? .

The main function of the large intestine is absorption of electrolytes and water along with removal of undigested food and waste. Here the mucosa is arranged in crypts, where numerous strait tubular glands are present and it does not have the same villus structure as the small intestine. Still, colonic epithelium contains the same cell types as the small intestine but to a different extent. The enterocytes express shorter microvilli than those seen in enterocytes of the small intestine, with glycocalyx absent of digestive enzymes. Paneth cells and enteroendocrine cells are less abundant in the large intestine while Goblet cells are more common. Goblet cells are usually found in the crypts and their number increases distally towards the rectum. Colonic $M$ cells like cells can be found in epithelium covering colonic lymphoid follicle ${ }^{10}$.

The gastrointestinal tract is connected to the brain via a bidirectional communication system. The communication between the gut and the brain is referred to as the gut-brain axis, or brain-gut axis depending on the origin or field of focus. The brain-gut axis is comprised of neural pathways such as the enteric nervous system, vagus, sympathetic and spinal nerves. It also includes humoral pathways which comprises cytokines, hormones and neuropeptides as signaling molecules ${ }^{11}$. Traditionally researchers were focused on the psychological status 
affecting the function of the intestine, however recent studies show that the gut microbiota communicates with the brain ${ }^{12}$.

\section{Intestinal immunology}

The gut mucosal immune system is the largest immune organ in the body, contains more than $10^{12}$ lymphocytes and produces more IgA than any other site ${ }^{13}$. The gut-associated lymphoid tissues include Peyer's patches, mesenteric lymph nodes and a large number of cells spread out throughout the lamina propria and within the epithelium. Besides serving as the first line of defense against luminal antigens, the gut-associated lymphoid tissues are capable of modulating the epithelial function ${ }^{14}$. In addition to maintaining a physical barrier, the intestine is actively involved in immune surveillance at the Peyer's patch lymphoid follicles $^{15}$. M cells samples particles and bacteria from the lumen and transfer them to the underlying lymphocytes. Dendritic cells are also capable of directly sampling luminal bacteria by extending their dendrites between epithelial cells via the tight junctions ${ }^{16}$. It is an imperative for the lymphoid tissue to distinguish between pathogens and normal microflora. Under physiological conditions, lymphocytes sample antigens and travel to immune competent sites where they induce $T$ regulatory responses ${ }^{17}$. Pathogens are distinguished from commensal bacteria by pathogen-associated molecular pattern receptors found on antigen presenting cells such as epithelial cells, dendritic cells and macrophages ${ }^{18}$.

\section{Intestinal microbiota}

The human microflora or "microbiota" include bacteria, fungi, bacteriophages and viruses on or in the human body ${ }^{19}$. The human intestinal microbiota changes during our lifespan. We are born germfree and the first colonization occurs at birth and the first feeding ${ }^{20}$. After the first two-three years the microbiota becomes more stable but will continue to change under the influence of age, immune maturation, nutritional and environmental factors ${ }^{19,21}$.

The bacterial content of the adult gut is about 1-2 kilograms, include around one thousand different species and more than 15000 different strains of bacteria ${ }^{19,21}$. The total amount of bacterial cells in the human body is around $10^{14}$, which is ten times the number of human cells in the body ${ }^{22}$. The microbiota density and diversity increases from the stomach to the colon $^{23}$. The most abundant phyla in the human gut are Firmicutes and Bacteroidetes phyla $^{24}$, but also Archaea ${ }^{25}$ and Eukarya ${ }^{26}$.

Our intestinal microbiota help increase our metabolic capacity by metabolizing otherwise indigestible polysaccharides and producing essential vitamins ${ }^{27}$. It also regulate development of intestinal villus vascular architecture ${ }^{28}$, maturation of the gastrointestinal tract ${ }^{29}$ and development of immune response $\mathrm{s}^{30}$. It has also been shown that gut microbiota modulates adiposity ${ }^{31}$ and bone mass ${ }^{32}$ in mice. 


\section{Intestinal barrier function}

The intestinal barrier serves two critical functions: It enables controlled nutrient absorption and defends the body from potentially dangerous substances ${ }^{33}$. Under normal conditions the intestinal barrier allows small amounts of antigens to pass the mucosa and interact with the immune system. The balance in regulating the barrier is crucial to maintain normal nutrient uptake and a balanced antigen sampling. Many factors can alter this balance: gut microbiota modifications, mucus layer alterations, and epithelial damage can increase intestinal permeability, allowing the translocation of luminal content to the inner layer of intestinal wall ${ }^{34}$. If the control of the barrier function is disturbed the consequences may damage the mucosa and lead to pathological conditions ${ }^{33}$.

\section{Stress}

Stress is a normal component of life and adequate responses to different stressful situations are required for survival. However, there are large individual variations in the possibility to cope with stressful events ${ }^{35}$. Stress has been defined as a disruption of homeostasis, which may be triggered by a physical or psychological stimulus that produces mental and physiological reactions that might lead to illness ${ }^{36}$.

The physiological response to stress consists of a rapid and a slower component ${ }^{37}$. The rapid response is the activation of the sympathetic nervous system, which increases levels of circulating norepinephrine and epinephrine. This is referred to as the "sympathetic-adrenomedullary system" ${ }^{38}$. The slower but longer-lasting response is the activation of the hypothalamic pituary adrenocortical (HPA) axis that begins with the release of corticotropin releasing factor (CRF) from hypothalamus into the circulation. CRF then stimulates the pituitary release of adrenocorticotropic hormone (ACTH) into the bloodstream. Released ACTH increase the discharge of glucocorticoids from the adrenal cortex ${ }^{39}$. Once the stressor has ended the glucocorticoids act via negative feedback on the pituitary gland, hypothalamus, hippocampus and prefrontal cortex to reduce further production and release of CRF and $\mathrm{ACTH}^{39}$. The physiological consequences include peripheral vasoconstriction, increased heart rate and increased energy mobilization ${ }^{40}$.

\section{Stress and intestinal barrier function}

In animal models both chronic and acute stress affects intestinal barrier function via mast cells ${ }^{41}$. During chronic stress in rodents, the adhesion and uptake of antigen and bacteria in the mucosa are increased, which leads to accumulation of mast cells and microscopic inflammation $^{42}$. Barreau et al. showed that neonatal maternal deprivation of rats induces closer association of colonic mast cells with nerves, which is similar to that seen in IBS patients $^{43}$. In humans the association between stress and decreased barrier function is not as well studied as in animals. It is known that psychological stress affects the ion secretion in humans ${ }^{44}$ and it is known that severe stress episodes are an important risk factor for the development and reactivation intestinal inflammation ${ }^{45}$. In patients with inflammatory bowel disease (IBD) there is a significant association between acute daily stress and bowel symptoms ${ }^{46}$. For irritable bowel symptom (IBS) patients stressful life events increase the risk 
of developing post-infectious IBS and a relation between stress and symptom severity is noticeable ${ }^{47}$.

\section{Vasoactive Intestinal Peptide and intestinal barrier function}

Vasoactive intestinal peptide (VIP) behaves like a non-adrenergic, non-cholinergic inhibitory neurotransmitter in the small intestine ${ }^{48}$ and directly innervates the intestinal epithelium and regulates ion and fluid secretion ${ }^{49,50}$. VIP and the pituitary adenylate cyclase-activating polypeptides (PACAPs) share $68 \%$ homology and belong to the secretin peptide family. The physiological actions of these peptides are produced through activation of three common Gprotein-coupled receptors (VPAC1, VPAC2 and PAC1R), which stimulate the adenylate cyclase and increase intracellular cAMP, calcium and phospholipase $D^{51}$. Several studies have also suggested the involvement of VIP in the regulation of intestinal epithelial barrier homeostasis ${ }^{52}$ and paracellular permeability ${ }^{53,54}$. Also, numerous studies have demonstrated the importance of VIP in inflammation ${ }^{55-57}$. There are, however, very few articles regarding the involvement of VIP in intestinal barrier function during stress. Increased VIP levels have been demonstrated in mouse ileum after acute stress $^{58}$, but there are no studies regarding VIP and FAE permeability. Studies of VIP expression on or in connection to intestinal mast cells in the intestine were lacking at the start of this PhD-project.

\section{Apical junctional complex}

The junctional complexes that connect the enterocytes are important components of the intestinal homeostasis. The paracellular space between each cell needs to be tightly regulated to avoid leakage or influx of antigens. The junctional complexes consist of several groups of multi-protein structures, the tight junctions (TJs), adherens junctions, desmosomes and gap junctions. All apical junctions help hold the enterocytes together and regulate the paracellular permeability. The TJs are the major regulatory unit of the epithelial barrier and is located closest to the intestinal lumen, as illustrated in figure 2.

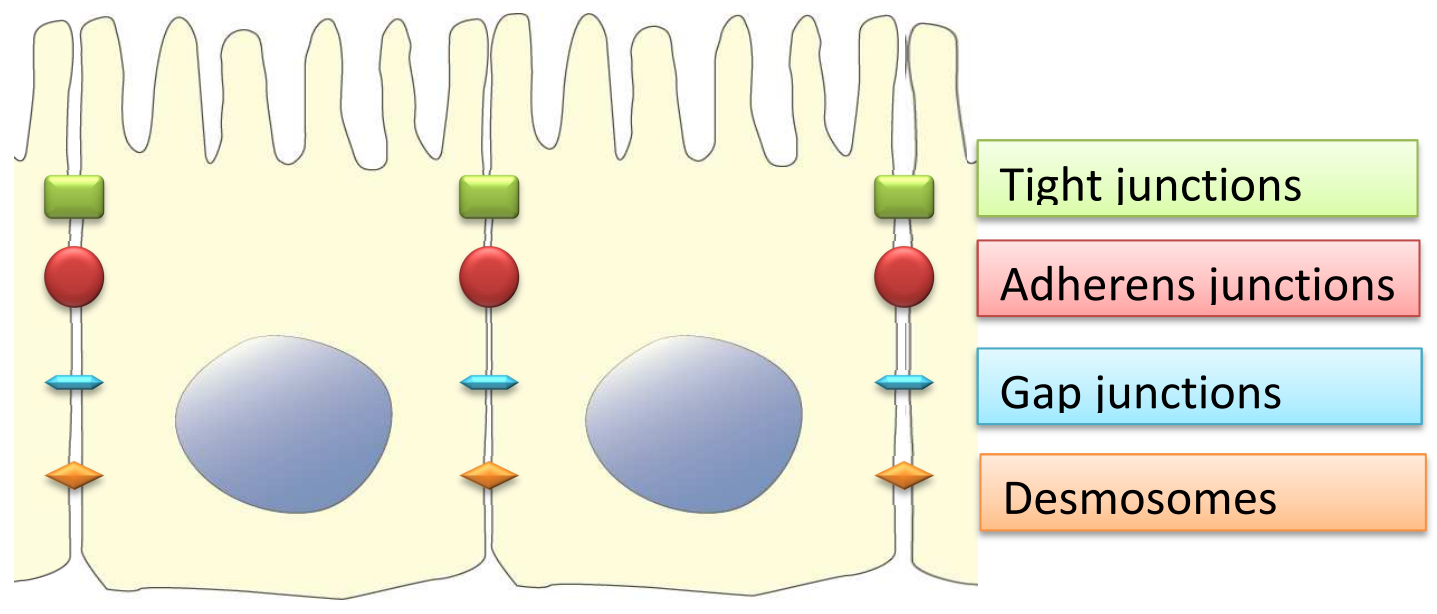

Figure 2. Junctional complexes

The figure illustrates the localization of the different groups of junctional complexes 


\section{Tight junctions}

The most important integral components of the TJs are occludin, claudins, junctional adhesion molecule (JAM) and tricellulin ${ }^{59}$. The TJs are closely associated with the zonula occludens (ZO) and cingulin proteins, which are macromolecules at the intracellular part of the tight junctional plaque. TJs are imperative for the establishment and stability of epithelial barriers ${ }^{60}$. They mediate cell-cell adhesion and thereby create a mechanical and charged barrier for selective permeability of macromolecules and ions. The transmembrane components of TJs achieve membrane polarity by blockage of the circulation and mixing of proteins and lipids along the cell membrane ${ }^{61}$. TJs interact with the actin cytoskeleton and are directly or indirectly related to the adherens ${ }^{62}$ and gap junctions. ${ }^{63}$ The intracellular components can also act as sensors for extracellular events by triggering a variety of signaling pathways and communicating these to the cell nucleus. TJs are furthermore regulated both from intracellular and extracellular events. Intracellular events that may influence TJ stability are related to energy depletion and cyclic adenosine monophosphate (cAMP) level changes. Adenosine-5'-triphosphate (ATP) depletion down-regulates TJs ${ }^{64}$, while cAMP induces an increase in the transepithelial resistance and a reduction in the paracellular permeability ${ }^{65}$. Extracellular events that can alter TJ regulation are for instance:

- Direct interaction of TJ proteins with proteins of other cells - e.g. leucocyte membrane antigens that induce site-specific TJ dissociation ${ }^{66}$.

- Direct interactions with external toxins - e.g. Claudin 3, 4 and occludin are receptors for Clostridium perfringens enterotoxin ${ }^{67}$.

- Indirect paracellular effects and hormone stimuli - e.g proteases ${ }^{68}$, interleukins ${ }^{66}$, interferons ${ }^{69}$, leukotrienes ${ }^{70}$ and growth factors ${ }^{65}$.

There is growing evidence that alterations in TJ expression and composition are associated with several different gastrointestinal diseases. Specifically, changes have been observed in celiac disease ${ }^{71}, \mathrm{IBS}^{72,73}$ and $\mathrm{IBD}^{71,74}$. Moreover, how several inflammatory mediators involved in IBD may affect TJ permeability has recently been reviewed by Suzuki et $a l^{75}$.

Experimental and clinical studies also suggest, that psychological stress exerts negative effects on intestinal TJs and increases gut permeability in IBS and IBD ${ }^{44}$, which is further discussed later.

\section{Adherens junctions}

Adherens junctions are located under the TJs and are formed by adhesion molecules of the $\mathrm{Ca}^{2+}$ dependent $\mathrm{E}$-cadherin family and their cytoplasmic binding partners $\alpha-, \beta$ - and $\gamma^{-}$ catenins. They are defined as cell junctions whose cytoplasmic part is linked to the actin cytoskeleton. The cadherins form homodimers with cadherins on adjacent cells and is in turn anchored to the actin cytoskeleton of the cell by $\alpha$-catenin. The adherens junctions are important for cell-cell adhesion and integral parts in the maintenance of epithelial integrity $^{76}$. 


\section{Desmosomes}

The desmosomes are spot-like adhesions randomly arranged on the lateral sides of plasma membranes but usually below the adherens junctions. The cell adhesion proteins of the desmosome are also members of the cadherin family of cell adhesion proteins. It consists of an extracellular core domain, outer and inner dense plaques. The inner one attaches the desmosome complex to cytoskeletal intermediate filaments. Desmosome assembly is regulated by calcium, kinase/phosphatase activity, proteolytic activity and cross-talk with adherens junctions. The primary function of desmosomes is a strong intercellular adhesion also known as hyperadhesion, but they also have signaling functions and are important in tissue development and remodeling. ${ }^{77}$

\section{Gap junctions}

Gap Junctions consist of six connexins that associate with each other and form a connexon hemichannel. The connexons, once fused with the plasma membrane, create intercellular channels with connexons on neighboring cells. Thereby they link the cytoplasm of two cells and provide a way of exchanging ions, second messengers, e.g. CAMP and cyclic guanosine monophosphate (cGMP)) and small metabolites, allowing electrical and biochemical coupling between cells. Gap junctional communication is important for cell differentiation, growth and metabolic coordination. ${ }^{78,79}$

\section{Active uptake and epithelial transport}

Endocytosis is the process by which cells internalize extracellular molecules and particles, such as proteins or bacteria, but they thereby also drink liquids and solutes. All cells use endocytosis to absorb molecules that cannot pass through the hydrophobic cell membrane. Most in vivo studies of epithelial endocytosis have been conducted on small intestinal villous and follicle associated epithelium. The endocytosis pathways are subdivided depending on the mechanisms involved in each process and are described further below (Figure 3).

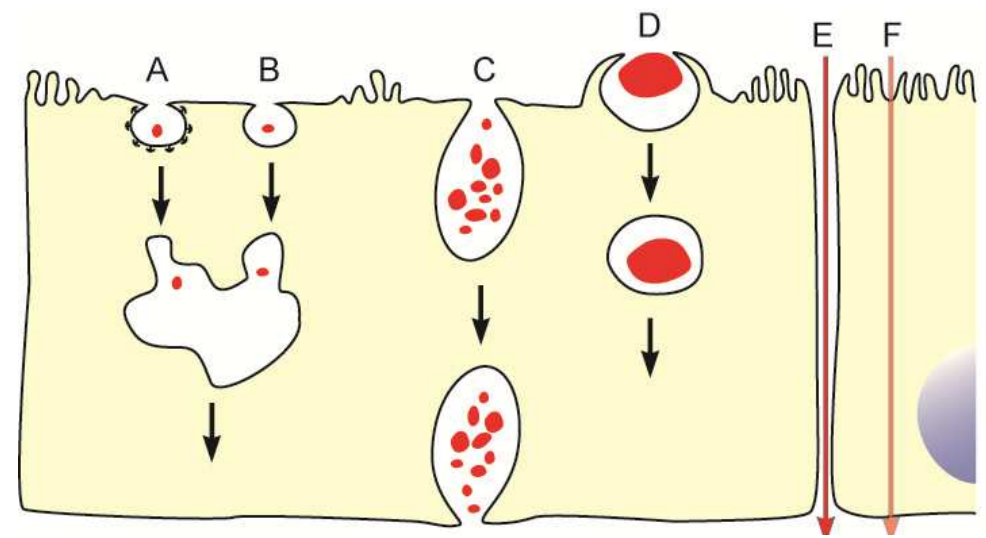

Figure 3. Cell endocytosis and passage

The figure illustrates different processes of internalization and passage. A) Clathrin- /Caveola-mediated uptake. B) Clathrin and caveolin- independent uptake. C) Macropinocytocis. D) Phagocytosis. E) Paracellular passage. F) Transcellular passage. 


\section{Clathrin- mediated endocytosis}

This type of endocytosis is a receptor-ligand mediated pinocytosis and a most studied mechanism. After binding the cargo molecule with trans-membranous high affinity receptors the complex concentrates in coated pits, which are formed by clathrins and other proteins like assembly protein 2 adaptor complexes and dynamin GTPase. The coated pit invaginates and forms a endocytic vesicle with the receptor ligand complex on the inside ${ }^{80}$. Clathrin -mediated endocytosis is used for uptake of essential nutrients and in cell homeostasis to regulate internalization of ion pumps, ion channels and also the intestinal barrier in $\mathrm{BDD}^{81}$.

\section{Caveola -mediated endocytosis}

This process involves cholesterol and sphingolipid-rich microdomains in the cell membrane. The microdomains form invaginations where many signaling molecules and membrane transporters are concentrated. Caveolin creates a coat on the invagination in the surface of the cell membrane that binds cholesterol. Inside the caveola invagination, receptors bind cargo proteins and by subsequent signaling cascades involving G-protein and kinases the invagination is internalized ${ }^{80}$. Transcellular transport of albumin and regulation of TJ proteins have been shown to occur via the caveola route ${ }^{82}$. Also, viral enterotoxins use it for amplification and viral morphogenesis ${ }^{83}$.

\section{Clathrin \& caveolin- independent endocytosis}

These mechanisms are dependent on cholesterol and require small rafts of specific lipid composition $^{80}$. The rafts diffuse freely in the cell membrane and can be captured and internalized by any endocytic vesicle. How this proceeds is not fully understood but seems to be dependent on the small $\mathrm{G}$ protein $\mathrm{cdc} 42$ and glycosylphosphatidylinositol-linked proteins but can bypass conventional rab5-positive endocytic compartments ${ }^{84,85}$. Clathrin independent endocytosis occurs in neuroendocrine cells and neurons enabling rapid recovery of membrane proteins after secretion ${ }^{86}$.

\section{Phagocytosis \& macropinocytosis}

Phagocytosis is a special form of endocytosis of solids e.g. large particles, microbes and remnants of dead cells ${ }^{87}$. Receptors for antigen uptake are expressed on the cell membrane. Fc-receptors recognize and bind antibodies bound to antigens for instance on the surface of microbes $^{88}$. A signaling cascade triggers formation of extensions or protrusions from the cell membrane engulfing the pathogen and creating a phagosome. An inflammatory response is then triggered and the phagosome fuses with degradation vesicles (lysosomes) to destroy the content of the phagosome. Fragments of the pathogen are then presented on the surface of the phagocytic cell to provoke a response from the adaptive immune response. Phagocytosis is mainly observed in macrophages, monocytes, dendritic cells and neutrophils but bacterial internalization has been shown in enterocytes ${ }^{89}$. Phagocytosis is also important for the non-specific uptake of luminal dietary and bacterial antigens and is common in $M$ cells ${ }^{90}$. 
Macropinocytosis resembles phagocytosis but is not receptor mediated and engulfs a liquid drop with its content rather than a solid particle ${ }^{88}$. Instead of extending the cell membrane to engulf, the process of macropinocytosis almost collapses onto and fuses with the cell membrane to generate a macropinosom. Colonic enterocytes, $\mathrm{M}$ cells and dendritic cells are triggered into prolonged macropinocytic activity by antigen activation ${ }^{91}$. The protein antigen horseradish peroxidase (HRP) is known to be taken up by this mechanism ${ }^{92}$ and viral antigens induce macropinocytosis in order to amplify viral uptake ${ }^{93}$.

\section{Transcytosis}

Transcytosis is the process by which various macromolecules are transported inside an endosome across the interior of the cell. Proteins in the cell membrane can either remain at the cell surface or rapidly be internalized into early endosomes, which are then transported to either apical or basolateral sorting compartments ${ }^{94}$. They can then either recycle to the cell membrane with or without releasing the endocytotic protein or merge with lysosomes, or be transported from one cell membrane to another ${ }^{94}$. Early endosomes can also be delivered to late endosomes and merge with lysosomes. The cargo is then usually degraded and the endosomal receptor proteins recycle back to the cell surface ${ }^{91}$. The operation of these transport routes requires that several sorting decisions are continuously made. These are governed by a system of sorting signals in the cargo proteins and molecular machinery that recognizes the signals and delivers the protein to their intended destination. 


\section{Mast cells}

Mast cells have traditionally been recognized as initiators of allergic diseases and have only fairly recently been shown to play fundamental roles in innate and adaptive immune responses to infection and inflammatory autoimmune diseases ${ }^{95,96}$. There is also evidence that they take part in inflammatory responses to developing tumors, which may either expedite or impede tumor growth depending on the type of cancer ${ }^{97,98}$. Mast cells are also involved in other functions such as promotion of angiogenesis, tissue remodeling and wound healing ${ }^{99,100}$. They are versatile cells that contain numerous secretory granules in the cytoplasm and are distributed throughout the body in several different tissues. For the most part mast cells are located around blood vessels and nerve endings in skin $^{101}$, gastrointestinal tract ${ }^{102}$, respiratory organs ${ }^{103}$ and to a lesser extent in the brain ${ }^{104}$. The great possibilities displayed by the mast cell in its response to different stimuli make it a truly interesting cell type that can act both positively and negatively on the host.

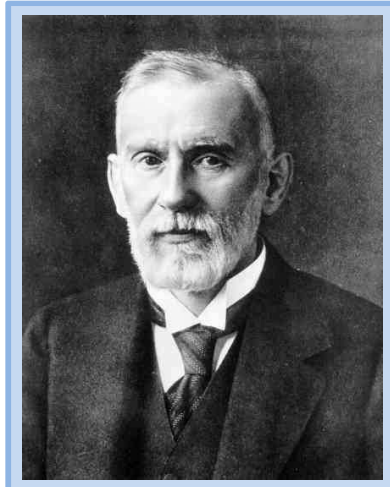

The mast cell was first described 1878 by Paul Ehrlich in his dissertation entitled "Beiträge zur Theorie und Praxis der histologischen Färbung" which translates to "Contributions to the Theory and Practice of Histological staining". When he was using aniline dye, granules of the protoplasm were stained blue. He believed the cells had a nutritional function and named them "Mastzellen" after the German word "mast" which implies a fattening or suckling function. In 1908 Ehrlich was awarded the Nobel Prize in Physiology or Medicine together with Ilya Mechnikov for their "work on immunity".

Paul Ehrlich (1854-1915)

\section{Origin and subtypes}

Mast cells are derived from hematopoietic progenitor cells in the bone marrow and mature in peripheral tissues ${ }^{105}$. Circulating human mast cell precursors are defined as being CD34+, c-kit+ and $\mathrm{CD} 13+$ cells $^{106}$. Mature mast cells are distributed throughout the body, located strategically in tissues that interface the outside world. Different types of mast cells are found depending on the influence of different microenvironments in various tissues ${ }^{107}$. Human mast cells are classified according to their granule contents. Mast cells, that contain only tryptase and resemble rodent mucosal mast cells in their distribution pattern in the mucosal layer of the gut and lungs, are referred to as MCTs in rodents. Those that resemble rodent connective tissue mast cells contain tryptase, chymase and carboxypeptidase $A$, and are mainly found in skin ${ }^{108,109}$ and referred to as MCTCs. Despite these differences it has been suggested that mast cell phenotypes are interchangeable depending on the anatomical microenvironment ${ }^{110}$. 


\section{Activation}

Mast cells are armed with a large selection of receptors, which enables them to interact with their environment. The most well-known activation of mast cells occurs by interaction of a multivalent antigen with its specific IgE antibody bound to the cell membrane via the FcERI receptor. They can however also be activated by non-IgE-related substances, like cytokines, neuropeptides, immunoglobulin-free light chains, polybasic compounds, complement components and certain drugs ${ }^{111}$ (Figure 4).

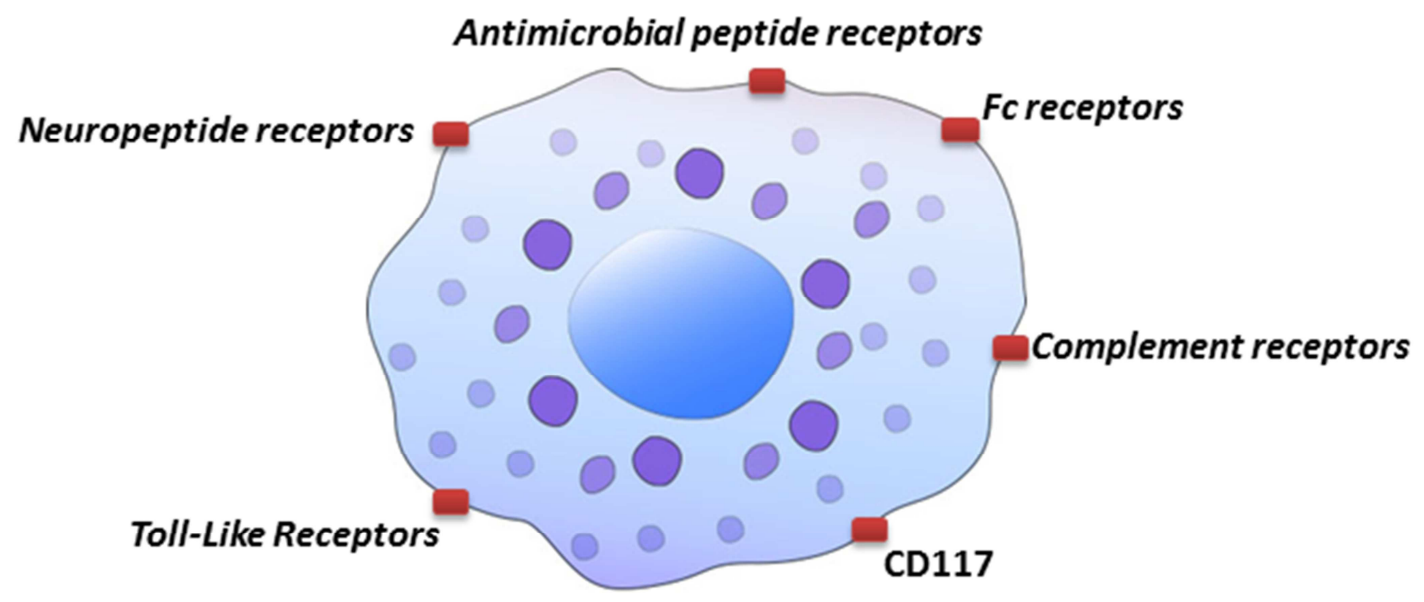

\section{Fc receptors}

Mast cells express receptors for the Fc part of both IgE and IgG antibodies. The FceRI is a high-affinity receptor for IgE and FcyRI for IgG. FcyRII and FcyRIII are low-affinity receptors for $\operatorname{IgG}^{112}$. FcعRI-mediated activation of mast cells is a well-established reaction, which has been used in studies of allergic reactions ${ }^{113,114}$. IgE can even bind the FcERI and effect mast cells without being bound to an antigen ${ }^{113}$. FcyR can only bind IgG-antigen complexes and regulate mast cell activation both positively and negatively ${ }^{115}$.

\section{Complement receptors}

The complement system includes more than 30 serum proteins and cell-surface receptors, that facilitate host defense through opsonization, chemotaxis, leukocyte activation and cell Iysis $^{116}$. Mast cells express complement receptor (CR) 3, CR4, CR5 and products of comple-

Figure 4. Examples of mast cell receptors

ment activation such as $\mathrm{C} 3 \mathrm{aR}$ and $\mathrm{C}_{5} \mathrm{aR}^{115}$. There is, however, evidence that receptor expression and response to receptor stimulation are different in mast cells depending on their anatomical location, differentiation state and cytokine environment ${ }^{117}$. 


\section{CD117}

CD117, also known as tyrosine-protein kinase Kit or c-kit is a member of the growth factor receptors with inherent tyrosine kinase activity family. CD117 activation is important for mast cell growth, differentiation and survival ${ }^{118}$. It can also induce mast cell migration through chemotaxis ${ }^{119}$. When stem cell factor (SCF), the specific ligand for kit, binds the receptor it dimerizes and initiates downstream signaling. Kit activation alone is not sufficient to induce degranulation of mast cells but it can induce cytokine production and under experimental conditions modulate mast cell degranulation and cytokine production ${ }^{120}$.

\section{Toll-Like Receptors}

Pathogen-recognizing receptors, like Toll-like receptors (TLRs), are expressed on mast cells indicating that mast cells could directly participate in host defense ${ }^{121}$. Mast cells express TLR $1,2,3,4,6$ and 9 . Each of these receptors recognizes a distinct category of microbial products. TLR2 binds to peptidoglycans, TLR3 to double-stranded RNA, TLR4 to lipopolysaccharides and bacterial DNA binds to TRL9 ${ }^{115}$. The primary response to TLR ligands is production of inflammatory cytokines rather than degranulation ${ }^{121}$.

\section{Neuropeptide receptors}

Mast cells express several different neuropeptide receptors, which belong to the $\mathrm{G}$ protein coupled receptor family. The most-studied neuropeptide is substance $P$ that acts on mast cells via the neurokinin-1 receptor $(\mathrm{NK} 1 \mathrm{R})^{122,123}$, but they also express receptors for corticotrophin releasing factor $(C R F)^{124,125}$, calcitonin gene related peptide $(C G R P)^{123}$, vasoactive intestinal polypeptide (VIP) ${ }^{122,126}$ and nerve growth factor (NGF) ${ }^{111}$.

\section{Antimicrobial peptide receptors}

Mast cells are reported to form extracellular DNA-chromatin webs, with cathelicidin LL-37 attached, that may trap and kill microbes ${ }^{127}$. In addition to their direct antimicrobial activity they also induce cytolysis by forming membrane pores and under certain conditions suppress essential microbial intracellular functions ${ }^{128}$. The antimicrobial peptides also act indirectly by augmenting innate and adaptive immune responses. One of these indirect actions is the induction of inflammatory responses through mast cells activation and recruitment of other immune cells ${ }^{123}$. Antimicrobial peptides like defensins and LL-37 stimulate mast cell chemotaxis and induce degranulation of several prostaglandins and cytokines ${ }^{129,130}$. However, the identity of the receptors is not revealed but studies have shown a dependence on phosphatidylinositide 3-kinase and protein kinase $\mathrm{C}^{129}$. 


\section{Secretion}

The activation of mast cells leads to degranulation and release of a plethora of various mediators, both preformed and newly synthetized (Figure 5).

\section{Proteases}

- Histamine

- Tryptase

- Chymase

- Carboxypeptidase

\section{Eicosanoids}

- Leukotriene $C_{4}, B_{4}$

- Prostaglandin $D_{2}, E_{2}$

Chemokines

- CCL2, CCL3, - CCL5, CXCL8

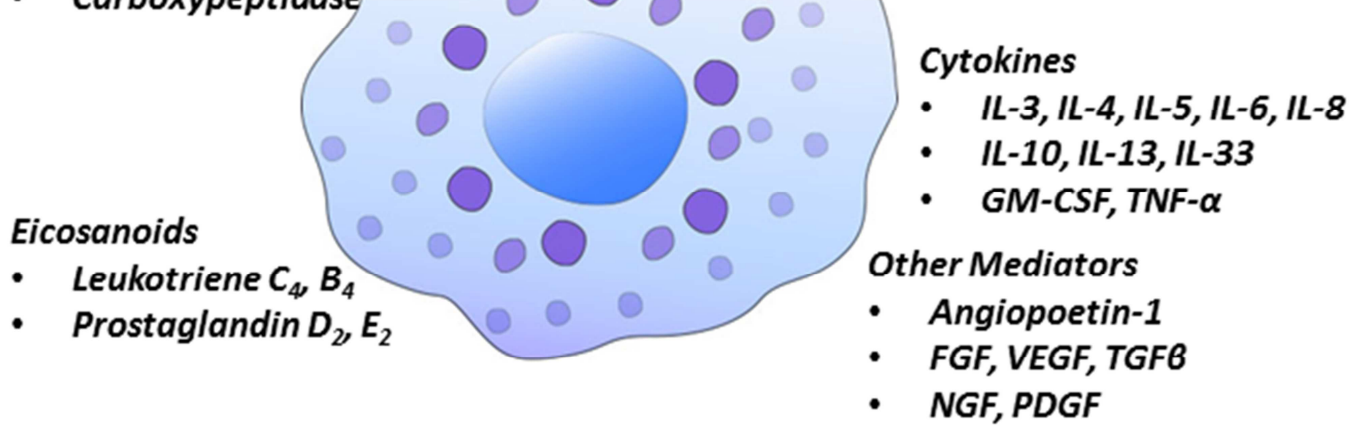

\section{Preformed mediators}

Figure 5: Mast cell degranulation

The degranulation occurs within seconds of mast cell activation and the initial phase is essentially complete within $5-10$ minutes $^{131}$. Histamine is the predominant granule mediator of acute reactions in mast cell activation, but proteases such as tryptase, chymase and carboxypepidase constitute the major components of mast cell granules ${ }^{132,133}$. Mast cell proteases constitute $30-50 \%$ of the total protein content of the cells and $\beta$-tryptase is the major protease being expressed. The protease expression is heterogeneous depending on phenotype and location in the tissue. As an example mast cells located in mucosal tissue contain primarily tryptase, while those located in skin and submucosa contain chymase and carboxypeptidase. ${ }^{132,133}$ Histamine is retained in mast cell granules by proteoglycans as heparin and chondroitin E. After secretion, histamine diffuses through the tissue and the circulatory system and exerts its effect through four histamine receptors, $\mathrm{H} 1-\mathrm{H} 4$. Histamine is rapidly inactivated by histamine $\mathrm{N}$-metyl transferase and diamine oxidase. ${ }^{134}$

\section{Eicosanoids}

The eicosanoids, leukotriene $C_{4}\left(\mathrm{LTC}_{4}\right), \mathrm{LTB}_{4}$, prostaglandin $\mathrm{D}_{2}\left(\mathrm{PGD}_{2}\right)$ and under some circumstances $\mathrm{PGE}_{2}$, are generated and released almost simultaneously with the granuleassociated mediators in mast cells ${ }^{135}$. 


\section{Cytokines and chemokines}

Mast cells generate a plethora of both cytokines and chemokines; cytokines include: IL-3, IL4, IL-5, IL-6, IL-8, IL-10, IL-13, IL-33, granulocyte-macrophage colony-stimulating factor (GM$\mathrm{CSF}$ ) and TNF $\alpha$ and chemokines $\mathrm{CCL} 2, \mathrm{CCL} 3, \mathrm{CCL} 5$ and $\mathrm{CXCL8}{ }^{108,136}$. In contrast to degranulation, the secretion of the cytokines and chemokines is a slower process taking several hours before significant levels can be detected. Although mast cells can store smaller amounts of certain cytokines like TNF $\alpha$ in their granules, the levels following mast cell activation are much higher ${ }^{137}$.

\section{Other Mediators}

Activated mast cells are also a source of angiogenic peptides and growth factors, such as angiopoietin-1, fibroblast growth factor (FGF), vascular endothelial growth factor (VEGF), tumor growth factor $\beta$ (TGF $\beta$ ), nerve growth factor (NGF), platelet-derived growth factor (PDGF) and renin $^{99,138,139}$.

\section{Function}

Mast cells are strategically located at sites of possible antigen entry and are capable guards that are equipped to participate in immune responses. Biological functions of mast cells are as described above dependent on mediators released after activation and result in recruitment of leukocytes, mucosal exudation, angiogenesis, fibrosis, activation of T lymphocytes and interaction with the nervous system ${ }^{111}$. Luminal antigens present in the gastrointestinal tract with the potential to activate mast cells are food allergens, bacteria, parasitic nematodes, invading pathogens and self-antigens.

\section{Role in immunity}

The distribution of mast cells in skin and mucosal surfaces, and their wide array of receptors place them in a prime position for detection of invading microorganisms. They have been shown to play a crucial protective role in animal models against bacterial infections in lung ${ }^{140-142}$, intestine ${ }^{143}$ and skin $^{142}$ by facilitating clearance of bacteria from these tissues or by limiting skin lesions. In some studies the protective effect was dependent on mast cell production of TNF $\alpha^{140,142}, \mathrm{IL}-6^{141}$ and leukotrienes ${ }^{144}$ as well as on recruitment of neutrophils $^{140}$ and dendritic cells ${ }^{142}$. Information on mast cell involvement during viral infections is limited, but it is known that mast cell numbers increase during pulmonary viral infections ${ }^{145}$ and cultured mast cells can be activated by viral products ${ }^{146}$. Fungi are known to exacerbate airway inflammatory disease by IgE-dependent mechanisms and has been shown to induce degranulation of mast cells in vitro ${ }^{147}$. Moreover, fungal spores potentiate IgE-dependent release from human cells obtained from bronchial lavage ${ }^{148}$. Yeast zymosan is an activator of mast cells that results in mast cell mediated peritoneal inflammation in mice $^{149}$ and release of IL-6, GM-CSF, IL-1 $\beta$ and leukotrienes but not degranulation ${ }^{150}$.

Apart from acting as first responders to microbial agents, mast cells can recruit other immune cells within lymph nodes to start the adaptive immune responses ${ }^{151}$ and promote recruitment of T cells ${ }^{152}$. Mast cell-derived TNF $\alpha$ seem to play an important role in lymph node 
hypertrophy during bacterial infection ${ }^{153}$, contact dermatitis ${ }^{154}$ and IgE crosslinking ${ }^{155}$. It is also apparent that mast cells stimulate migration of peripheral lymphocytes ${ }^{153}$, Langerhans cells ${ }^{156}$ and dendritic cells ${ }^{157}$ to regional lymph nodes thereby promoting interaction between antigen presenting cells and Thelper cells ${ }^{158}$ or activation of cytotoxic T cells ${ }^{159}$.

\section{Role in inflammation and intestinal disease}

Mast cells are most well-known for their role in IgE-mediated allergic inflammation. The focus has mainly been on the acute phase characterized by the release of mast cell mediators. The early mediators cause most of the pathology associated with allergy, including increased vascular permeability, smooth muscle contraction and induction of mucus secretion $^{112}$. It has, however, become evident that mast cell activation during allergic reactions is more complex. The reactions are currently considered to be multiphasic and include also a late phase and a chronic phase. The late phase is characterized by leucocyte infiltration at the site of inflammation and initiation of an acquired immune response, and the chronic is associated with persistent inflammation, tissue remodeling and fibrosis. ${ }^{160}$

Inflammatory bowel disease

Inflammatory bowel disease (IBD) is an idiopathic disease characterized by alternating periods of symptomatic disease and remission. Patients with IBD suffer from abdominal pain and cramps, weight loss, diarrhea, disrupted digestion and rectal bleeding. IBD can be subdivided into 2 major representatives: Crohn's disease (CD) and Ulcerative colitis (UC) ${ }^{161}$.

$C D$ and UC can be defined by the different location of the inflammation in the gastrointestinal tract and immunological and histological patterns. Briefly, CD is characterized by inflammation throughout the whole gastrointestinal tract but mainly in the terminal ileum. UC is a mucosal inflammation restricted to the colon. An increased mucosal permeability has previously been reported in both $U C^{162}$ and $C D^{163}$.

The exact etiology of IBD remains unknown but is thought to be a complex interaction of genetic, environmental and immunological factors ${ }^{164}$ (figure 6). Current investigations and observations suggest that the initial event in IBD is a result of a dysregulated immune response rather than an aggressive inflammatory response ${ }^{111,165}$.

Increased numbers of mast cells have been seen in colonic mucosa from patients with $C D$ and $U C^{166}$. Mast cell content and degranulation of TNF $\alpha$, IL6, substance $P$, histamine, prostaglandines and tryptase are also altered in IBD patients ${ }^{167}$. Smaller studies with ketotifen, a mast cell stabilizer, have shown beneficial effect in IBD ${ }^{168}$ and $U C^{169}$. In a phase II study on UC patients the tryptase inhibitor APC 2059 showed symptom improvement in more than $50 \%$ of the patients ${ }^{170}$ further strengthens the role of mast cells in IBD. 


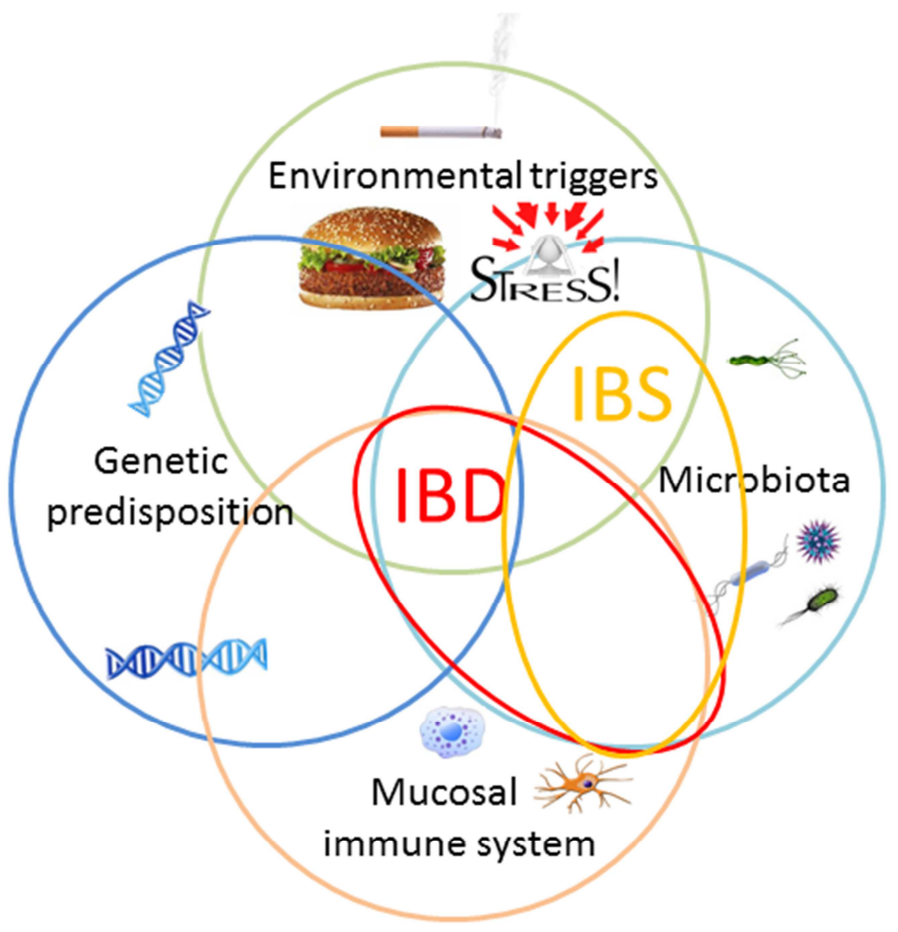

Figure 6. Pathogenesis of inflammatory bowel disease and irritable bowel syndrome

Irritable bowel syndrome

IBS is a chronic intestinal disorder often associated with abdominal pain, altered bowel motility resulting in diarrhea or constipation, and an increase in visceral hypersensitivity ${ }^{73,166,171}$. The pathogenesis of IBS is also poorly understood and defined, but implicated are psychological factors, food hypersensitivity, and gastrointestinal infections ${ }^{172-}$ 174 (Figure 6). Currently IBS is thought to be the result of dysregulation in the brain-gut axis $^{73,175}$. Stress is one of the key triggers of IBS, and both physical and psychological stressors have been associated with the pathophysiology of IBS ${ }^{44}$.

IBS patients have shown increased number of mast cells in colon and ileum ${ }^{176}$ and a positive correlation between the number of mucosal mast cells and intestinal permeability has been shown ${ }^{177}$. Additionally, an increased mucosal expression of tryptase ${ }^{178}$ and release of tryptase ${ }^{176}$ into the lumen has been described in IBS patients. The mast cell stabilizer ketotifen decreases the visceral hypersensitivity and reduces symptoms in IBS patients ${ }^{179}$. 


\section{Stress and Mast cells}

Mast cells are an integral part of the stress response system. Stress induces the release of CRF from the hypothalamus through activation of the hypothalamic-pituitary-adrenal (HPA) axis, which in turn leads to secretion of glucocorticoids that can down-regulate the immune system ${ }^{180}$. However, it is only when CRF is secreted outside of the brain by local neurons, or from immune cells, such as eosinophils ${ }^{181}$ that it exerts pro-inflammatory effects through its effects on mast cells ${ }^{182}$.

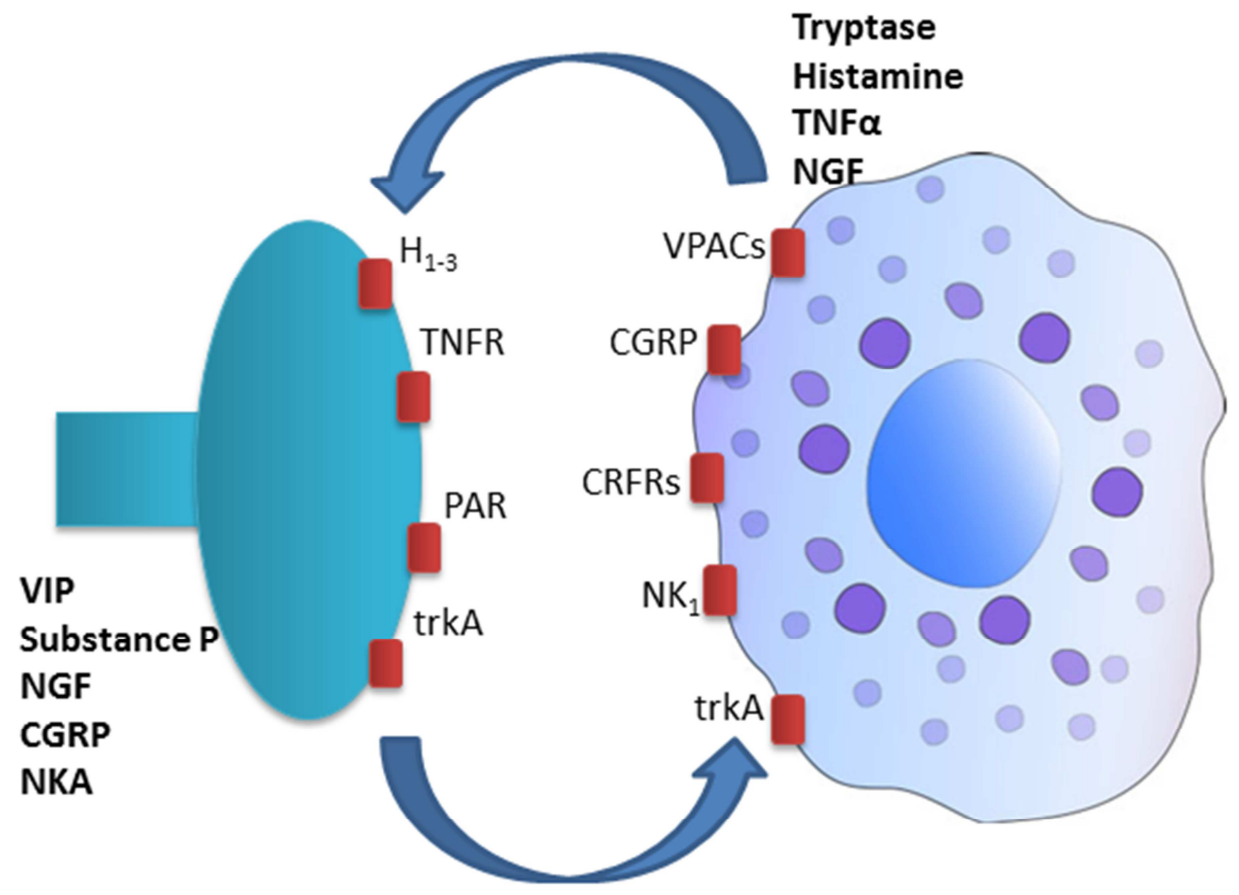

Figure 7: Mast cell nerv interactions 


\section{Probiotics}

Probiotics are according to WHO "Live microorganisms which when administered in adequate amounts confer a health benefit on the host". Today the most common probiotics are either Bifido bacteria or Lactobacilli and we can acquire them in yoghurts, where special selected strains have been added.

\section{Probiotics and intestinal barrier function}

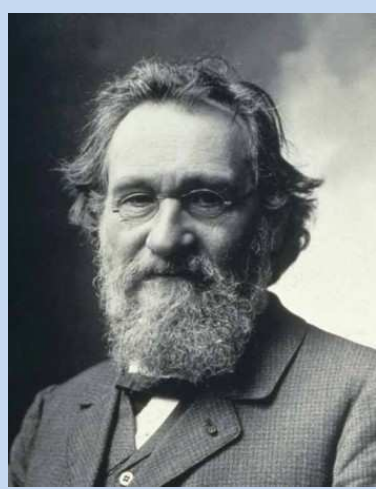

Ilya Mechnikov was a Russian scientist who shared the Nobel Prize in Physiology or Medicine with Paul Ehrlich 1908. Mechnicov observed that rural people in Bulgaria lived to very old ages despite extreme poverty and harsh conditions. He noted that their diets were rich in yoghurt and other fermented milk products which strengthened his theories on the beneficial qualities of the lactic acid bacteria produced by fermentation. Mechnikov and his colleagues began drinking sour milk to populate their own gut flora, thereby introducing the modern probiotic.

Ilya Mechnikov (1845-1916)

Several animal studies have shown significant advantages on intestinal permeability after administration of probiotics ${ }^{183-185}$. In humans, probiotics have also displayed positive effects on maintenance-treatment of pouchitis ${ }^{186}$ and of remission in $U C^{187,188}$. Several studies have displayed that the use of probiotics reduces IBS symptoms ${ }^{189,190}$. Still, there is one study where the use of probiotics have had negative effects and actually even increased mortality in severely ill, intensive care patients ${ }^{191}$. The mechanisms by which probiotics exert their effect are highly complex and to a large extent unknown. To be able to use probiotics full potential we need to further figure out the details on how they actually affect us.

\section{Peroxisome Proliferator-Activated Receptors and intestinal barrier function}

Peroxisome Proliferator-Activated Receptors (PPARs) are a group of three transcription factors originally implicated in adipocyte differentiation and glucose homeostasis. PPAR- $\gamma$, one of its isoforms, is known to exert anti-inflammatory effects by interfering with activity of inflammatory transcription factors, such as NF-KB ${ }^{192}$, activating protein-1 (AP-1) ${ }^{193}$, and signal transducer and activator of transcription (STAT) ${ }^{194}$. It is expressed in various tissues and cell types including intestinal tissue and dendritic cells ${ }^{195}$ and plays a role in regulation of intestinal inflammation. Administration of synthetic PPAR- $\gamma$ agonists reduces the production of inflammatory cytokines in dendritic cells ${ }^{196}$ and ameliorates intestinal inflammation in different experimental colitis models ${ }^{197,198}$. Up-regulation of intestinal PPAR- $\gamma$ expression occurs in response to stress signals such as LPS challenge ${ }^{199}$ or stress-induced colonic inflammation ${ }^{200}$, suggesting that the enhanced expression of PPAR- $\gamma$ in the colon may occur as an adaptive and compensatory mechanism to help down-regulate mucosal inflammation. Probiotic bacteria have been shown to affect PPAR- $\gamma$, modulating intestinal epithelial in- 
flammatory responses and barrier function ${ }^{201,202}$. For example, Ewaschuk et al. ${ }^{199}$ showed that probiotics can attenuate intestinal barrier dysfunction in mice via a PPAR- $\gamma$ dependent pathway in lipopolysaccharide (LPS)-induced sepsis. This was proved by the fact, that beneficial effects of probiotics were abolished by PPAR- $\gamma$ inhibition. However, the precise interactions between probiotics and this anti-inflammatory defense system are largely unknown.

\section{Models to study intestinal permeability}

\section{In silico}

Computer models for predicting mucosal permeability have been present since the $1980 \mathrm{~s}^{203}$. Several theoretical models have been developed to predict passive permeation characteristics ${ }^{204}$. The models are based on several statistical methodologies and a variety of computational models have been used to predict drug absorption ${ }^{204,205}$. In silico methods contribute to early pharmaceutical research and are important in target and lead discoveries. The contribution of knowledge from in silico models are predicted to increase in a foreseeable future but are at their best not as reliable as real experimental data for predicting intestinal permeability and absorption of molecules. ${ }^{206}$

\section{In vitro}

The benefits of using in vitro techniques over in vivo techniques for permeability studies include that they are less labor and cost-intensive but also because they do not involve the same ethical considerations ${ }^{207}$. Each in vitro model has its advantages and drawbacks but the main factor is how closely the model mimics the in vivo system. Cell culture models for intestinal permeability focuses mainly on passage through epithelial cell lines like Caco-2 or MDCK. Different co-culture models with the goal of more closely mimicking intestinal epithelium have been proposed. One model uses Caco- 2 and HT29 cell lines with the advantage of adding mucin-sectreting cells and thus mimicking the physiological conditions to a larger extent ${ }^{208,209}$. Another co-culture model uses Caco-2 and Raji B cells and is described in more detail under cell culture models used in this thesis. Even triple co-culture models have been presented that uses Caco-2, HT29 and Raji B cell lines ${ }^{210}$. The main disadvantage of in vitro models is that specific details are being studied and not the whole organism which might lead to results that to translate ${ }^{206}$.

\section{In situ}

Experiments for studying intestinal permeability and drug absorption involve perfusion of a marker solution into an isolated intestinal segment. The advantage of using these methods over in vitro techniques are the presence of intact blood supply and nerve interactions ${ }^{206}$. The permeability is usually assessed by measuring disappearance of marker or drug from the solution in the intestinal lumen. The presence of an intact nervous system, a blood flow and clearance capability generates a method that closely predicts in vivo conditions. These methods also provide the possibility to study permeability over a selected intestinal region. Drawbacks include disturbance of hydrodynamics due to the effect on the unstirred water 
layer and difficulties coupled to sensitivity when measuring markers or drugs with low permeability ${ }^{206}$.

\section{Ex vivo}

The ex vivo methods include experiments where excised tissue from animals or humans are the object of investigation. Examples of these techniques include intestinal perfusion loops and Ussing chamber experiments. The Ussing chamber technique has been used in the work included in this thesis and is described in greater detail under materials and methods. Briefly, the methods are used to investigate intestinal passage and transport mechanisms on live excised tissue. The advantage is that whole tissue is used, however, drawbacks include lack of blood supply and intact neural interaction.

\section{In vivo}

The advantage of in vivo techniques is that the whole organism is studied including factors like blood circulation, mucus layers, $\mathrm{pH}$ differences, gastrointestinal motility and transit time. All other methods strive to reach in vivo conditions or to predict in vivo function. Noninvasive in vivo intestinal permeability is assessed by measuring urinary excretion of orally administered substances or permeability markers. Invasive assessments include blood sampling after orally administered substances or markers. Normal markers used include polymers of polyethylene glycol, ${ }^{51} \mathrm{Cr}$-EDTA, oligo- and monosaccharides ${ }^{211}$. Animal models provide an intestinal mucosal membrane that is comparable to human ${ }^{212}$, but other species have different intestinal metabolizing enzymes, $\mathrm{pH}$, microbiota, gastrointestinal motility and transit time ${ }^{213}$. Extrapolation of animal in vivo, ex vivo and in situ findings to human therefore needs to be performed with caution ${ }^{214}$. Ethical considerations could also prove a limiting factor when performing in vivo experiments. Another potential disadvantage can be the difficulty to study isolated intestinal segments or specific mechanisms of transport across the intestinal epithelium. 


\section{AIMS}

The general aim of this thesis was to elucidate mechanisms of mast cell effects on intestinal barrier function during stress. Moreover, we wanted to determine if and how probiotics can ameliorate the mucosal barrier integrity during stress and colitis.

Specific aims for the separate studies were to:

I. Elucidate the role of vasoactive intestinal polypeptide (VIP) and mast cells in FAE permeability during stress in rats and on human intestinal barrier function.

II. Assess whether mast cells contribute to the positive effects of probiotic therapy on intestinal function in a rat model of chronic stress.

III. Study if probiotics can modulate mast cell mediator release, resulting in amelioration of corticotropin-releasing factor (CRF)-induced barrier dysfunction in vitro.

IV. Determine the effect of treatment with Faecalibacterium prausnitzii on intestinal barrier function in a dextran sodium sulphate (DSS) -induced colitis mice model. 


\section{MATERIALS \& METHODS}

\section{Ethical statement}

The studies presented in this dissertation have been conducted in accordance with the Declaration of Helsinki. Human tissue was collected from selected patients at Linköping University Hospital by employees at the department of surgery and the endoscopy unit according to specific protocols. The studies were approved by the Regional Ethical Committee, Linköping, Sweden and all donors gave their written informed consent. All animal studies were performed at Linköping University and were approved by the ethical committee on animal experiments, Linköping University, Sweden. Animal house monitoring through sentinels is performed quarterly according to FELASA standards.

\section{Patients}

In paper I, macroscopically normal specimens were taken from the terminal ileum next to the ileocaecal valve of 21 patients during surgery for colonic cancer. From five of the 21 patients, distal colonic tissue was also obtained. The patients were nine men (age 73-90, mean 78.4 years) and 12 women (age 53-88, mean 74.7 years) with no generalized disease and none had received preoperative chemotherapy or radiotherapy.

\section{Animals}

All animals were acclimatized for at least one week prior to experiments. They were kept under constant housing conditions ( 12 hour light/dark cycle, $55 \pm 5 \%$ humidity and $22 \pm 1^{\circ} \mathrm{C}$ ) and had free access to water and food throughout the experiment period. Rats were kept in pairs in $14 \mathrm{dm}^{3}$ cages $(37 \mathrm{~cm} \times 21 \mathrm{~cm} \times 18 \mathrm{~cm})$. Mice were housed three per cage in individually ventilated cages of $7 \mathrm{dm}^{3}(33 \mathrm{~cm} \times 16 \mathrm{~cm} \times 13 \mathrm{~cm})$. All cages were changed were changed weekly.

In paper I, the study group consisted of 38 male Wistar rats (B\&K Universal AB, Sollentuna, Sweden). We chose to work with this strain because of previous experience in the group of adequate and reproducible reactions to acute water avoidance stress (WAS) ${ }^{215}$. The rats weighed $150 \mathrm{~g}$ at arrival and handled daily by the same person for 2 weeks prior to experiments. Some groups of mice received intraperitoneal (i.p.) injections with VIP receptor blockers or mast cell stabilizers.

In paper II, the study group consisted in total of 64 rats (SLC Japan, Shizuoka, Japan). 32 rats were mast cell-deficient (strain Ws/Ws) and the remaining 32 were +/+ littermate controls. The strain was chosen for their mast cell deficiency, which made it possible for us to study the role of mast cells in stress-related mucosal dysfunction. Also, this choice enabled us to observe if probiotics could exert their ameliorating effect without mast cells. This group of 
rats were exposed to chronic WAS. Some groups of mice received i.p. injections with PPAR- $\gamma$ antagonist.

In paper IV, 56 female C57BL/6 mice (Scanbur BK AB, Sollentuna, Sweden). This strain of mice was chosen from previously published articles on Dextran sodium sulfate (DSS)induced colitis ${ }^{216}$. The mice received daily oral administration of supernatant from $F$. prausnitzii and control groups received only broth. One group of animals received (s.c.) injections with PPAR- $\gamma$ antagonist.

\section{Water avoidance stress}

We used water avoidance stress (WAS), since it has been shown to be a reproducible model for psychological stress, mimicking daily life stress in humans, with minimal physical stress 217. The model has previously been used in studies to assess psychological stress effects on intestinal permeability ${ }^{45,218}$. In addition to investigations on intestinal function, chronic WAS has also been widely used in psychiatric research as a model of depression ${ }^{219}$. The model can be used for both chronic and acute conditions. Prior to the experiments, all rats were handled daily by the researcher for two weeks to familiarize rats to human contact, thereby reducing the baseline stress level. During the stress period rats were placed on a platform $(\mathrm{h}=8 \mathrm{~cm}, \mathrm{~d}=6 \mathrm{~cm})$ in a plastic container $\left(\mathrm{h}=56 \mathrm{~cm}, \mathrm{~d}=50 \mathrm{~cm}\right.$ ) with $25^{\circ} \mathrm{C}$ water (water surface $1 \mathrm{~cm}$ below the platform). Control rats were left in their cages. After one hour, the faecal pellets were counted as a simple index of changes of colonic propulsive activity ${ }^{220}$. For acute experiments (Paper I) the WAS was performed during one hour on one occasion, and for chronic experiments (Paper II) during one hour per day for 10 consecutive days.

After acute stress or the final experiment during chronic stress rats were anaesthetized by isofluran inhalation. Intestinal segments were dissected and put in ice-cold Krebs buffer for further use in the lab.

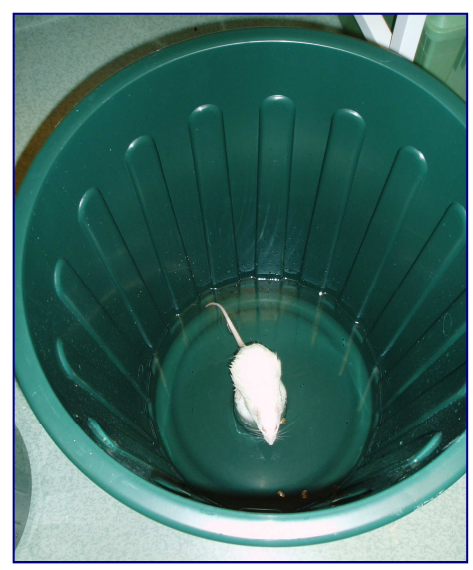

Figure 8. Rat submitted to water avoidance stress The photograph shows a rat placed on a platform surrounded by water inside a bigger container. The photo was acquired during one of the WAS experiments in paper 1. 


\section{Experimental colitis}

Chemically induced murine models of colitis are one of the most commonly used models to study IBD. The models are used because they are simple to induce and onset, duration and severity of inflammation are immediate and controllable. Both dextran sodium sulfate (DSS) and trinitrobenzene sulfonic acid (TNBS) -induced colitis are well-established animal models of mucosal inflammation ${ }^{216}$. The DSS-induced colitis model has previously been validated as a relevant model for translation of mice data to human IBD $^{221}$. Also, clinical and histopathological features of DSS-colitis reflect those seen in human IBD $^{221}$. Since different mouse strains have diverse susceptibility to DSS treatment, previously published articles ${ }^{261,262}$ gave us the advantage of knowing the concentration range of DSS to use to induce a reproducible level of colitis. We offered 3\% DSS in the drinking water ad libitum during 5 days to get an acute colitis. It is possible to use this method to get a model of chronic colitis, and then the DSS treatment is followed by a recovery period is repeated three times.

In our experiments, mice started to show symptoms after 3 days of treatment and began to recover around 5 days after the treatment had stopped. Mice were weighed and monitored daily to follow the weight change and disease progression. If the mice showed excessive weight loss or exceeded ethical morbidity thresholds they were prematurely terminated.

\section{Cell lines}

All cell lines used in this thesis are commercially available from ATCC (Manasses, VA, USA) except the Caco-2 clone 1 which was originally obtained as a kind gift from Dr. Maria Rescigno (Milan, Italy).

The Caco- 2 cell line is derived from a colon carcinoma. When cultured the cells differentiate and resemble enterocytes in the small intestine both morphologically and functionally. Caco-2 cells express TJs, microvilli, enzymes and transporters that are characteristics of small intestine enterocytes ${ }^{222}$. We used a subclone of Caco-2, clone 1 , to study barrier function of the epithelium in vitro. This subclone appeared to be the best choice when tested for its ability to differentiate to $\mathrm{M}$ cells and maintain the M-cell phenotype over time ${ }^{223}$. Caco-2 cells were cultured in high glucose Dulbecco's Modified Eagle's Medium (DMEM). Interestingly, this cell line when co-cultured with Raji B-cells generates M cell-like formation in some of the Caco-2 cells creating an epithelium similar to FAE (see further description below).

The T84 cell line is derived from a lung metastasis of a colon carcinoma in a 72 year old male. The tumor was inoculated sub-cutaneously and serially transplanted in mice until it was established in in vitro cultures ${ }^{224}$. Just as the Caco- 2 cell line this cell line grows to confluence as monolayers and exhibit TJs. We used these colon-phenotypic cells, because they reach confluence quickly and have a higher transepithelial resistance than Caco- 2 cells. The cell line was maintained in a 1:1 mixture of DMEM and Ham's F12 medium.

The rat basophilic leukemia cell line, RBL-2H3, was isolated and cloned in 1978 from Wistar rat basophilic cells, that were maintained as tumors ${ }^{225}$. The RBL cells are com- 
monly used as a histamine-releasing cell line used in inflammation, allergy and immunological research ${ }^{226}$. Moreover, they resemble mucosal mast cell in many aspects and because of good secretion of $\beta$-hexosaminidase, an easily quantifiable protease that gives a measurement of total mast cell secretion. The cell line was maintained and cultured in Eagle's minimum essential media (EMEM).

The Raji lymphoblast-like cell line was the first continuous human cell line of hematopoietic origin, established in 1963 from the left maxilla of an 11 year old Nigerian patient with Burkitt's lymphoma ${ }^{227}$. It is a B lymphocyte which was originally used in the discovery and isolation of the Epstein-Barr virus ${ }^{228}$. We used this cell line in Co-culture with the CaCo-2 clone 1 cells to establish FAE-like epithelium. It was maintained and cultured in RPMI-1640 or in DMEM during co-culture settings.

All culturing media were supplemented with $100 \mathrm{U} / \mathrm{mL}$ penicillin, $100 \mathrm{U} / \mathrm{mL}$ streptomycin and $1.5 \%(\mathrm{v} / \mathrm{v})$ HEPES (all from Invitrogen, Carlsbad, CA, USA) and 10\% heat-inactivated fetal bovine serum. Medium was changed every 2-3 days and all culturing was carried out at $37^{\circ} \mathrm{C}$ and $5 \% \mathrm{CO} 2$ in humidified incubators (95\%).

\section{Probiotic bacteria}

\section{Faecalibacterium prausnitzii}

Faecalibacterium prausnitzii (FP) was initially classified as Fusobacterium prausnitzii, however the new nomenclature was adopted in $2002^{229}$ and FP species are now considered a major representative of Firmicutes phylum, Clostridium class, Ruminococcaceae family ${ }^{230}$. The FP reference strain, A2-165, used in this paper was sequenced in 2010 and since then four additional FP species have been sequenced. Approximately $5 \%$ of the total fecal microbiota in healthy adults but consist of FP and can increase to as much as $15 \%$ in some individuals $^{231}$. The high fecal content of FP combined with its butyrate-producing capabilities ${ }^{232,233}$ strongly suggests an important function in intestinal physiological function and homeostasis since butyrate plays a major role in gut physiology ${ }^{234}$. FP has been observed to be an underrepresented species in the microbiota of CD patients and have been suggested to have anti-inflammatory effects in mice ${ }^{235}$. Culture of FP is difficult because it is considered extremely oxygen sensitive and has proven difficult to culture even under anaerobic conditions $^{231}$.

Increased intestinal permeability is common in IBD but the relationship between FP and intestinal barrier function had not been investigated. We chose to work with this strain to further evaluate FP's potential as a probiotic bacterium. FP strain A2 165 (DSM 176677, DSMZ, Braunschweig, Germany) was thus cultured anaerobically at $37^{\circ} \mathrm{C}$ in WilkensChalgren anaerobe broth according to the manufacturer's instructions. Bacterial cultures were plated to establish colony forming units (CFU) in relation to the measured optical density (OD). The supernatant was obtained after centrifugation of cultures with $10^{9}-10^{10}$ bacte$\mathrm{ria} / \mathrm{ml}(O D=1.9)$, which were frozen and then thawed directly before administration. 


\section{Ecologic ${ }^{\circledR} 825$}

The probiotic mixture Ecologic ${ }^{\odot} 825$ (Winclove Bio Industries, Amsterdam, The Netherlands) is a consist of nine viable and freeze-dried probiotic strains; Bifidobacterium bifidum (W23), Bifidobacterium infantis (W52), Bifidobacterium lactis (W51), Lactobacillus acidophilus (W22), Lactobacillus casei (W56), Lactobacillus paracasei (W20), Lactobacillus plantarum (W61), Lactobacillus salivarius (W24) and Lactococcus lactis (W19). All included strains are classified "group one" which means they have a long history of safe use and are not considered to have negligible pathogenic effects. The bacteria are able to survive in the intestine and by balancing the microbiota they are assumed to positively influence the immune system. The main feature of this mixture is the possibility to induce anti-inflammatory cytokines like IL-10 and TGF- $\beta$. Besides bacteria the mixture contains a small amount of inulin, fructo-oligosaccarides and a special mineral mixture as nutrition for the bacteria and to increase the activity after rehydration.

The probiotic mixture was rehydrated to a concentration of $10^{9} \mathrm{CFU} / \mathrm{ml}$ in sterile distilled water or in antibiotic-free medium before use.

\section{Techniques}

\section{Permeability studies}

\section{Ussing chamber}

This technique was first described in 1951 by Ussing and Zerhan ${ }^{236}$ and then modified and simplified in 1988 by Grass ${ }^{237}$. The Ussing chamber makes it possible to study animal and human intestinal mucosal function. During the experiments we can assess the electrophysiology of the tissue, passage of different permeability markers, absorption and internalization of bacteria or permeability markers. Tissue arrives to the lab in oxygenated Krebs buffer. In human and rat tissue, the external muscle layer and myenteric plexus are carefully removed and the mucosa (consisting of the epithelium, the lamina propria and the muscularis mucosae) mounted in the chamber. Mouse tissue is mounted without removal of external muscle layer and myenteric plexus. Sections of intestinal epithelium were cut to appropriate size and mounted in modified Ussing chambers (Harvard apparatus Inc. Holliston, MA, USA $)^{237}$. With different inserts made from x-ray film the exposed tissue area in the Ussing chamber can be varied. Rat tissues were mounted with inserts exposing $9.6 \mathrm{~mm}^{2}$ tissue, while mouse and human tissue had $4.9 \mathrm{~mm}^{2}$ and human biopsies had $1.8 \mathrm{~mm}^{2}$ openings. Identification and localization of FAE was performed with a dissection microscope. When mounting FAE segments the tissue was carefully adjusted so patches covered the entire exposed surface area. The mucosal compartments were filled with $1.5 \mathrm{ml}$ cold, $10 \mathrm{nM}$ mannitol Krebs buffer and the serosal compartments with $1.5 \mathrm{ml} 10 \mathrm{nM}$ glucose Krebs buffer. The chambers were kept at $37^{\circ} \mathrm{C}$ and continuously oxygenated with a mixture of $95 \%$ oxygen and $5 \%$ carbon dioxide which also stir the buffer by the turbulence created when the oxygen bubbles pass through the chamber. Tissues were equilibrated for 20-40 minutes in the chambers to achieve steady state conditions in PD. After the equilibration time they were replenished with fresh $37^{\circ} \mathrm{C}$ buffers. The potential difference (PD), short circuit current 
(Isc) and transepithelial resistance (TER) were monitored using a four electrode system with a pair of $\mathrm{Ag} / \mathrm{AgCl}$-electrodes (Radiometer, Copenhagen, Denmark) with agar-salt (3M $\mathrm{NaCl}$, $2 \%$ agar) bridges and a pair of current-giving platinum electrodes. The electrodes were coupled to a six channel electronic unit with a voltage controlled source. PD, Isc and TER were obtained as described by Karlsson et al ${ }^{238}$. Data sampling was computer controlled vi an A/D D/A converter board (LAB NB, National Instruments, USA) by a program developed in Lab View (National Instruments). Every second minute, direct pulses of 1.5, -1.5, 3, -3 and 0 $\mu \mathrm{A}$ with a duration of $235 \mathrm{~ms}$ were sent across the mucosal specimens and the voltage response was measured. In each measurement the mean voltage response of eight recordings was calculated. This procedure eliminates the influence of AC disturbances of $25-100 \mathrm{~Hz}$. A linear least-squares fit was performed of the current $(I)$-voltage $(U)$ pair relation: U=PD + TER $x$ I.

From the slope of the line, TER was obtained, and PD from the intersection of the voltage. In paper 2, tissue conductance was then calculated by inverting the TER values. All parameters were calculated during a 60 min period.

Tissue segments with a transepithelial PD higher than $-0.5 \mathrm{mV}$ were considered not viable and were discarded. At the end of the Ussing experiments, tissue viability was also assessed by adding $10 \mu \mathrm{M}$ forskolin to the apical chamber, which should raise the levels of cyclic AMP with resultant active net ion transport in viable tissue, as assessed by an increase in Isc. Non-responsive tissues were discarded.
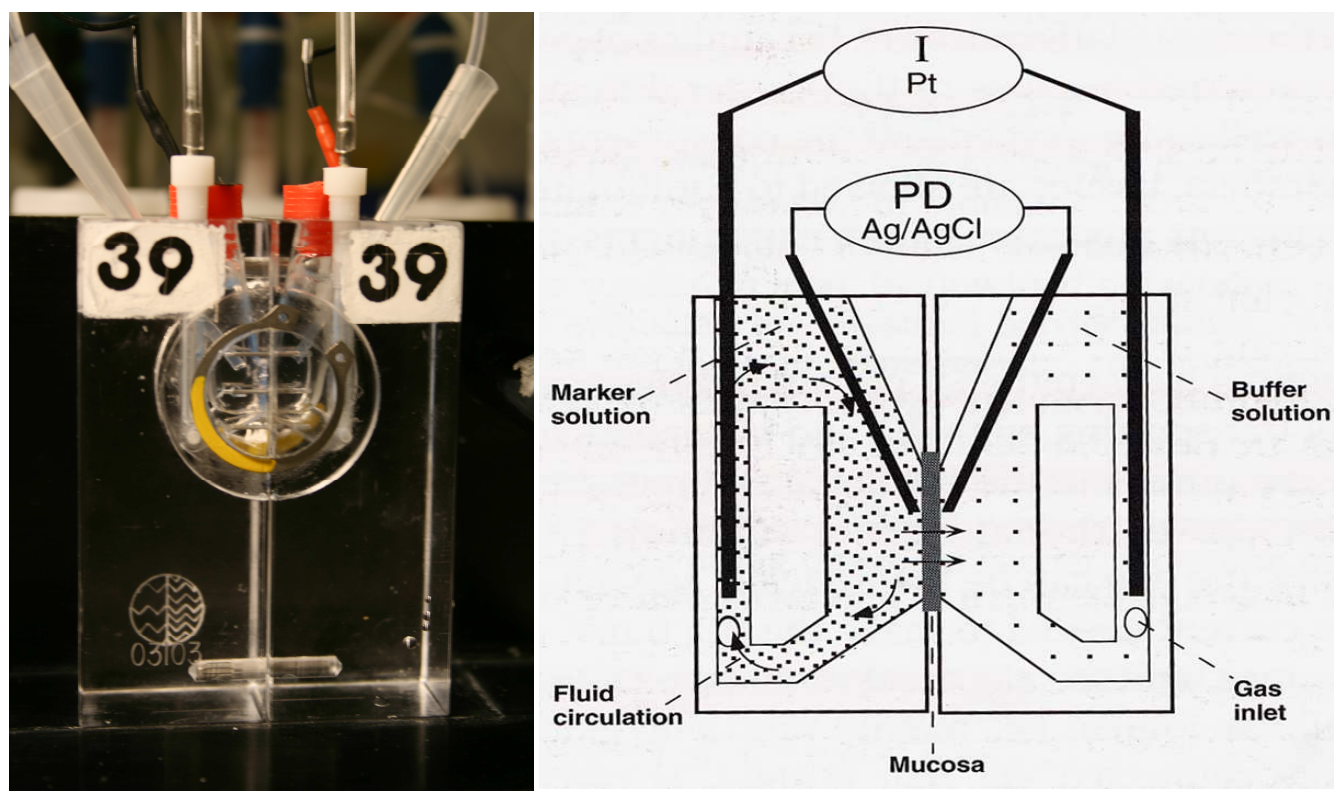

Figure 9. The Ussing chamber

On the left is a photograph of an Ussing chamber and on the right a schematic drawing of an Ussing chamber. In the figures the placement of $\mathrm{Ag} / \mathrm{AgCl}$-electrodes and platinum electrodes can be seen. The gas inlet continuously stirs and oxygenates the buffers. The tissue is carefully mounted so it covers the surface are inbetween the chamber halves. 
Experimental procedure

After mounting tissue in Ussing chambers and adding ice-cold krebs buffer, chambers are placed on a $37^{\circ} \mathrm{C}$ heating block where agar-bridges, platinum electrodes and oxygen flow is connected. The tissue is left to equilibrate and heat up for 40 minutes. Before addition of permeability markers the Krebs buffer is changed to fresh $37^{\circ} \mathrm{C}$ buffer and the first samples collected. In experiments where blockers or modulators are used, the pretreatment is most often done during the equilibration step. Sampling is done every 30 minutes, but could be different depending on which markers are used. After each sampling replacement buffer is added to compensate for the lost volume.

Permeability markers

We use several different permeability markers, each with different properties and ways to permeate the mucosa. Horseradish peroxidase (HRP) is a $45 \mathrm{kD}$ protein antigen that under normal conditions is absorbed via macropinocytosis ${ }^{92}$. Detection of permeated HRP is performed with an ELISA based analysis and uptake into mucosa is also possible to detect with electron microscopy. ${ }^{51}$ Chromuim-EDTA $\left({ }^{51} \mathrm{Cr}\right.$-EDTA) is an inert probe that we use as a paracellular marker. The strong binding of radioactive $\mathrm{Cr}$ to EDTA assures that $\mathrm{Ca}^{2+}$ cannot bind and give EDTA detergent properties. Also, the strong bond between $\mathrm{Cr}$ and EDTA provide equal passage of the molecules. Analysis of ${ }^{51} \mathrm{Cr}$-EDTA samples are done in a gamma counter. Both HRP and ${ }^{51} \mathrm{Cr}$-EDTA is widely used as permeability markers in Ussing chamber experiments. Markers are added to the mucosal side at $10^{-5} \mathrm{M} \mathrm{HRP}$ and $34 \mu \mathrm{Ci} / \mathrm{ml}{ }^{51} \mathrm{Cr}$-EDTA. Serosal samples of $300 \mu \mathrm{l}$ are collected at 0, 30, 60, 90 and 120 min after start and the volume replaced with Krebs buffer. Samples are analyzed in a gamma counter directly after the experiment and then frozen until HRP analysis is performed.

In the papers included in this thesis we also use bacteria to study intestinal barrier function. Bacteria used are the non-pathogenic E. coli strains K12 and HB101. The E. coli K12 that was used is a chemically killed FITC-conjugated bacterium that despite stopped reproduction has retained antigenicity. The other E. coli strain, HB101, is a live bacterium expressing an incorporated green fluorescent protein (GFP). Since both strains are fluorescent analysis is performed on a fluorometer. Bacteria are added to the serosal side at a concentration of $10^{8}$ $\mathrm{CFU} / \mathrm{ml}$ and normally sampled after 60 and 120 minutes.

Modulators

In the first paper, tissue was exposed to VIP, VIP receptor antagonist and mast cell stabilizer on the serosal side of the Ussing chamber. Pretreatment during 20 minutes with either $1 \mu \mathrm{M}$ VIP receptor antagonist or mast cell stabilizer ( $10 \mu \mathrm{M}$ doxantrazole in rat tissue and $1 \mu \mathrm{M}$ ketotifen in human tissue). After pretreatment $0.1 \mu \mathrm{Mol}$ VIP was added to the serosal side and the experiment started by the addition of permeability markers. Replacement buffers to compensate for lost volume during sampling contained the correct concentrations of implicated modulators. At the end of the experiment $10 \mu \mathrm{M}$ forskolin can be added to the apical 
chamber to increase levels of cAMP and resulting in an increase in Isc. Tissues that do not respond to forskolin were considered non-viable and were discarded.

\section{Cell culture models}

With the cell lines and bacteria at our disposal we were able to isolate specific cell types of interest from in vivo systems and study in vitro. The possibility to culture CaCo-2 or T84 epithelial cells on filters is a well-established in vitro model for the intestinal mucosa. In these experiments we could study passage of permeability markers and the effect of drugs, cytokines or bacterial factors under controlled conditions. Moreover, cell culture experiments also presented the possibility to co-culture epithelial cells and immune cells. We thus cocultured epithelial cell lines with mast cell lines and B-cell lines.

\section{Co-culture FAE model}

In Paper I we employed a specialized model of co-culturing. The model was used to generate FAE-like epithelia. It has previously been found by Kerneis et al. ${ }^{239}$, that co-culture of Peyer's patch lymphocytes (B-cells) and intestinal epithelial cells can trigger epithelial cell conversion into an M-cell like phenotype. Briefly, using previously described modifications $^{240-242}$, a special clone of CaCo-2 (clone 1) cells was grown on Matrigel-coated polycarbonate filters ( $3 \mu \mathrm{m}$ pore size) for 14 to 17 days. The epithelia-covered filters were then transferred to wells containing Raji B cells and maintained for 4-6 days, until $10 \% \mathrm{M}$ cell like cells were generated. CaCo- 2 clone 1 cells were also grown without Raji B cells for the same period of time, giving us the possibility to compare FAE-like cell barrier properties to normal VE barrier properties. The barrier properties of epithelial cells can then be assessed with a special volt-ohmmeter (Merck Millipore, Darmstadt, Germany) by measuring TER or by adding permeability markers on the apical side and collecting samples on the basolateral side of the cell-covered filter. To verify the conversion to FAE like epithelium several experiments was conducted. First, TER measurements confirmed $10 \%$ lower resistance in the co-culture FAE model compared to normal Caco-2 cultures as previously show by Roberts et $a l^{242}$. Second, increased transcytosis of live Salmonella typhimurium over FAE compared to normal VE has previously been described ${ }^{241}$. This were confirmed in our model as well by adding live Salmonella apically to the filters and later sampling basolateral medium for plating on agar plates. Live colonies could then be quantified on the agar plates and revealed significantly higher passage over FAE-like epithelium. Filters were also fixed and analyzed in fluorescence- and scanning electron microscopy. Fluorescence microscopy revealed that more bacteria adhered to and invaded the FAE like epithelium while scanning electron microscopy revealed cells with $\mathrm{M}$ cell-like characteristics further confirming the transformation to M cells in the model. 

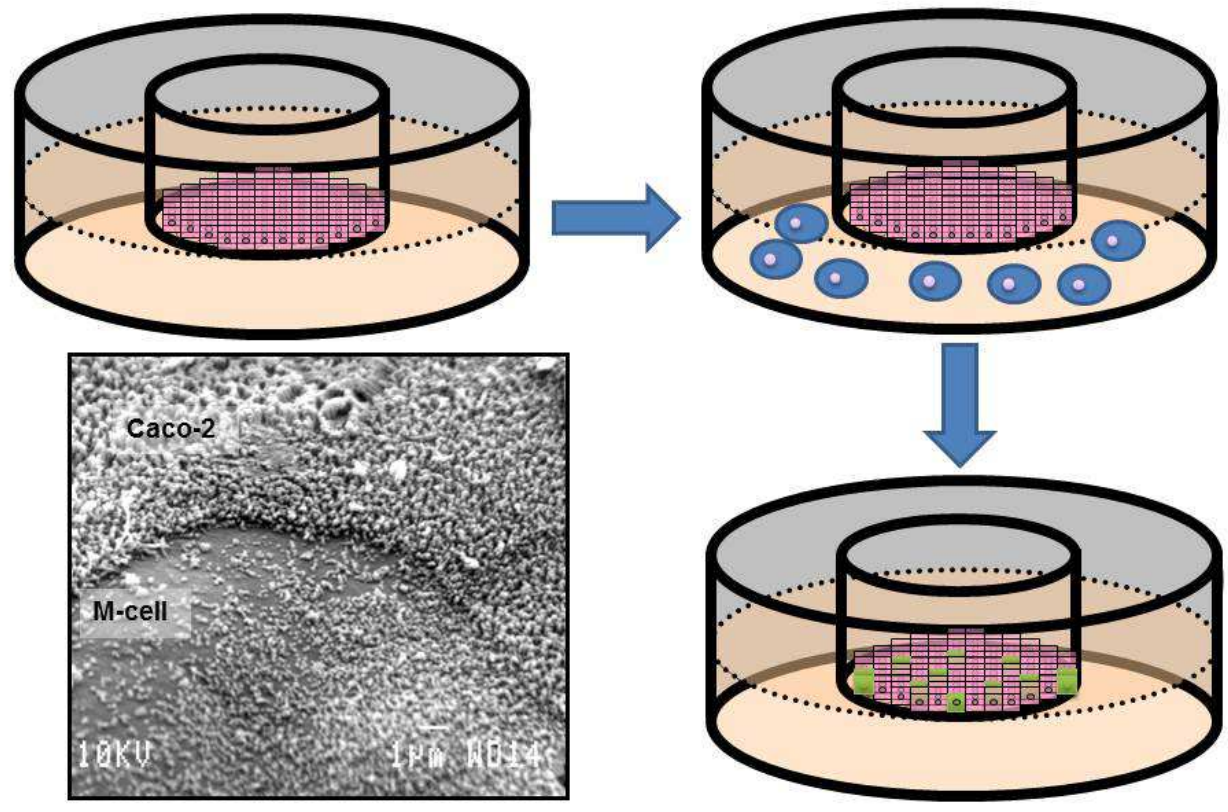

Figure 10. Co-culture FAE model

The figure illustrates the culturing steps of the FAE co-culturing model. First epithelial cells are grown on filters. Second, co-culture of B-cells and epithelial cells to induce conversion to $\mathrm{M}$ cell-like cells.

Scanning electron microscopy demonstrated the transformation of model FAE as shown by sparse irregular microvilli on the apical surface indicating the presence of $\mathrm{M}$ cell-like cells. 


\section{Co-culture epithelial cells and mast cells}

In another model of co-culturing we used the epithelial cell line T84 grown on a Transwell filter with $3 \mu \mathrm{m}$ pores. The epithelial cells were grown to confluence and then the entire filter insert was moved to a new well or plate, where we cultured a mast cell line, RBL- $2 \mathrm{H} 3$. This in vitro experimental setup gave us the possibility to isolate these cell types and study the specific effects that mast cells can have on epithelial cells, and vice versa. Measurements of barrier properties were performed as described in the section above.

In paper III we used this experimental model with T84 cells and RBL-2H3 mast cells to study the effect probiotics may have on mast cells and epithelia.

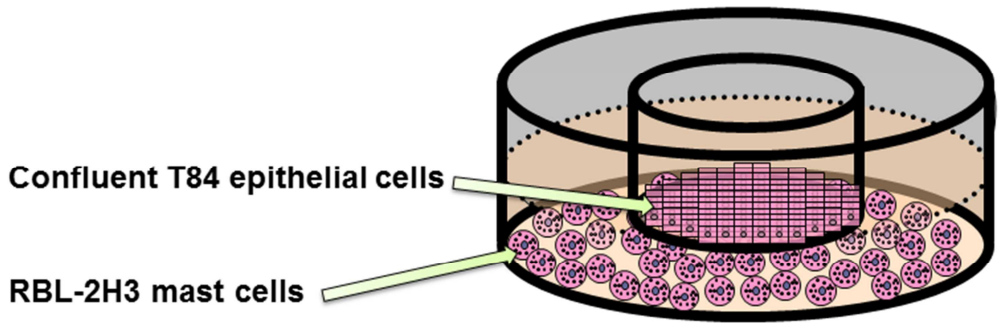

Figure 11. Co-culture of mast cells and epithelial cells

\section{Immunohistochemistry and Immunoassays}

For microscopy, primary antibodies bind to the target protein and secondary antibodies conjugated with enzymes or fluorochromes bind the primary antibody. For enzyme conjugated assays, enzyme substrate is added that gives rise to a specific color on the location where the antibodies have bound the target protein and can be visualized in normal light microscopy. Fluorochrome conjugated antibodies emits light of certain wavelengths depending on fluorochrome and are visualized with fluorescent or confocal microscopy.

Immunoassays are used to find and quantify proteins in solutions. Briefly, the bottom of a plate well is coated with antibodies directed against the target protein. The solution is added and target proteins adhere to the antibodies that are attached to the bottom. After a washing procedure a secondary set of antibodies are added that are conjugated with enzymes. Enzyme substrate is then added for a certain time and the reaction is the stopped. The solutions then change color and depending on the amount of cleaved substrate the intensity of color also changes. Analysis and quantification is performed based on light absorbance on a spectrophotometer. (Figure 12) 


\section{Immunoflourescence}

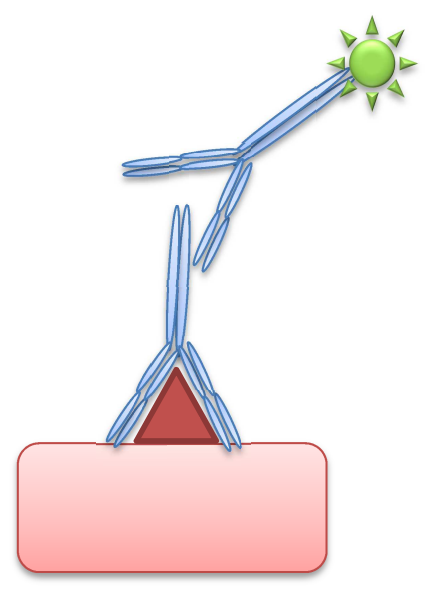

Immunohistochemistry

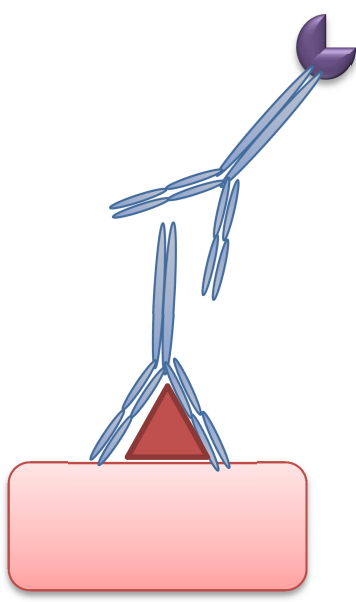

Immunoassays

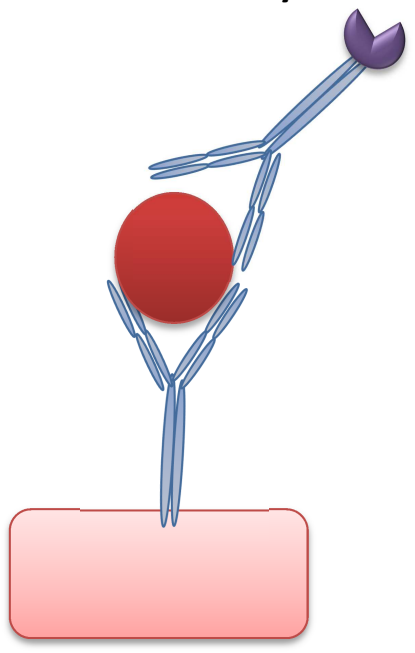

Figure 12. Immunoprocedures to identify target proteins

The figure illustrates primary antibody binding to target proteins and secondary antibodies directed against the primary antibodies. The secondary antibodies are conjugated with fluorochromes for immunofluorescence and with enzymes for immunohistochemistry and immunoassays.

In paper 1, immunohistochemistry and immunofluorescence was used to identify mast cells and to verify their VIP-receptor expression in rat and human tissue

In paper 2 analysis of Myeloperoxidase (MPO), 15-deoxy- $\Delta$ prostaglandin $J_{\mathbf{2}}\left(15 \mathrm{~d}-\mathrm{PGJ}_{2}\right)$, PPAR- $\gamma$ transcription factor and Rat mast cell proteinase (RMCPII) was performed. Briefly, all analyses were performed on tissue homogenates and analyzed with different absorbance based methods e.g. ELISA or Bradford's protein assay.

In paper 3, levels of PPAR- $\gamma$ transcription factor was performed with the same immunoassay kits as in Paper 2 but on cell lysates instead of tissue homogenates. To determine mast cell secretion the Beta-hexosaminidase release assay was used. Briefly, mast cells were stimulated and supernatant collected. The cells were then washed, lysed with a mild detergent and cell lysates was also collected. The supernatants and cell lysates was transferred to 48well plates and incubated with p-nitrophenyl $\mathrm{N}$-acetyl-beta-D-glucosamine in $0.05 \mathrm{M}$ citrate buffer $\left(\mathrm{pH} \mathrm{4.5)}\right.$ for $1 \mathrm{hr}$ at $37^{\circ} \mathrm{C}$. The reactions were then stopped by addition of $500 \mathrm{ul}$ of $0.05 \mathrm{M}$ sodium carbonate buffer $(\mathrm{pH} 10.0)$. The optical density was read and the data is expressed as percentage of released beta hexosaminidase of total.

Secretion assays of TNF $\alpha$ and $15 d-\mathrm{PGJ}_{2}$ was performed on supernatants from cell cultures and analyzed in ELISA immunoassay kits according to the manufacturer's instructions. 


\section{Microscopy}

The microscope has played a key role in the exploration of the microcosmos ever since its invention approximately 400 years ago. The use of microscopy was quite extensive in my thesis. We used it to study cells in cell culture, to determine different types of epithelium in the mucosal tissue, to identify specific proteins or adherence and passage routes of bacteria. Several different kinds of microscopy have been used in the experiments, e.g. light microscopy, fluorescence microscopy, confocal microscopy and scanning electron microscopy.

\section{Confocal laser scanning microscopy}

Confocal microscopy is an optical imaging technique used to increase optical resolution and contrast of a microscope by using point illumination and a spatial pinhole to eliminate out-of-focus light in specimens that are thicker than the focal plane. The key feature of confocal microscopy is its ability to acquire in-focus images from selected depths, a process known as optical sectioning. Images are thus acquired from different optical sections and reconstructed with a computer, allowing three-dimensional reconstructions of objects.

We used confocal microscopy when analyzing tissue stained with several fluorochromes e.g. mast cell and VIP receptors. The benefit of the optical sectioning enables increased optical resolution and contrast.

\section{Scanning electron microscopy}

A scanning electron microscope (SEM) was used in paper I for visualizing and verifying $M$ cells in the in vitro FAE model. The SEM uses a focused beam of electrons to scan a sample surface. The electrons in the beam interact with the metal coating on the sample, reflect back and are then detected. The detected signals results in a picture showing the sample topography and composition. A SEM can achieve a resolution better than 1 nanometer. $M$ cells lack the characteristic microvilli of the enterocyte and cells with that morphological feature could be seen using SEM on specimens from the in vitro FAE model (Figure 10). 


\section{Statistical analyses}

The distribution of values was tested with Kolmogorov-Smirnov test. When they displayed a symmetrical distribution they were considered parametric and further comparisons were done using Student's t-test or one-way analysis of variance (ANOVA) followed by Bonferroni's correction for multiple comparison test or Tukey's HSD test. Parametric values are presented as mean \pm SEM. Values of skewed distribution according to Kolmogorov-Smirnov test were analyzed using the Kruskal-Wallis test followed by the Mann-Whitney or Dunn's multiple comparison tests. Non-parametric values are presented as median \pm interquartile range. Throughout the thesis significance was denoted as: * when $\mathrm{P}<0.05, * *$ when $\mathrm{P}<0.01$ and *** when $P<0.001$. Statistical calculations have been performed using GraphPad Prism (GraphPad Software, San Diego, CA, USA).

\section{Methodological considerations}

\section{Ussing chambers}

Ex vivo techniques like Ussing chambers have several limitations. The limited viability of the tissue is one of the major concerns. As soon as a piece of intestine is resected it is almost as if a timer starts counting down with a limited time frame when experiments can be performed. To prolong the experimental window and get the most out of the tissue it is important to immediately put it in cold $4^{\circ} \mathrm{C}$ Krebs buffer to slow down cell deterioration, while transporting the tissue to the lab. In our experience, obtained from studies outside of this thesis, it is possible to keep tissue on ice-cold oxygenated buffer up to 1 hour with maintained ATP levels ${ }^{243,244}$. Normally the tissue is brought to our lab within 30 minutes. At the lab the external muscle of human or rat tissue is cautiously stripped from the mucosa, which is cut into appropriate-sized pieces and mounted in Ussing chambers. Our experiments rarely extended over a total of 4 hours including calibration time, but other groups have performed experiments up to 20 hours with FBS added to the Ussing chamber ${ }^{243,245}$. The technique enabled us to do experiments on tissue from human intestine and unique human patients. Moreover, human surgically resected tissue and biopsies gives us the advantage of having material from both small and large intestinal tissue, and also the possibility separate FAE from VE. However, disadvantages are the inability to control the exact region of donated tissue, possible effects of medication and the use of control tissue from non-normals. In our case, control tissue is unaffected neighboring tissue of surgical resections from cancer patients. Still, we had the option to use human biopsies instead of surgically resected tissue with the benefit of having healthy volunteers as controls. With biopsies, a small disadvantage is that we could not distinguish FAE from VE endoscopically, and we therefore had to refrain from comparing differences between the two techniques in experimental setups, where biopsies were used. We also observed a greater variation in permeability and electrophysiology in human tissue compared to animal tissue. This likely depended on a higher genetic diversity, different environmental and dietary backgrounds compared to animals, like mice and rats, which are often inbred strains living under exactly the same conditions and therefore give more consistent values. 
In our current experimental setup of Ussing chambers the resistance is measured through the whole tissue. This gives us a value consisting of the mucosal and submucosal resistance. Since we were interested in the specific transepithelial resistance and not the total tissue resistance we tried to remove as much of the subepithelium as possible to minimize the influence on the TER. We are currently upgrading our systems to use square-pulse analysis for even more adequate assessment of the epithelial resistance ${ }^{246}$.

Despite its drawbacks the Ussing chamber permits a wide range of experiments to be performed on human and animal tissue, enabling experiments that would otherwise be out of reach, ethically hard to motivate or very difficult to perform.

\section{Cell lines}

Working with cell lines gives us way to study specific cellular functions and mechanisms and to decrease the need of research animals. However, the limitations have also to be acknowledged when conclusions are drawn from the experiments. It is important to remember that cell lines are often of cancerous origin and to carefully chosen to suit ones specific needs. Moreover, they tend to change their characteristics the older they become. It is therefore important to use cells with low passage numbers. In our experiments cell cultures have been used to complement and strengthen data found in animals or to study specific details that would otherwise be difficult to address.

The epithelial cell lines used in this thesis are both similar to normal enterocytes once they have been grown to confluence. The Caco-2 clone1 cells were chosen for its ability to generate $M$ cell-like cells and the T84 because it is similar to colon epithelial cells with good TER properties. The choice of a mast cell line was harder, since there are also human mast cell lines, like HMC1 and LAD-2. However, since paper II was based on data from rats and the $\mathrm{RBL}-2 \mathrm{H} 3$ cell line is a commonly used adherent rat mast cell line with excellent secretory properties, the choice to use it was fairly simple. RBL-2H3 show many characteristics common to both mucosal mast cells and basophils. They present similar responses to LPS but diverge from either cell type in their TLR expression ${ }^{247}$. While RBL-2H3 resemble mucosal mast cells in many respects and display their basophilic lineage in others, their true nature probably lies somewhere in between. 


\section{RESULT SUMMARY}

Detailed descriptions of the results are given in the respective paper.

\section{Paper I: Vasoactive intestinal polypeptide regulates barrier function via mast cells in human intestinal follicle-associated epithelium and during stress in rats}

Rats were subjected to acute water aversion stress (WAS) to elucidate the role of VIP on mast cells during stress. Prior to stress they were injected with VIP-receptor blocker, mast cell stabilizer Doxantrazole (DOX) or $\mathrm{NaCl}$ as control. lleal tissue was then excised and used for permeability studies in Ussing chamber experiments. Rat tissue was also exposed to DOX in Ussing chamber experiments and then treated with VIP to simulate stress in vitro. Human resected tissue from non-IBD patients were also pretreated with mast cell stabilizer, Ketotifen (KETO), then exposed to VIP giving us the possibility to compare rat results to human tissue. To study the direct effect of VIP on VE and FAE we also used an in vitro FAE model on Transwell filters.

The results showed decreased stress effects in rat FAE after in vivo blocking by DOX or VIPreceptor blocker. The stress-induced increase in permeability to $E$. coli $\mathrm{K} 12$, the value under stress versus the control, was significantly decreased $(p<0.001)$ by DOX and the VIP-receptor blocker VIP 6-28 (Figure P1-1). In VE a similar pattern was seen but changes were not significant. 


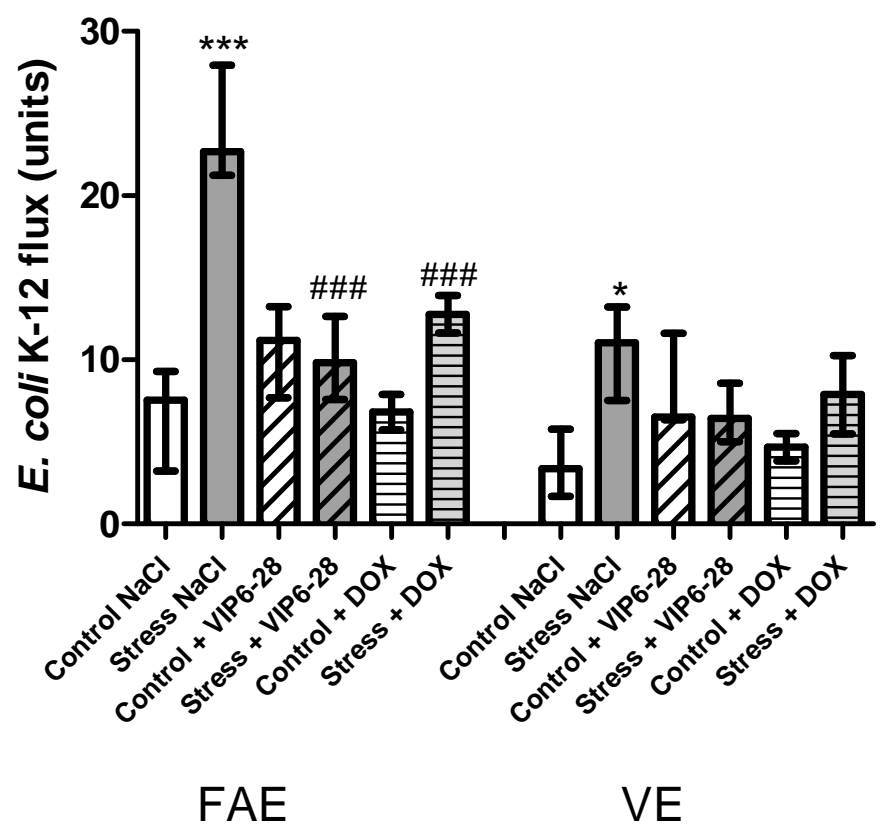

Figure P1-1. Bacterial passage in rat

Passage of Escherichia (E.) coli K-12 in rat ileal follicle-associated epithelium (FAE) and villus epithelium (VE). Passage in rats submitted to water avoidance stress, and intraperitoneally injected with vasoactive intestinal polypeptide (VIP) receptor antagonist (VIP 6- 28). Comparisons using Kruskal-Wallis showed a difference in the distributions of the groups FAE $(P=<0.0001)$ and VE $(P=<0.05)$. Further comparisons were done using MannWhitney test, ${ }^{*} \mathrm{P}<0.05,{ }^{* * *} \mathrm{P}<0.001$ compared to control, \#\#\#P $<0.001$ compared to stress or VIP. Values are presented as median \pm interquartile range, $n=4$ rats/group.

In human tissue VIP induces mast cell and VIP receptor -dependent increases in permeability in ileum but not in colon (Figure P1-2). VIP exposure in the Ussing chambers more than doubled the $E$. coli uptake in VE and FAE, increases that were significantly blocked by KETO. A similar significant decrease in bacterial passage could be seen after pretreatment with a VIP-receptor blocker. 


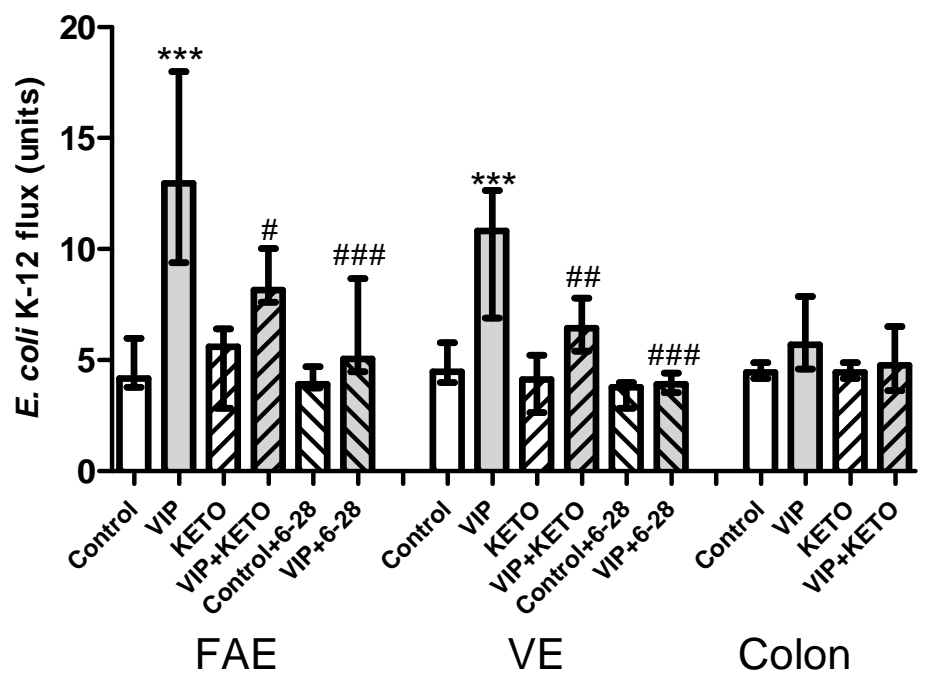

Figure P1-2. Bacterial passage in humans

Transmucosal passage of Escherichia (E.) coli K-12 in human ileum and colon. Effects of vasoactive intestinal polypeptide (VIP), ketotifen (KETO), and VIP receptor antagonist (VIP 6-28) on ileal follicle-associated epithelium (FAE), villus epithelium (VE), and colon epithelium, respectively. Comparisons using Kruskal- Wallis showed a difference in the distributions of the groups in FAE and VE $(P=<0.0001)$, but showed no difference in the colon. Further compar-

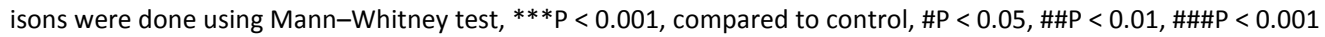
compared to VIP. Values are presented as median \pm interquartile range.

Histology of rat intestine revealed VIP-containing axons in close proximity to mast cells and VIP receptors on mast cells. On human intestine it revealed VIP-receptors on mast cells and VIP-producing cells very close to them (Figure P1-3).
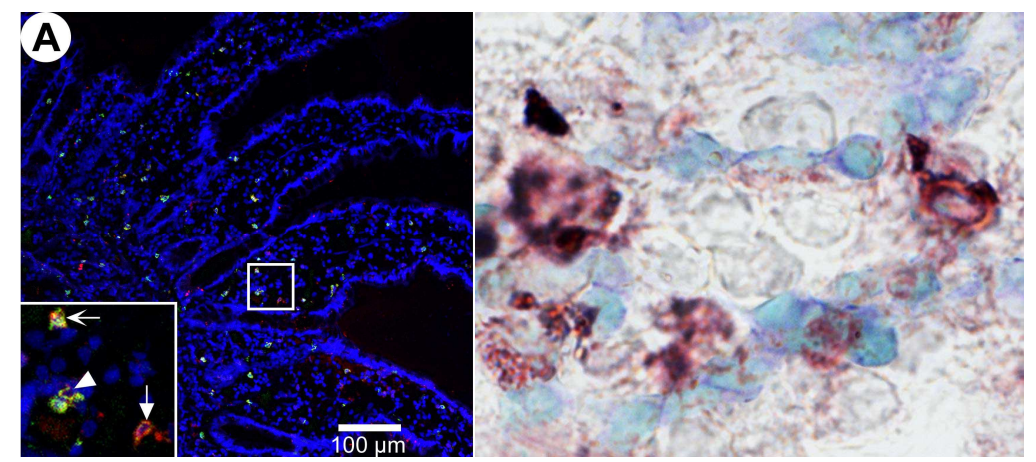

Figure P1-3. Mast cells and VIP

(A) Immunofluorescence of mast cell tryptase (MCT)(green) and vasoactive intestinal polypeptide receptors (VPAC1)(red) in villus epithelium (VE) with DAPI(blue) nuclei staining . Co-localization of mast cells and VPAC is visualized as yellow (pointed arrowheads). Mast cells expressing VPAC1/VPAC2 were situated throughout the tissues except in the follicle of the Peyer's patch. Mast cells with low or no expression of VPACs were also found as well as non-mast cells expressing VPACs. Images were acquired on a Zeiss LSM 700.

(B) Expression of vasoactive intestinal polypeptide (VIP) and mast cell tryptase (MCT) in serial sections of a human ileal Peyer's patch and overlaying follicle-associated epithelium (FAE) adjacent villi. In situ hybridization (ISH) of VIP is visualized with dark blue color and MCT is visualized in purple on this merged picture from serial sections. Images were acquired on a Nikon Eclipse E800. 
In cell culture, there was an increased number of $E$. coli HS that had translocated over the FAE-like epithelium compared to normal epithelium. Also, conditioned medium from RBL$2 \mathrm{H} 3$ mast cells stimulated with VIP significantly increased the transepithelial passage of bacteria compared to that, which had only received VIP-containing medium.

In conclusion, we found that stress-induced increase in ileal uptake of bacteria was prevented by blocking mast cells or VIP-receptors. Our findings suggest that mast cells and VIP are of importance in the way stress affects intestinal barrier function. The results may be of significance for the pathogenesis in stress-related intestinal disorders and inspire suggestions on new therapeutic approaches.

\section{Paper II: Role of mast cells and PPAR stress-induced intestinal permeability in rats}

As displayed in paper I, mast cells are major effectors of stress-induces alterations of intestinal barrier function. Probiotics have positive effects on barrier function in chronic stress, but mechanisms are largely unknown. Our aim in paper II was to study the effects of probiotics during stress and to study if a possible ameliorating effect could be mast celldependent.

Normal and mast cell deficient rats were subjected to chronic WAS to elucidate the role of probiotics on mast cells during stress. Seven days prior to WAS a probiotic mixture consisting of nine different lactic acid bacteria was added to the diet of half of the animals. To determine dependence of the PPAR- $\gamma$ pathway one group of rats receiving probiotics were also given daily injections with a specific PPAR- $\gamma$ antagonist. Animal weights were recorded daily as well as the amount of fecal pellets during the daily 1-h WAS. On the last day of stress the colon and mesenteric lymph nodes (MLNs) were harvested. Colonic tissue permeability was assessed in Ussing chambers and MLNs were cultured to determine bacterial translocation.

There was a decrease in weight and an increase in propulsive activity during the daily stress session in the stressed rats. The increased latter was ameliorated by the probiotic mixture (figure P2-1). 


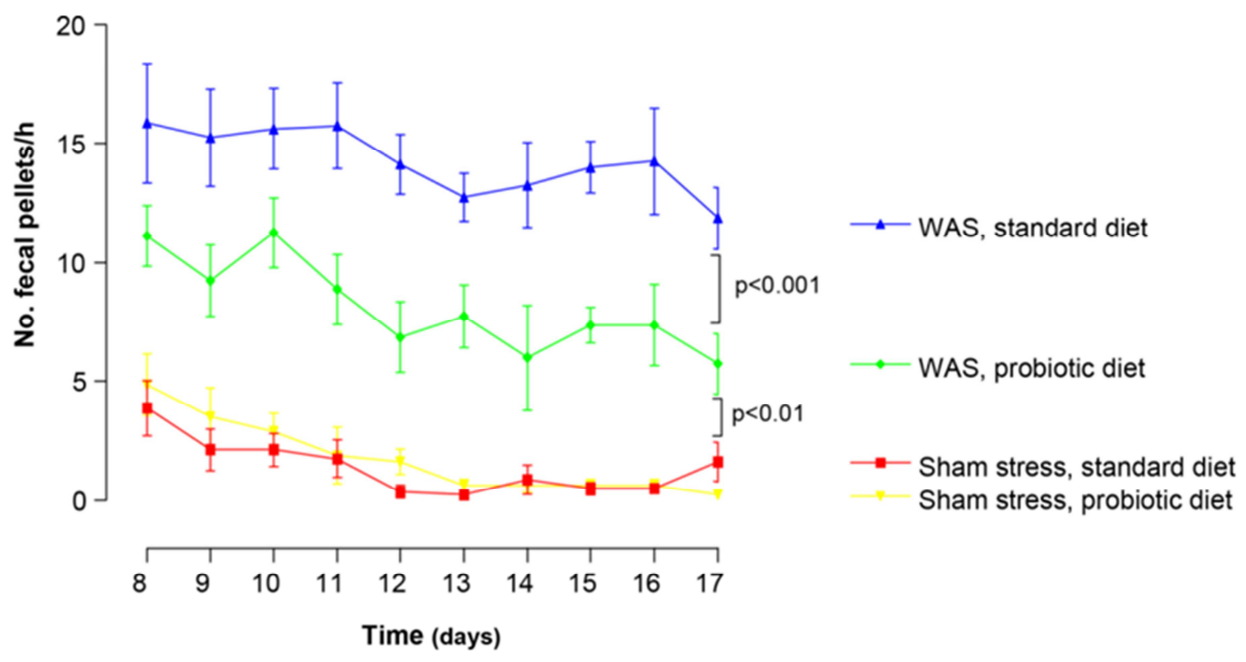

Figure P2-1. Propulsive activity in stressed rats

After seven days of standard or probiotic diet in wild type +/+ rats were subjected to water avoidance stress (WAS) or sham stress for 10 consecutive days. Graph shows quantified fecal pellet expulsion during each of the 10 stress sessions. Comparisons were performed using ANOVA followed by Tukey's HSD. $n=8$ in each group.

In wild type rats the chronic stress resulted in increased permeability to ${ }^{51} \mathrm{Cr}$-EDTA, HRP and passage of $E$. coli. Rats given probiotics had a significantly lower passage of all markers. Stressed, mast cell-deficient and probiotics-fed rats showed significantly higher passage of all permeability markers compared to wild type rats on probiotics. Wild type rats that received probiotics and daily injections with a PPAR- $\gamma$ antagonist showed the same results as mast cell-deficient (figure P2-2).
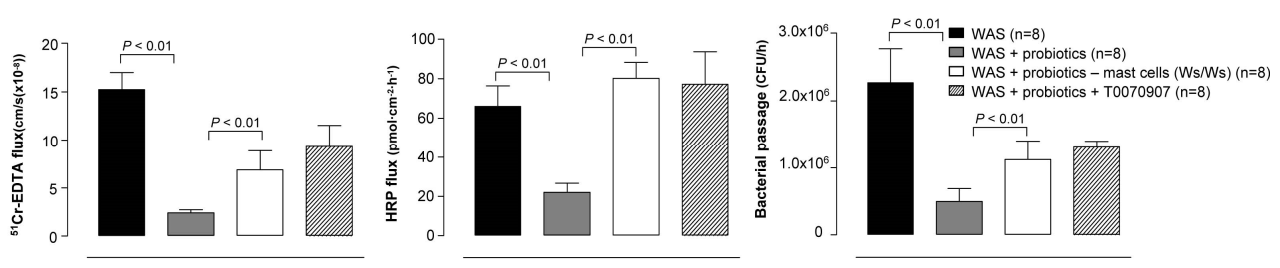

Figure P2-2. Protective effects are mast cell and PPAR- $\gamma$ dependent

Probiotic-induced barrier protective effects are mast cell and PPAR- $\gamma$ dependent. Eight mast cell deficient and 16 wild-type rats were subjected to water avoidance stress (WAS) or sham stress (SS) $1 \mathrm{hr} /$ day for 10 days. Seven days prior to the onset of stress, probiotics were added to the standard diet in all mast cell deficient and half of the wild-type animals. To determine dependence of PPAR- $\gamma$ an additional 8 WAS subjected, probiotic-fed wild-type rats were injected daily with the specific PPAR- $y$ antagonist T0070907. Colonic mucosa was mounted in Ussing chambers to determine (A) ${ }^{51} \mathrm{Cr}$-EDTA flux, (B) permeability to horseradish peroxidase (HRP) and (C) passage of live fluorescent E.coli HB 101. Graphs show mean \pm SEM. Data were collected from independently acquired sets of three tissue segments per rat. Comparisons were performed using ANOVA followed by Tukey's HSD. 
When investigating bacterial transport to MLNs, none of the sham-stressed (SS) rats, one of the stressed that received probiotic diet and all stressed rats on a standard diet had increased transport of potentially pathogenic bacteria (table below).

\begin{tabular}{|l|l|l|}
\hline Group $(\mathrm{n}=8)$ & Affected rats/rats in group & CFU median(range)/g tissue \\
\hline SS, standard diet & $0 / 8$ & 0 \\
\hline WAS, standard diet & $8 / 8$ & $1.4 \times 10^{3}\left(2.3 \times 10^{3}-2.3 * 10^{4}\right)$ \\
\hline SS, Probiotic diet & $0 / 8$ & 0 \\
\hline WAS, Probiotic diet & $1 / 8$ & $0\left(0-1.2 \times 10^{2}\right)$ \\
\hline
\end{tabular}

Probiotic diet during WAS decreased tissue myeloperoxidase (MPO) and rat mast cell proteinase II (RMCPII) activity, but increased the PPAR- $\gamma$ transcription factor and $15 \mathrm{~d}-\mathrm{PGJ} \mathrm{J}_{2}$ (Figure P2-3), compared to control rats on regular diet. Mast cell deficient probiotics fed rats showed significantly higher MPO activity and significantly lower levels of PPAR- $\psi$ transcription factor and $15 \mathrm{~d}-\mathrm{PGJ}_{2}$ compared to stressed, probiotic-fed rats.
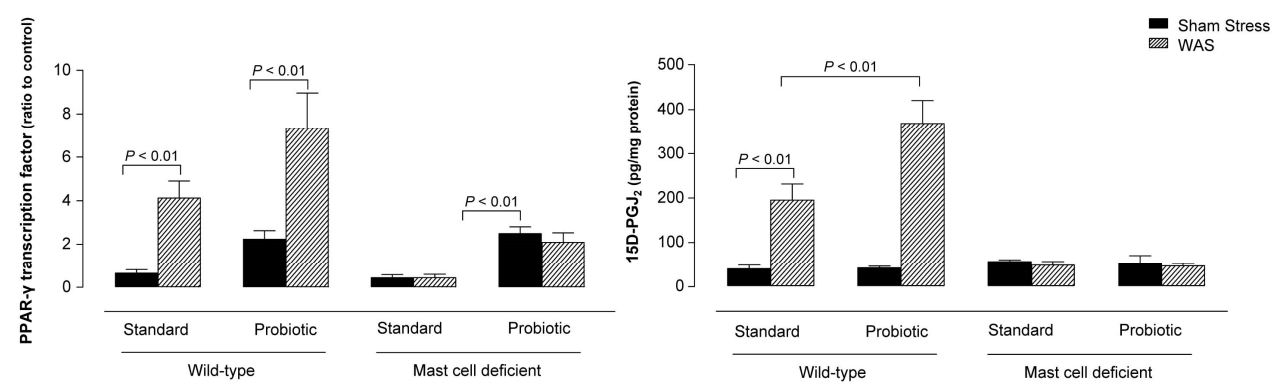

Figure P2-2. Colonic PPAR- $\gamma$ activation and 15d-PGJ2 levels

Thirty-two mast cell deficient (Ws/Ws) and 32 wild-type $(+/+)$ rats were subjected to water avoidance stress (WAS) or sham stress (SS) $1 \mathrm{hr} /$ day for 10 days. Seven days prior to the onset of stress, probiotics were added to the standard diet in half of the animals. (A) PPAR- $\gamma$ transcription factor in nuclear fractions, and (B) 15d-PGJ2 levels were determined in colonic mucosa. Graphs show means \pm SEM. Analyses were run in duplicates. Comparisons were performed using ANOVA followed by Tukey's HSD.

In conclusion, the probiotic mixture used was effective in protecting the intestine against stress-induced intestinal barrier dysfunction and mucosal inflammation. The protecting effect involves mast cells and a PPAR- $\gamma$-dependent mechanism, that was likely mediated though mast cell-derived $15 \mathrm{~d}-\mathrm{PGJ}_{2}$. These novel findings concerning the anti-inflammatory properties of probiotics could have therapeutic potential in the prevention of stress-induced gastrointestinal symptoms in IBS and decrease the number of relapses in IBD. 


\section{Paper III: Probiotics modulate mast cell degranulation and reduce stress- induced barrier dysfunction in vitro}

To further investigate the mechanisms for the effects of probiotics on mast cells, we continued our research using an in vitro model with cell lines. This gave us the benefit of isolating the role of the cell types of interest and to study the specific effects of probiotics in a controlled environment.

The rat mast cell line RBL-2H3 secretion was investigated after exposure to corticotropinreleasing factor (CRF). The same probiotic mixture as in Paper II was used to study if it influenced the mast cell secretion. Mast cell release of $\beta$-hexosaminidase, TNF $\alpha$ and $15 d-P G J_{2}$ was determined in different in vitro systems. Confluent monolayers of the T84 epithelial cell line were co-cultured with RBL-2H3 mast cells and pretreated with probiotics before addition of CRF to activate mast cells. Transepithelial resistance (TER) and microsphere permeability were measured over a 24-h period. Monolayers were also pretreated with a specific PPAR- $\gamma$ antagonist prior to treatment with probiotics to determine a role of PPAR- $\psi$.

CRF caused a dose- and time-dependent degranulation from RBLs (figure P3-1x). Pretreatment with probiotics decreased mast cell secretion of $\beta$-hexosaminidase and TNF $\alpha$, but an increase in $15 d-P G J_{2}$. No significant release of TNFa or $15 d-P G J_{2}$ could be observed when mast cells were exposed to probiotics without addition of CRF. Neither did the nonpathogenic $E$. coli $\mathrm{HB} 101$ prevent CRF-induced activation of mast cells.

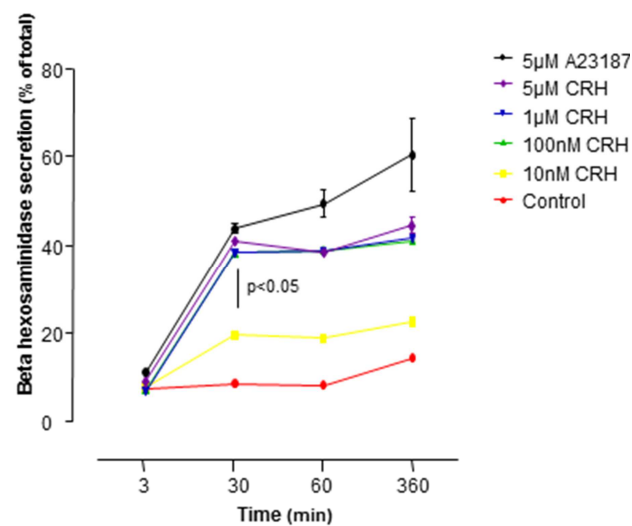

Figure P3-1. CRF induces dose dependent degranulation of RBL mast cells

Figure showing that incubation of RBL mast cells

with CRF at varying dosages $(5 \mu \mathrm{M}, 1 \mu \mathrm{M}$,

100nM, 10nM) causes a dose dependent degranulation of mast cells as shown by the release of beta hexosaminidase. Data are mean $\pm S E M ; n=6$ preparations from 2 experiments; A23187 was included as a positive control $(5 \mu \mathrm{M})$. Comparisons were performed using ANOVA followed by Tukey's HSD.

PFA-killed probiotics did not exert any inhibitory effect on mast cell degranulation. However, sterile-filtered supernatants from probiotics significantly decreased CRF-induced activation of mast cells release in a dose-dependent manner. Moreover, the release of TNF $\alpha$ decreased and $15 \mathrm{~d}-\mathrm{PGJ}_{2}$ increased in a dose dependent fashion in mast cells pre-stimulated with probiotic supernatant after exposure to CRF (figure P3-2), suggesting that a soluble factor released by live probiotics mediate the inhibitory effects on mast cell degranulation and modulation of the degranulation profile. We also examined each strain in the probiotic mixture and could observe that some bacterial strains had a higher effect on CRF-induced mast cell degranulation. 

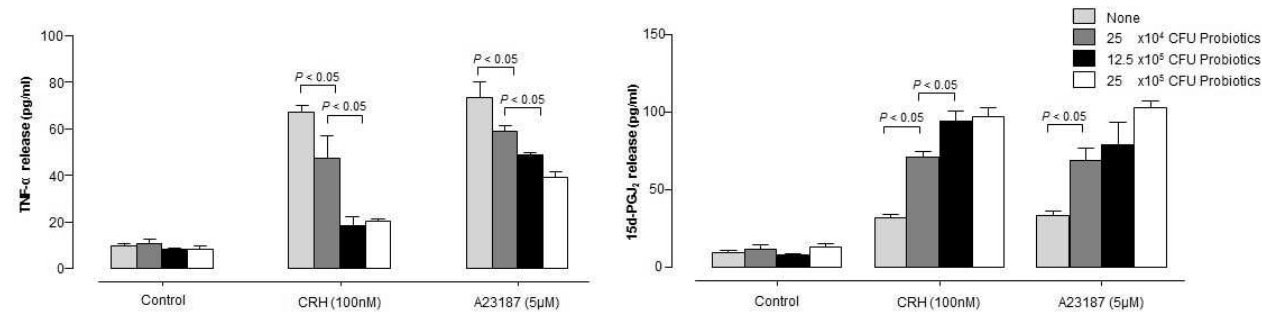

Figure P3-2. Probiotics modulate CRF-induced mediator release from mast cells

A) Bar graph showing that $1 \mathrm{hr}$ pretreatment with probiotics did not induce spontaneous degranulation and decreased both CRF- and A23187-induced release of beta hexosaminidase in a dose dependent fashion. (B) Bar graph showing that $1 \mathrm{hr}$ pretreatment with probiotics reduced both CRF- and A23187-induced release of TNF $\alpha$ dependent of the used probiotic dose. (C) Bar graph showing that $1 \mathrm{hr}$ pretreatment with probiotics resulted in increased CRF- and A23187-induced release of 15d-PGJ2 Data are mean \pm SEM; $n=6$ preparations from 2 experiments. Comparisons were performed using ANOVA followed by Tukey's HSD.

When co-culturing RBL-2H3 mast cells in the bottom of a Transwell chamber with a confluent monolayer of T84 cells on the filter, addition of CRF decreased the transepithelial resistance and increased the passage of fluorescent microspheres. In experiments without mast cells CRF did not have any effect. To test the effect of probiotics in this experimental system probiotics were added to the apical side of the T84 cells one hour prior to CRFstimulation. Probiotic pretreatment caused decreased release of $\beta$-hexosaminidase and TNF $\alpha$ as wells as increased levels of $15 d-P G J_{2}$. Furthermore, the positive effect was also seen as an increased TER and decreased microsphere permeability (figure P3-3). Similar results were observed in experiments where pretreatment with a filter-sterilized probiotic supernatant was used instead of the probiotic mixture. The positive effect on the epithelium could be inhibited by pretreatment with a selective PPAR- $\nu$ blocker.
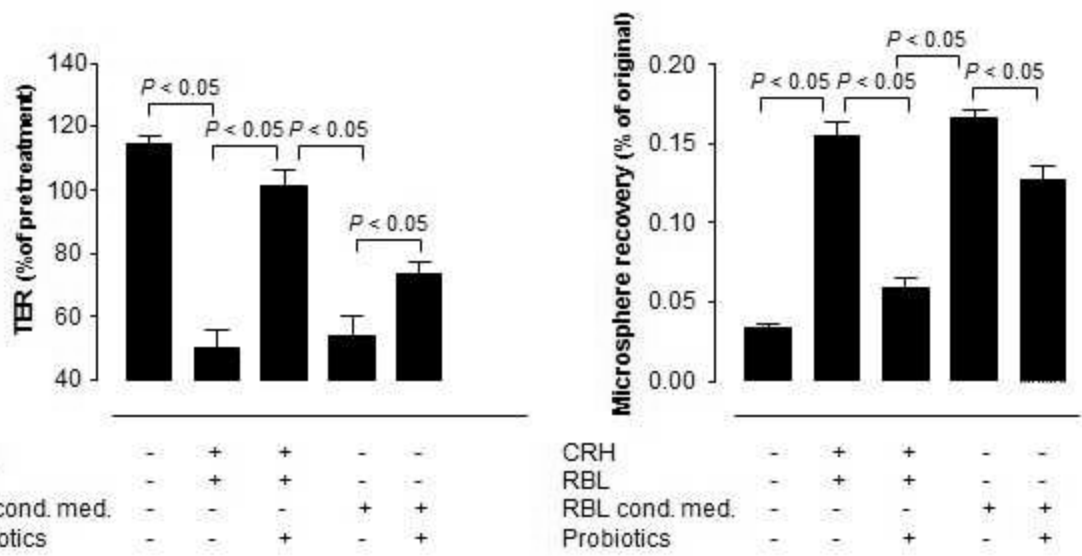

Figure P3-3. Mast cells contribute to probiotic-induced barrier protective effects

Filter-grown T84 monolayers were pretreated for $1 \mathrm{~h}$ with probiotics and either exposed to conditioned medium of CRF activated RBL cells or co-cultured with RBL cells, which were subsequently activated with 100nM CRF. Bar graphs show that pretreatment with probiotics attenuates the deleterious effects in stress-induced epithelial barrier dysfunction as determined by $(A)$ an amelioration of the mast cell-induced drop in transepithelial resistance (TER) and (B) increase in microsphere flux after activation of mast cells. Data are mean \pm SEM; $n=6$ preparations from 2 experiments. Comparisons were performed using ANOVA followed by Tukey's HSD. 
To test whether the barrier-protective effects were PPAR- $\gamma$ dependent, PPAR- $\gamma$ transcription factor levels were measured in confluent plastic grown T84 cells stimulated with conditioned media from CRF-activated mast cells cultured with or without probiotics or probiotic supernatant. The results showed a significant increase in the PPAR- $\psi$ transcription factor concentration after stimulation with conditioned media from CRF-activated mast cells pretreated with probiotics. However, a smaller increase was also seen after simulation with probiotics and conditioned media from CHR activated mast cell but not from probiotic supernatant.

In conclusion, the in vitro data confirms our previous findings (paper II) and gives more information on the mechanisms by which mast cells may be involved in the protective effects of probiotics. The mast cell function was modulated by probiotics and their soluble factors to release less TNF $\alpha$, and more $15 d-P G J_{2}$. This resulted in PPAR- $\gamma$ activation in epithelial cells and maintenance of epithelial barrier function despite CRF-induced mast cell activation. Modulation of mast cell function by probiotics could have important implications for the treatment of stress-induced gastrointestinal disorders.

\section{Paper IV: Faecalibacterium prausnitzii supernatant improves intestinal barrier function in mice with DSS colitis}

To study if probiotic bacteria could ameliorate inflammatory conditions, we used a mouse model with chemically induced colitis. Instead of applying the probiotic mixture used in the two previous manuscripts, we chose to work with a commensal bacterium, Faecalibacterium prausnitzii (FP), which has been proven to be underrepresented in the microflora of Crohn's disease patients ${ }^{235}$.

Mice were divided in to two groups and one of them received 3\% DSS in their drinking water during five days to induce acute colitis. From the third day of experiment and the following seven days some mice received a daily gavage with supernatant from Faecalibacterium prausnitzii and controls only culture broth. The mice were weighed daily, and on the last day of experiment ileum and colon tissue were taken for permeability studies in Ussing chambers. Tissue was also saved for Western blot analyses of tight junction proteins.

There was a more rapid recovery after DSS-induced colitis in mice receiving FP, but the terminal weights were not significantly increased compared to those which received only broth. Significant differences could, however, be seen when comparing colon lengths as a proxy for inflammation. The Ussing chamber permeability experiments showed a significant increase in ${ }^{51}$ CrEDTA passage in ileum after DSS treatment. This effect was significantly smaller in mice, that had received FP supernatant (Figure P4-1). In colon tissue no significant differences could be observed. Neither were there any differences in either ileal or colonic transmucosal passage of $E$. coli $\mathrm{K} 12$. 

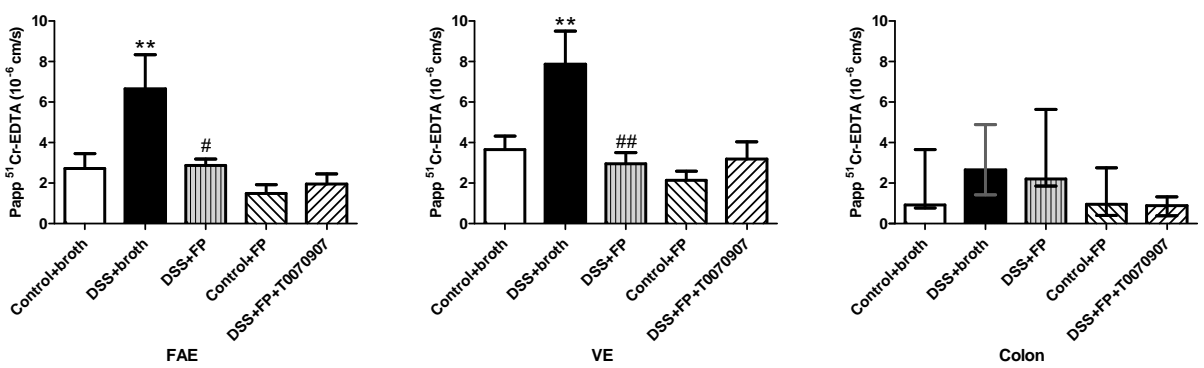

Figure P4-1. Passage of ${ }^{51} \mathrm{Cr}$-EDTA in mouse intestine

Passage of ${ }^{51} \mathrm{Cr}$-EDTA in mouse ileal FAE, VE, and colon epithelium, Comparisons were done with ANOVA and Bonferroni's test, mean $\pm \mathrm{SEM}(\mathrm{A}, \mathrm{B}, \mathrm{D}, \mathrm{E})$, or Kruskal-Wallis, median \pm interquartile range $(C, F) .{ }^{* *} p<0.01$ compared to control + broth, \#p $<0.05$, \#\#p $<0.01$ compared to DSS + broth. (A) Passage of 51Cr-EDTA in FAE. (B) Passage of 51Cr-EDTA in VE. (C) Passage of 51Cr-EDTA in colon. $n=8-12$ mice/group.

Western blots of the tight junction proteins claudin-1 and -2 demonstrated higher expressions of both proteins in colon from DSS-colitis mice. Still, a densitometric analysis only revealed a tendency $(\mathrm{P}=0.06)$ to a higher expression of claudin-1 in DSS mice compared to controls. Claudin-2 expression was also numerically higher in the groups that had received DSS compared to the control group, but not to a significant degree $(P=0.1)$ (figure $P 4-2)$.
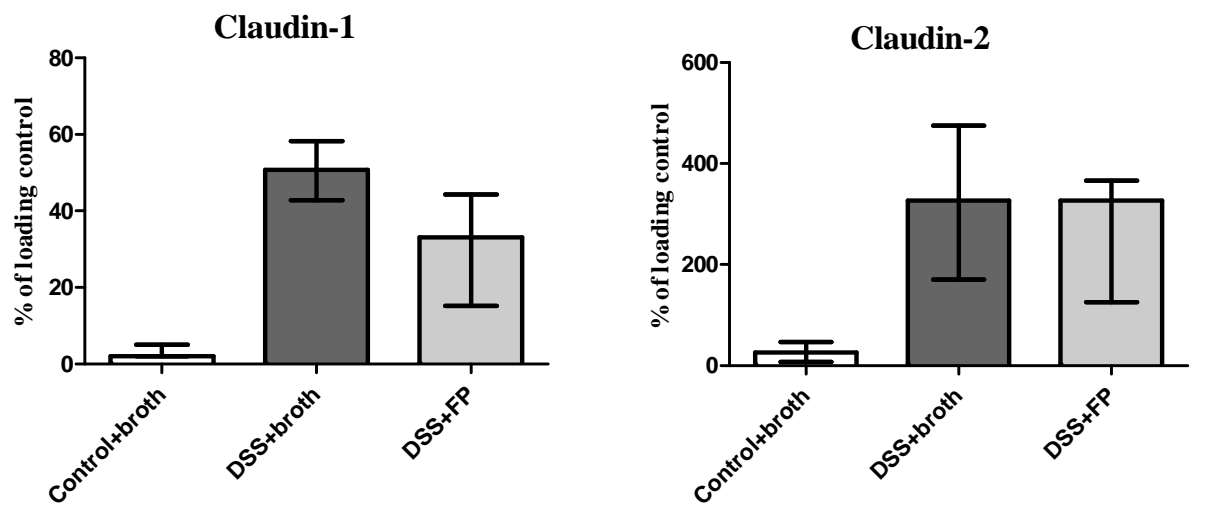

Figure P4-2. Densitometric analyses claudin-1 and claudin-2 from Western blots

Values are presented as median \pm interquartile range and normalized against $b$-actin loading control. $P$ values were calculated using Mann-Whitney test. Band intensities were measured using Image J software. (A) Comparisons of claudin-1 densities showed control + broth vs. DSS + broth $(p=0.06)$, control + broth vs. DSS + FP $(p=0.06)$. (B) Comparisons of claudin-2 densities showed control + broth vs. DSS + broth group $(p=0.1)$, control + broth vs. DSS + FP $(p=0.1) \cdot n=4$ mice/group.

In conclusion, the supernatant from FP enhanced the intestinal barrier function by affecting paracellular permeability and may thereby have ameliorated the DSS-induced colitis in the mice. These findings accentuate the potential efficacy of FP in the treatment of IBD. Further studies are, however, required for a more detailed definition of the processes that underlie these results. 


\section{DISCUSSION}

Mast cell activation has been implicated in many types of disturbances of gut function ${ }^{111}$. Both direct and indirect mechanisms relevant to disease characteristics have been proposed, such as changes in epithelial barrier function and/or activation of adaptive or innate immune responses. Mast cells also function as mediators between the inflammatory cells and the enteric nervous system. Several cell types are affected by the inflammatory environment and upon activation they release mediators which affect the gastrointestinal neuromuscular and secretory functions.

The aim of this thesis was to increase the understanding of mast cell activation, their effects on the regulation of the intestinal barrier function during stress, and how they can be affected by probiotics.

Mast cells have had a central role in this thesis. The results show that mast cells have an active role to play in the effect stress has on intestinal permeability, and the positive effects of probiotics are also partly mediated via mast cells. I will continue to discuss our findings on mast cells in relation to stress and probiotics below. A summarizing illustration showing the different main components of this thesis and their relation to each other are shown in figure

13.

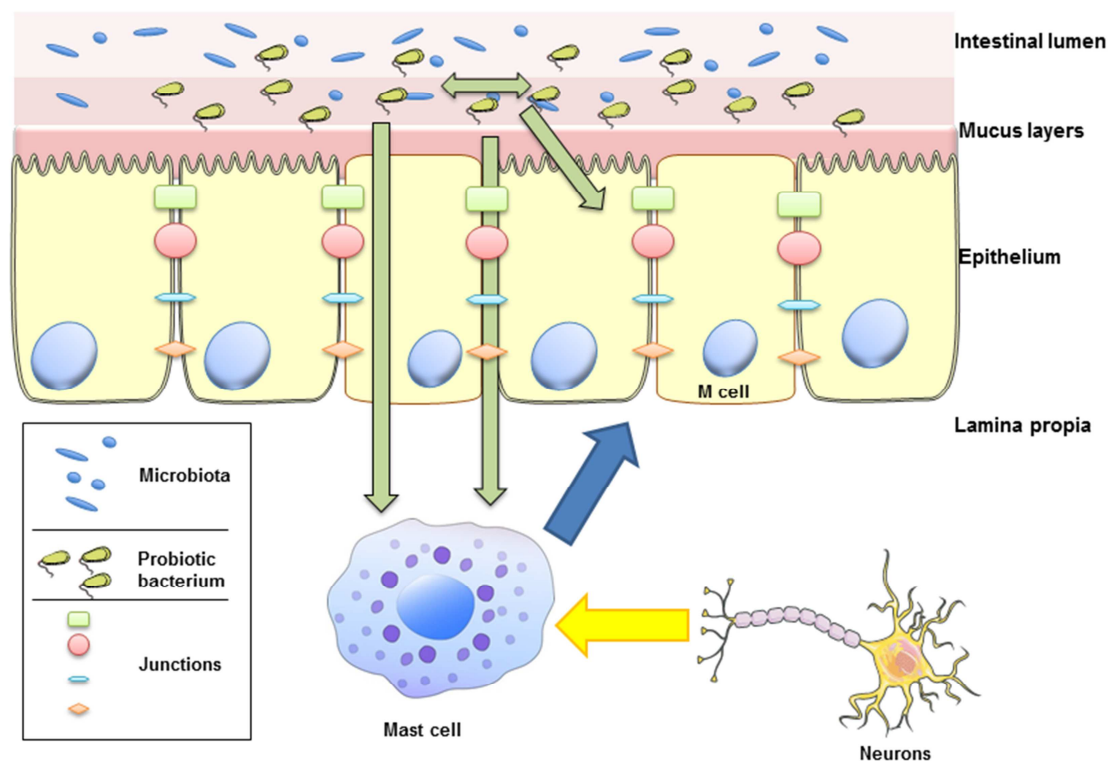

Figure 13. Mast cells, probiotics and stress in intestinal permeability

The figure illustrates the central role of mast cells in the regulation of intestinal function presented in this thesis. The yellow arrow between the neuron and the mast cell represents the effect stress can have on mast cells via VIP and CRF. The green arrows represent the effect probiotics can have on mast cells, epithelia and the luminal microenvironment. An effect mediated through an unidentified soluble factor. The blue arrow represents the effect mast cells can have on epithelial cells, the apical junctional complex and intestinal permeability via mast cell degranulation of $15 \mathrm{~d}-\mathrm{PgJ} \mathrm{J}_{2}$ and TNF $\alpha$. 


\section{Stress}

Stress is a common experience in daily life, and that stress can result in gastrointestinal disorders is well established ${ }^{248}, 249$. Stressful life events worsen the clinical course of CD and prolonged stress raises the number of relapses in UC patients ${ }^{250}$. The studies included in this thesis have employed two similar stress models. In paper 1, acute WAS was used and in paper 2 a model of chronic WAS. In acute WAS, the rats were exposed to 1-hour WAS and in chronic stress they were subjected to 1-hour of WAS for ten consecutive days. WAS in rats is a widely used model of psychological stress and it has been shown, that this chronic form of stress causes a prolonged intestinal barrier dysfunction ${ }^{45,218}$. In the ex vivo experiments with Ussing chambers and in vitro in cell cultures we used CRF to simulate stress. An increase in mucosal permeability could allow antigens and bacteria to penetrate the intestinal barrier, thereby causing mucosal inflammation. Mucosal barrier integrity is known to be affected by stress under experimental conditions by routes involving mast cells ${ }^{251}$. However, it is more difficult to find good models for direct effects of stress on the intestinal barrier in humans. There are many ethical and practical complications but also methodological problems. In this thesis we simulated stress on human tissue in Ussing chambers ex vivo. However, ongoing experiments in our lab are testing a model, where healthy individuals can be subjected to experimental stress under controlled conditions before acquiring intestinal biopsies.

Reports on the involvement of VIP in stress-induced, mucosal permeability changes are scarce. Even so, in a co-culture model of human submucosal neuronal network and human colonic monolayers, the paracellular permeability was decreased by electrical stimulation of submucosal neurons and reproduced by a VIP peptide ${ }^{252}$. Interestingly, the effects were blocked by VIP-receptor antagonists and the neurotoxin tetrodotoxin. When broadening the view to include effects of VIP in general, the findings are divergent. Several studies have revealed that VIP has anti-inflammatory and barrier-enhancing properties ${ }^{253-255}$, which ameliorate experimental colitis ${ }^{253,255}$ and lower paracellular permeability ${ }^{252,256,257}$. However, other studies have shown that VIP also exerts some pro-inflammatory effects. For example, it may promote development of inflammation-associated Th17 cells in response to antigens ${ }^{258,259}$ and decrease IL-8 production in monocytes activated by inflammatory stimuli $^{260}$. Our novel findings, which might seem controversial, suggest that VIP acts via mast cells and is important in regulation of ileal barrier function during stress. A notable difference is that previous studies were performed on mouse colon or cell cultures. Our experiments also showed differences between stress and VIP-effects depending on the anatomical region, i.e. colon vs. ileum. The effect of VIP might thus be dependent on species, intestinal localization, underlying pathological conditions and barrier characteristics. 
In our experiments, VIP had no effect on the paracellular permeability in humans. However, the transcellular passage was significantly increased by VIP, which could be inhibited by VIPreceptor blockers. These findings point to different mechanisms in the regulation of paracellular and transcellular permeability by VIP, and further illustrate the diverse actions of the peptide.

The interaction between mast cells and VIP in barrier function has not previously been reported. In paper 1 , the increased permeability caused by acute stress and VIP, respectively, was totally abolished by mast cell stabilization or a VIP-receptor blocker, indicating that cross-talk between VIP neurons and mast cells is highly important in lleal FAE and VE. An interaction between VIP, mast cells and the epithelium was also confirmed by the co-culture model, showing increased bacterial passage by VIP-stimulated mast cell supernatant, but no effects by VIP alone. Furthermore, the close interaction of VIP and mast cells was also confirmed by IHC showing both VIP-receptor 1 and 2 expressions on intestinal mast cells for both rat and human FAE tissue. Previous publications have identified VIP-receptors on porcine mast cells ${ }^{261}$ and on the human mast cell line HMC-1 ${ }^{262}$. One article has also shown activation by VIP on human skin mast cells, indicating the presence of VIP-receptors on skin mast cells ${ }^{263}$. The novel findings on the effects of VIP on intestinal permeability add to the previous knowledge on how intestinal permeability can be affected by CRF, acetylcholine and substance $\mathrm{P}^{264}$.

\section{Probiotics}

The composition of the intestinal microbial flora has been suggested to play a pivotal role in the pathogenesis of $\mathrm{IBD}^{235,265}$. A decrease in the diversity of microbiota in IBD patients has also previously been documented ${ }^{266,267}$. Consequently there is increasing interest in the therapeutic potential of microflora modifications. Probiotics are live microorganisms, which when administered in adequate amounts, might confer a health benefit on the host ${ }^{268}$. Endogenous probiotic bacteria of the gut, such as Bifidobacterium and Lactobacillus, seem to play a vital role in maintaining the intestinal mucosal barrier ${ }^{201,269}$. Probiotic bacteria have also been shown to modulate intestinal epithelial barrier function and cytokine secretion through effects on epithelial cells and via modulation of the NF-KB and PPAR pathways ${ }^{248,270}$. Furthermore, certain commensal microbes have been suggested to inhibit mast cell degranulation $^{271}$.

Probiotics can be composed of mono-strain, multi-strain or multi-species bacteria depending on the desired purpose, function and effect. In this thesis, we have used a multi-species probiotic mixture (paper $2 \& 3$ ) and the supernatant from a single strain (paper 4). The probiotic mixture Ecologic ${ }^{\circledR} 825$ was developed to extend remission time in IBD patients. The bacteria were chosen on three criteria: 1 . compete with pathogens being associated with IBD (C. difficile, E. coli); 2. Improve the barrier function and 3. Induce the production of antiinflammatory cytokines. A recent publication from our group using this specific mixture of probiotics has shown restored mucosal barrier properties in patients with chronic 
pouchitis $^{272}$. One drawback of working with a mixture of probiotics is that it is harder and time consuming to study the specific effects of each strain. An example is part of paper 3 , where we tested CRF-induced mast cell secretion on RBL-2H3 after pretreatment with each of the probiotic bacteria included in Ecologic ${ }^{\circledR} 825$. The results showed decreased secretion in five of the nine strains included. In paper 4 we therefore decided to take a different approach. Not only did we choose to work with one bacterium, Faecalibacterium prausnitzii, but since it is strictly anaerobic, we also decided to only use supernatant. Faecalibacterium prausnitzii was chosen because Sokol et. al. ${ }^{235}$ found an underrepresentation of this strain in the fecal microbiota in CD patients compared to healthy subjects. In the same publication, they also showed that FP had anti-inflammatory properties and that the supernatant from FP had almost the same positive effect as the bacteria. The appealing idea here was that some soluble factor in the supernatant confers the probiotic effect. Moreover, treatment of patients with a soluble factor would be easier and probably safer than an introduction of a plethora of bacteria in an inflamed intestine. Interestingly, we found that supernatant of Faecalibacterium prausnitzii enhanced intestinal barrier function by affecting paracellular permeability.

Although probiotic effects are extremely interesting to study and currently a hot topic, a warning should be issued when taking the steps from animal experiments to human trials. As an example, when Besselink et al. ${ }^{273}$ gave probiotic profylaxis to patients with predicted severe acute pancreatitis it resulted in more than a two-fold increase in mortality compared to placebo.

Previous studies have shown that the production of mast cell mediators can be modulated by other factors found at inflammatory sites, such as IFN- $\gamma^{274}, \mathrm{PGE}_{2}{ }^{275}$ and IL-10 ${ }^{276}$. In our experiments from paper 2 and 3, probiotic treatment increased mast cell release of 15deoxy- $\triangle$ prostaglandin $\mathrm{J}_{2}\left(15 \mathrm{~d}-\mathrm{PGJ} \mathrm{J}_{2}\right) \cdot 15 \mathrm{~d}-\mathrm{PGJ}_{2}$ is derived from $\mathrm{PGD}_{2}$ and mainly released by mast cells ${ }^{277}$. It is also a high-affinity ligand to PPAR- $\nu^{278}$. Activation of PPAR- $\gamma$ by endogenous agonists, such as $15 \mathrm{~d}-\mathrm{PGJ}_{2}$, or synthetic agonists can be considered as a pathway to halt the inflammatory response. PPAR- $\psi$, exerts anti-inflammatory effects by interfering with the activity of inflammatory transcription factors, such as Activator Protein-1 (AP-1), Signal Transducers and Activators of Transcription (STAT), and nuclear factor KB (NF-KB) ${ }^{279}$.

In paper 2 and 3 we provide novel in vivo and in vitro evidence, that stress-induced elevation in mucosal $15 d-P G J_{2}$ is mast cell dependent and that oral feeding of rats with probiotics further enhances the levels of $15 \mathrm{~d}-\mathrm{PGJ}_{2}$ after exposure to stress. The stress-induced increase in $15 \mathrm{~d}-\mathrm{PGJ}_{2}$ seemed to run parallel with the activation of PPAR- $\gamma$. However, the fact that PPAR- $\gamma$ activity was increased after probiotic treatment of sham-stressed and mast celldeficient animals indicates that probiotic-induced PPAR- $\gamma$ activation was not solely dependent on $15 d-P G J_{2}$ secretion from mast cells. This may be explained by a previous work showing production of conjugated linoleic acid by probiotics, which is known to be a PPAR- $\gamma$ lig$a^{280}$. Degradation of PPAR- $\gamma$ occurs also through the ubiquitin-proteasome system ${ }^{281}$ and probiotics have previously been shown to reduce cellular proteasome activity ${ }^{202,282}$. It is 
therefore possible that probiotics decrease the degradation of PPAR- $\gamma$ and thereby prolongs its activity. In our experiments, we could also see that treatment with the PPAR- $\gamma$ antagonist blocked the positive effect that probiotics exerted on intestinal permeability. Our data thus suggest that mast cells may contribute to the protective effects of probiotics in stressinduced mucosal dysfunction.

\section{Concluding remarks}

The research presented in this thesis contributes to the understanding of the role of mast cells and probiotics during stress.

We present novel data from human, rat and cell culture experiments showing how the neuropeptide VIP acts via mast cells to increase intestinal permeability. Furthermore, we describe how probiotics modulate mast cell- mediator release to a more barrier protective profile, resulting in amelioration of stress-induced epithelial barrier dysfunction being mediated by a PPAR- $\gamma$ dependent pathway. Finally, we show that supernatant from Faecalibacterium prausnitzii enhances the intestinal barrier function by affecting the paracellular permeability.

The findings in this thesis strengthen the theory that mast cells have an important immuneregulatory role on intestinal barrier function and are important players in the brain-gut axis. We also show that probiotics live up to their definition in that they "can confer a health benefit on the host" during modeling of stress and colitis.

Our results could be of importance for understanding the pathogenesis of stress-related intestinal disorders and give clues to new therapeutic approaches targeting mast cells or their receptors. In particular, further research into the interaction between mast cells with CRF and VIP seems promising. The results also show a positive effect of probiotics on intestinal permeability during stress and intestinal inflammation, which strengthens the potential use of probiotics in clinical practice. Important questions to continue to study are if combinations of several strains of probiotic bacteria are better than single-strain preparations, and if we should try to isolate soluble factors produced by probiotic strains. 


\section{CONCLUSIONS}

- Stress effects on ileal permeability can be mimicked in vitro by VIP. These effects are abolished by blocking VIP-receptors and by mast cell stabilizers.

- Human mucosal mast cells express receptors for VIP, and VIP-containing cells and neurons are found in close proximity to mast cells.

- Mast cells, acting via a PPAR- $\gamma$ dependent pathway, contribute to the beneficial effects of probiotics on chronic stress-induced mucosal dysfunction in rats.

- Probiotics modulate mast cell-mediator release to a more barrier-protective profile, resulting in amelioration of stress-induced epithelial barrier dysfunction, mediated by a PPAR- $\gamma$ dependent pathway.

- The supernatant of Faecalibacterium prausnitzii enhances the intestinal barrier function by affecting the paracellular permeability, and may thereby attenuate the severity of DSS-induced colitis in mice. 


\section{ACKNOWLEDGEMENTS}

The work of this thesis has been a collaborative effort and would not have been possible without the contribution, help and support from several persons. I especially wish to acknowledge:

My main supervisor Johan Dabrosin Söderholm, thank you for giving me the opportunity to work with you. It has truly been an educational scientific journey with many ups and downs. It has always felt reassuring to be under your supervision.

My co-supervisor Åsa Keita, thank you for all the support you have shown throughout my entire PhD time. It has always been a pleasure working with you and the support you have given me during the writing of this thesis has been invaluable. It has been great getting to know your husband Alpha and to play with your kids Mathilda, Alexander and Linnea.

My co-supervisor Karl-Eric Magnusson, thank you for your support, knowledge and experience. I think our mutual fascination for microscopy made us connect right from the start. It has always felt comforting to go to you for guidance and your ability to sense when I needed a little encouragement is always perfectly timed.

My Canadian/Irish supervisor Derek McKay, thank you for taking good care of us in you lab in Calgary. It was a pleasure to see how you run your lab, great that we have the same kind of humor and share the same taste in fermented beverages. The way you approach and solve scientific problems is inspiring and is just one of the many reasons why I think you make a good scientific role model. It has been great getting to know you, your lovely wife Catherine and charming daughter Fiona-Mae.

Lab technician Ylva Braaf, for teaching me everything about running Ussing chamber experiments and the good times we had in the lab.

Arthur Wang and Van Phan thank you for all the help and guidance at the lab in Calgary.

My thanks to former/current PhD colleagues and co-authors Conny Wallon, Mats Persborn, Sa'ad Salim, Ida Schultz, Femke Lutgendorff, Olena Yakymenko, Linda Gerdin and Elin Boström Holm for all the time we spent in and outside of the lab.

Postdocs Maria Cigéhn, Isabelle Olivier and Ana Maria Gonzales Castro, thank you for the knowledge you brought to the lab and the enlightening discussions we have had.

All the personnel at the surgery department and endoscopy unit thank you for helping me with my research. I especially want to thank Malin Olsson, Kerstin Fallkvist, Pär Myrelid, Pelle Druvefors and Anders Kald for your assistance in obtaining research samples. 
My students Emily Postma and Fathima Håkansson, for the hard work you put in to your projects and for being easy to supervise.

The administrators Eva Danielsson, Britt-Marie Johansson and Viveca Axén: thank you for making my academic life so much easier by helping out with forms, copies and printing.

Maria Vicario it has been great getting to know you. Thank you for valuable scientific advice and your wonderful sense of humor.

My research school GIMIICum, thank you for giving me a shot and the possibility to network with other PhD students within this research field.

The staff at Medical microbiology, Thank you all for creating a great work atmosphere. Your willingness to help out and the nice discussions during our coffee breaks have made the lab work much easier.

The staff at KEF, particularly Kerstin Hagersten, Anne-Marie Fornander, Florence Sjögren and Pia Karlsson, has been very supportive and friendly. Special thanks to Håkan Wiktander for fixing almost everything and letting me borrow your tools.

The plastic surgery lab, Gunnar Kratz, Hans Vintertun, Kristina Briheim, Anita Lönn, for socially adopting me and letting me join your lab parties.

The staff at the animal house, Jan Szymanowski, Dan Linghammar, Anne Halldén Waldemarson and Anna Fyrberg, with everything from designing the animal experiments to writing the ethical applications and performing the experiments.

To teachers, students and Susanne Andersson at the Master of Science program in Medical Biology at Linköping University, for creating a great studying environment and creating a good foundation for future scientific studies.

My dear friends: Johan Junker - for being one of my best friends and looking out for me since my first day on medbi.

Jonas Ungerbäck - for your positive, negative thinking and awesome cooking skills.

Jerker Linné \& Anders Millerhovf - my good ol’ medbi pals. I remember and sometimes miss the great times we had during our MSc program.

Patiyan Andersson \& Lauren - for being great friends. I really miss you guys over here and the great times we had down under.

Joakim Henricson - for being a great friend and always being there ready to hangout or to watch a movie.

Mikael Pihl for all the countless hours we spent gaming and for being a vital part of the dinner crew. 
Jonathan Rakar \& Sofie Sundberg - For providing an awesome gaming experience and for cozy dinners, respectively.

Susanna Lönnqvist - You are my favorite person to be socially awkward with. SYLT!

Sebastian Schultz, Torsten Feichtinger, Johannes Stratmann - Thank you for being great friends. You guys put the germ in Germany

Joanne Hackett \& Ryan MacDonald - For being great friends, keeping it real and always bringing it when it comes to partying.

Faisal Omar for all the great times we had and for being an awesome buddy. I look forward to visiting you in Toronto.

Alexander Persson, Carl-Oscar Jonson - for being great friends and good examples as "older" medbi-students.

Johan Olausson \& Patrik Olausson - for always leading a good example when it comes to partying.

Cici Möller \& Linnea Sandin - For being the girlfriends of my friends girlfriends. Your presence always appreciated to even out the gender quota and adding a feminine touch.

Anna Rydén, thank you for being one of my dearest friends and for all the good times we shared.

Samuel \& Elin Smith, Anders \& Sofia Alexandersson, Kim \& Louise Karlsson, Pontus Svensson, Christian Runesson- Jag uppskattar verkligen att vi håller kontakten trots att avstånd minskar tillfällena. Ni är några av mina äldsta bekantskaper, bästa vänner och jag hoppas verkligen att vi håller fortsatt bra kontakt.

Till min farmor, farfar, mormor, morfar, faster, mostrar och kusiner, tack för all omtanke och uppmuntran. Det är alltid roligt när vi träffas och jag hoppas att ni har överseende med att jag inte hälsat på så mycket som jag borde de senaste åren.

Till min mamma, pappa och lillebror, Tack för all uppmuntran och kärlek. Det betyder enormt mycket och känns oerhört skönt att få uppleva sådant ovillkorligt stöd. Med visdomsord som "En Carlsson ger sig aldrig" kan det väl inte gå snett... 
Artis, D. Epithelial-cell recognition of commensal bacteria and maintenance of immune homeostasis in the gut. Nature reviews. Immunology 8, 411-420 (2008)

2. Salim, S.Y. \& Soderholm, J.D. Importance of disrupted intestinal barrier in inflammatory bowel diseases. Inflammatory bowel diseases.

3. Heyman, M. Gut barrier dysfunction in food allergy. European journal of gastroenterology \& hepatology 17 1279-1285 (2005).

4. Keita, A.V. \& Soderholm, J.D. The intestinal barrier and its regulation by neuroimmune factors. Neurogastroenterol Motil 22, 718-733.

5. Ermund, A., Schutte, A., Johansson, M.E., Gustafsson, J.K. \& Hansson, G.C. Studies of mucus in mouse stomach, small intestine, and colon. I. Gastrointestinal mucus layers have different properties depending on location as well as over the Peyer's patches. American journal of physiology. Gastrointestinal and liver physiology 305, G341-347 (2013)

6. Gebert, A., Rothkotter, H.J. \& Pabst, R. M cells in Peyer's patches of the intestine. International review of cytology 167, 91-159 (1996).

7. Gebert, A. M cells in the rabbit palatine tonsil: the distribution, spatial arrangement and membrane subdomains as defined by confocal lectin histochemistry. Anatomy and embryology 195, 353-358 (1997).

8. Gebert, A. The role of $\mathrm{M}$ cells in the protection of mucosal membranes. Histochemistry and cell biology 108, 455-470 (1997).

9. Neutra, M.R., Mantis, N.J. \& Kraehenbuhl, J.P. Collaboration of epithelial cells with organized mucosal lymphoid tissues. Nature immunology 2, 1004-1009 (2001).

10. Gebert, A., Steinmetz, I., Fassbender, S. \& Wendlandt, K.H. Antigen transport into Peyer's patches: increased uptake by constant numbers of $\mathrm{M}$ cells. The American journal of pathology 164, 65-72 (2004).

11. Chen, X., D'Souza, R. \& Hong, S.T. The role of gut microbiota in the gut-brain axis: current challenges and perspectives. Protein \& cell 4, 403-414 (2013).

12. Grenham, S., Clarke, G., Cryan, J.F. \& Dinan, T.G. Brain-gut-microbe communication in health and disease. Frontiers in physiology 2, 94 (2011).

13. van der Heijden, P.J., Stok, W. \& Bianchi, A.T. Contribution of immunoglobulin-secreting cells in the murine small intestine to the total 'background' immunoglobulin production. Immunology 62, 551-555 (1987).

14. Kraehenbuhl, J.P. \& Corbett, M. Immunology. Keeping the gut microflora at bay. Science 303, 1624-1625 (2004).

15. Makala, L.H., Suzuki, N. \& Nagasawa, H. Peyer's patches: organized lymphoid structures for the induction of mucosal immune responses in the induction of mucosal immune responses in the
intestine. Pathobiology : journal of immunopathology, molecular and cellular biology 70, 55-68 (2002).

16. Rescigno, M. et al. Dendritic cells express tight junction proteins and penetrate gut epithelial monolayers to sample bacteria. Nature immunology 2 , 361-367 (2001).

17. Fleeton, M., et al. Involvement of dendritic cell subsets in the induction of oral tolerance and immunity. Annals of the New York Academy of Sciences 1029, 60-65 (2004).

18. Nagler-Anderson, C. Man the barrier! Strategic defences in the intestinal mucosa. Nature reviews. Immunology 1, 59-67 (2001).

19. Scaldaferri, F., et al. Gut Microbial Flora, Prebiotics, and Probiotics in IBD: Their Current Usage and Utility. BioMed research international 2013, 435268 (2013).

20. O'Hara, A.M. \& Shanahan, F. The gut flora as forgotten organ. EMBO reports 7, 688-693 (2006).

21. Karlsson, F., Tremaroli, V., Nielsen, J. \& Backhed, F. Assessing the human gut microbiota in metabolic diseases. Diabetes 62, 3341-3349 (2013).
Xu, J. \& Gordon, J.I. Honor thy symbionts. Proceeding of the National Academy of Sciences of the United States of America 100, 10452-10459 (2003).

23. Sommer, F. \& Backhed, F. The gut microbiota--masters of host development and physiology. Nature reviews. Microbiology 11, 227-238 (2013).

24. Schmidt, C. \& Stallmach, A. Etiology and pathogenesis of inflammatory bowel disease. Minerva gastroenterologica e dietologica 51, 127-145 (2005).

25. Eckburg, P.B., Lepp, P.W. \& Relman, D.A. Archaea and their potential role in human disease. Infection and immunity 71, 591-596 (2003)

26. Breitbart, $M$. et al. Metagenomic analyses of an uncultured viral community from human feces. Journal of bacteriology 185, 6220-6223 (2003).

27. Smith, K., McCoy, K.D. \& Macpherson, A.J. Use of axenic animals in studying the adaptation of mammals to their commensal intestinal microbiota. Seminars in immunology 19, 59-69 (2007).

28. Stappenbeck, T.S., Hooper, L.V. \& Gordon, J.I. Developmental regulation of intestinal angiogenesis by indigenous microbes via Paneth cells. Proceedings of the National Academy of Sciences of the United States of America 99, 15451-15455 (2002).

29. Kawamoto, S., et al. The inhibitory receptor PD-1 regulates IgA selection and bacterial composition in the gut. Science 336, 485-489 (2012).

30. Larsson, E., et al. Analysis of gut microbial regulation of host gene expression along the length of the gut and regulation of gut microbial ecology through MyD88. Gut 61, 1124-1131 (2012)

31. Backhed, F., et al. The gut microbiota as an environmental factor that regulates fat storage. Proceedings of the National Academy of Sciences of the United States of America 101, 15718-15723 (2004).

32. Sjogren, K., et al. The gut microbiota regulates bone mass in mice. Journal of bone and mineral research the official journal of the American Society for Bone and Mineral Research 27, 1357-1367 (2012).

33. Keita, A.V. \& Soderholm, J.D. The intestinal barrier and its regulation by neuroimmune factors. Neurogastroenterology and motility : the official journal of the European Gastrointestinal Motility Society 22, 718-733 (2010)

34. Scaldaferri, F., Pizzoferrato, M., Gerardi, V., Lopetuso L. \& Gasbarrini, A. The gut barrier: new acquisitions and therapeutic approaches. Journal of clinical gastroenterology 46 Suppl, S12-17 (2012).

35. McEwen, B.S. From molecules to mind. Stress individual differences, and the social environment. Annals of the New York Academy of Sciences 935, 4249 (2001).

36. Selye, H. Implications of stress concept. New York state journal of medicine 75, 2139-2145 (1975).

37. Lupien, S.J., McEwen, B.S., Gunnar, M.R. \& Heim, C Effects of stress throughout the lifespan on the brain, behaviour and cognition. Nature reviews. Neuroscience 10, 434-445 (2009).

38. Eiland, L. \& Romeo, R.D. Stress and the developing adolescent brain. Neuroscience 249, 162-171 (2013).

39. Herman, J.P., et al. Central mechanisms of stress integration: hierarchical circuitry controlling hypothalamo-pituitary-adrenocortical responsiveness. Frontiers in neuroendocrinology 24, 151-180 (2003).

40. Steptoe, A. \& Kivimaki, M. Stress and cardiovascula disease. Nature reviews. Cardiology 9, 360-370 (2012).

41. Theoharides, T.C., et al. Contribution of stress to asthma worsening through mast cell activation. Annals of allergy, asthma \& immunology : official publication of the American College of Allergy, Asthma, \& Immunology 109, 14-19 (2012).

42. Saunders, P.R., et al. Noradrenergic and cholinergic neural pathways mediate stress-induced reactivation of colitis in the rat. Autonomic neuroscience : basic \& clinical 124, 56-68 (2006).

43. Barreau, F., Salvador-Cartier, C., Houdeau, E., Bueno, L. \& Fioramonti, J. Long-term alterations of colonic 
45. Velin, A.K., Ericson, A.C., Braaf, Y., Wallon, C. \& Soderholm, J.D. Increased antigen and bacterial uptake in follicle associated epithelium induced by chronic psychological stress in rats. Gut 53, 494-500 (2004)

46. Mawdsley, J.E. \& Rampton, D.S. Psychological stress in IBD: new insights into pathogenic and therapeutic implications. Gut 54, 1481-1491 (2005).

47. Ghoshal, U.C., Park, H. \& Gwee, K.A. Bugs and irritable bowel syndrome: The good, the bad and the ugly. Journal of gastroenterology and hepatology 25 244-251.

48. Manaka, H., Manaka, Y. Kostolanska, F, Fox, J.E. \& Daniel, E.E. Release of VIP and substance $P$ from isolated perfused canine ileum. The American journal of physiology 257, G182-190 (1989)

49. Quin, J.A., et al. PYY inhibition of VIP-stimulated ion transport in the rabbit distal ileum. The Journal of surgical research 58, 111-115 (1995).

50. Waldman, D.B., Gardner, J.D., Zfass, A.M. \& Makhlouf, G.M. Effects of vasoactive intestinal peptide, secretin, and related peptides on rat colonic transport and adenylate cyclase activity. Gastroenterology 73, 518523 (1977).

51. Dickson, L. \& Finlayson, K. VPAC and PAC receptors: From ligands to function. Pharmacology \& therapeutics 121, 294-316 (2009).

52. Lelievre, V., et al. Gastrointestinal dysfunction in mice with a targeted mutation in the gene encoding vasoactive intestinal polypeptide: a model for the study of intestinal ileus and Hirschsprung's disease. Peptides 28, 1688-1699 (2007).

53. Neunlist, M., et al. Human ENS regulates the intestinal epithelial barrier permeability and a tight junctionassociated protein ZO-1 via VIPergic pathways. American journal of physiology. Gastrointestinal and liver physiology 285, G1028-1036 (2003).

54. Moriez, R., et al. Neuroplasticity and neuroprotection in enteric neurons: role of epithelial cells. Biochemical and biophysical research communications 382, 577 582 (2009).

55. Delgado, M. \& Ganea, D. Inhibition of endotoxin induced macrophage chemokine production by vasoactive intestinal peptide and pituitary adenylate cyclase-activating polypeptide in vitro and in vivo. $J$ Immunol 167, 966-975 (2001)

56. Abad, C., et al. Therapeutic effects of vasoactive intestinal peptide in the trinitrobenzene sulfonic acid mice model of Crohn's disease. Gastroenterology 124 961-971 (2003).

57. Gomariz, R.P., et al. Time-course expression of Tolllike receptors 2 and 4 in inflammatory bowel disease and homeostatic effect of VIP. Journal of leukocyte biology 78, 491-502 (2005).

58. Cao, S.G., Wu, W.C., Han, Z. \& Wang, M.Y. Effects of psychological stress on small intestinal motility and expression of cholecystokinin and vasoactive intestinal polypeptide in plasma and small intestine in mice. World J Gastroenterol 11, 737-740 (2005).

59. Ikenouchi, J., Furuse, M., Furuse, K., Sasaki, H. \& Tsukita, S. Tricellulin constitutes a novel barrier at tricellular contacts of epithelial cells. The Journal of cell biology 171, 939-945 (2005).

60. Assimakopoulos, S.F., Papageorgiou, I. \& Charonis, A Enterocytes' tight junctions: From molecules to diseases. World journal of gastrointestinal pathophysiology 2, 123-137 (2011).

61. Van Itallie, C.M. \& Anderson, J.M. Claudins and epithelial paracellular transport. Annual review of physiology 68, 403-429 (2006).

62. Gonzalez-Mariscal, L., Betanzos, A., Nava, P. \& Jaramillo, B.E. Tight junction proteins. Progress in biophysics and molecular biology 81, 1-44 (2003).

63. Fanning, A.S., Mitic, L.L. \& Anderson, J.M Transmembrane proteins in the tight junction barrier. Journal of the American Society of Nephrology : JASN 10, 1337-1345 (1999).

64. Tsukamoto, T. \& Nigam, S.K. Role of tyrosine phosphorylation in the reassembly of occludin and

other tight junction proteins. The American journal of physiology 276, F737-750 (1999).

65. Dye, J.F., Leach, L., Clark, P. \& Firth, J.A. Cyclic AMP and acidic fibroblast growth factor have opposing effects on tight and adherens junctions in microvascular endothelial cells in vitro. Microvascular research 62, 94-113 (2001).

66. Oshima, T., et al. Interferon-gamma and interleukin-10 reciprocally regulate endothelial junction integrity and barrier function. Microvascular research 61, 130-143 (2001).

67. McClane, B.A. The complex interactions between Clostridium perfringens enterotoxin and epithelial tight junctions. Toxicon : official journal of the International Society on Toxinology 39, 1781-1791 (2001).

68. Burns, A.R., et al. Analysis of tight junctions during neutrophil transendothelial migration. Journal of cell science 113 ( Pt 1), 45-57 (2000).

69. Lechner, $\mathrm{J}$, et al Effects of interferon alpha-2b on barrier function and junctional complexes of renal proximal tubular LLC-PK1 cells. Kidney international 55, 2178-2191 (1999).

70. Massoumi, R. \& Sjolander, A. The inflammatory mediator leukotriene D4 triggers a rapid reorganisation of the actin cytoskeleton in human intestinal epithelial cells. European journal of cell biology 76, 185-191 (1998).

71. Camilleri, M., Madsen, K., Spiller, R., Greenwood-Van Meerveld, B. \& Verne, G.N. Intestinal barrier function in health and gastrointestinal disease. Neurogastroenterology and motility : the official journal of the European Gastrointestinal Motility Society 24, 503-512 (2012).

72. Martinez, C., et al. Diarrhoea-predominant irritable bowel syndrome: an organic disorder with structural abnormalities in the jejunal epithelial barrier. Gut (2012).

73. Martinez, C., Gonzalez-Castro, A., Vicario, M. \& Santos, J. Cellular and molecular basis of intestinal barrier dysfunction in the irritable bowel syndrome. Gut and liver 6, 305-315 (2012).

74. Soderholm, J.D., et al. Augmented increase in tight junction permeability by luminal stimuli in the noninflamed ileum of Crohn's disease. Gut 50, 307-313 (2002).

75. Suzuki, T Regulation of intestinal epithelial permeability by tight junctions. Cellular and molecular life sciences : CMLS 70, 631-659 (2013)

76. Bertocchi, C., Vaman Rao, M. \& Zaidel-Bar, R. Regulation of adherens junction dynamics by phosphorylation switches. Journal of signal transduction 2012, 125295 (2012).

77. Thomason, H.A., Scothern, A., McHarg, S. \& Garrod, D.R. Desmosomes: adhesive strength and signalling in health and disease. The Biochemical journal 429, 419433 (2010).

78. Mese, G., Richard, G. \& White, T.W. Gap junctions: basic structure and function. The Journal of investigative dermatology 127, 2516-2524 (2007).

79. Nielsen, M.S., et al. Gap junctions. Comprehensive Nielsen, M.S., et al. Gap junction
Physiology 2, 1981-2035 (2012).

80. Doherty, G.J. \& McMahon, H.T. Mechanisms of endocytosis. Annual review of biochemistry 78, 857902 (2009).

81. Ivanov, A.I., Nusrat, A. \& Parkos, C.A. The epithelium in inflammatory bowel disease: potential role of endocytosis of junctional proteins in barrier disruption. Novartis Foundation symposium 263, 115-124 discussion 124-132, 211-118 (2004).

82. Shen, L. \& Turner, J.R. Actin depolymerization disrupts tight junctions via caveolae-mediated endocytosis. Molecular biology of the cell 16, 3919-3936 (2005).

83. Parr, R.D., et al. The rotavirus enterotoxin NSP4 directly interacts with the caveolar structural protein caveolin-1. Journal of virology 80, 2842-2854 (2006).

84. Chadda, R., et al. Cholesterol-sensitive Cdc42 activation regulates actin polymerization for endocytosis via the GEEC pathway. Traffic 8, 702-717 (2007).

85. Kalia, M., et al. Arf6-independent GPI-anchored protein-enriched early endosomal compartments fuse with sorting endosomes via a Rab5/phosphatidylinositol-3'-kinase-dependent machinery. Molecular biology of the cell 17, 3689-3704 (2006). 

stimulation shifts the mechanism of endocytosis from dynamin-1-dependent rapid endocytosis to clathrinand dynamin-2-mediated slow endocytosis in chromaffin cells. Proceedings of the National Academy of Sciences of the United States of America 99, 63586363 (2002).

87. Kinchen, J.M. \& Ravichandran, K.S. Phagosome maturation: going through the acid test. Nature reviews. Molecular cell biology 9, 781-795 (2008).

88. Bohdanowicz, M. \& Grinstein, S. Role of phospholipids in endocytosis, phagocytosis, and macropinocytosis. Physiological reviews 93, 69-106 (2013).

89. Neal, M.D., et al. Enterocyte TLR4 mediates phagocytosis and translocation of bacteria across the intestinal barrier. J Immunol 176, 3070-3079 (2006).

90. Lu, L. \& Walker, W.A. Pathologic and physiologic interactions of bacteria with the gastrointestina epithelium. The American journal of clinical nutrition 73 1124S-1130S (2001)

91. Conner, S.D. \& Schmid, S.L. Regulated portals of entry into the cell. Nature 422, 37-44 (2003).

92. Schurmann, G., et al. Transepithelial transport processes at the intestinal mucosa in inflammatory bowel disease. International journal of colorectal disease 14, 41-46 (1999)

93. Meier, O., et al. Adenovirus triggers macropinocytosis and endosomal leakage together with its clathrinmediated uptake. The Journal of cell biology 158 1119-1131 (2002).

94. Mostov, K.E., Verges, M. \& Altschuler, Y. Membrane traffic in polarized epithelial cells. Current opinion in cell biology 12, 483-490 (2000).

95. Metz, M., Siebenhaar, F. \& Maurer, M. Mast cell functions in the innate skin immune system. Immunobiology 213, 251-260 (2008).

96. Abraham, S.N. \& St John, A.L. Mast cell-orchestrated immunity to pathogens. Nature reviews. Immunology 10, 440-452 (2010).

97. Ribatti, D. \& Crivellato, E. Mast cells, angiogenesis, and tumour growth. Biochimica et biophysica acta 1822, 2-8 (2012)

98. Galinsky, D.S. \& Nechushtan, H. Mast cells and cancer--no longer just basic science. Critical reviews in oncology/hematology 68, 115-130 (2008).

99. Maltby, S., Khazaie, K. \& McNagny, K.M. Mast cells in tumor growth: angiogenesis, tissue remodelling and immune-modulation. Biochimica et biophysica acta 1796, 19-26 (2009)

100. Ribatti, D. \& Crivellato, E. Mast cells, angiogenesis and cancer. Advances in experimental medicine and biology 716, 270-288 (2011).

101. Marshall, J.S. \& Bienenstock, J. The role of mast cells in inflammatory reactions of the airways, skin and intestine. Current opinion in immunology 6, 853-859 (1994).

102. Bienenstock, J., et al. Comparative aspects of mast cell heterogeneity in different species and sites. International archives of allergy and applied immunology 77, 126-129 (1985).

103. Shanahan, F., et al. Human lung mast cells: distribution and abundance of histochemically distinct subpopulations. International archives of allergy and applied immunology 83, 329-331 (1987).

104. Silver, R., Silverman, A.J., Vitkovic, L. \& Lederhendler, II. Mast cells in the brain: evidence and functiona significance. Trends in neurosciences 19, 25-31 (1996).

105. Fodinger, M., et al. Origin of human mast cells: development from transplanted hematopoietic stem cells after allogeneic bone marrow transplantation. Blood 84, 2954-2959 (1994).

106. Kirshenbaum, A.S., et al. Demonstration that human mast cells arise from a progenitor cell population that is CD34(+), c-kit(+), and expresses aminopeptidase $\mathrm{N}$ (CD13). Blood 94, 2333-2342 (1999).

107. Hallgren, J. \& Gurish, M.F. Pathways of murine mast cell development and trafficking: tracking the roots and routes of the mast cell. Immunological reviews 217,8 18 (2007)

108. Metcalfe, D.D., Baram, D. \& Mekori, Y.A. Mast cells. Physiological reviews 77, 1033-1079 (1997).

109. Miller, H.R. \& Pemberton, A.D. Tissue-specific expression of mast cell granule serine proteinases and their role in inflammation in the lung and gut. Immunology 105, 375-390 (2002).
110. McNeil, H.P. \& Gotis-Graham, I. Human mast cell subsets--distinct functions in inflammation? Inflammation research : official journal of the European Histamine Research Society ... [et al.] 49, 3-7 (2000).

111. Rijnierse, A., Nijkamp, F.P. \& Kraneveld, A.D. Mast cells and nerves tickle in the tummy: implications for inflammatory bowel disease and irritable bowel syndrome. Pharmacology \& therapeutics 116, 207-235 (2007).

112. Bischoff, S.C. Role of mast cells in allergic and nonallergic immune responses: comparison of human and murine data. Nature reviews. Immunology 7, 93-104 (2007).

113. Galli, S.J., et al. Mast cells as "tunable" effector and immunoregulatory cells: recent advances. Annual review of immunology 23, 749-786 (2005).

114. Gilfillan, A.M. \& Tkaczyk, C. Integrated signalling pathways for mast-cell activation. Nature reviews. Immunology 6, 218-230 (2006).

115. Marshall, J.S. Mast-cell responses to pathogens. Nature reviews. Immunology 4, 787-799 (2004).

116. Muller-Eberhard, H.J. Molecular organization and function of the complement system. Annual review of biochemistry 57, 321-347 (1988).

117. Fureder, W., et al. Differential expression of complement receptors on human basophils and mast cells. Evidence for mast cell heterogeneity and CD88/C5aR expression on skin mast cells. J Immunol 155, 3152-3160 (1995)

118. Lennartsson, J., Jelacic, T., Linnekin, D. \& Shivakrupa, R. Normal and oncogenic forms of the recepto tyrosine kinase kit. Stem Cells 23, 16-43 (2005).

119. Jensen, B.M., Akin, C. \& Gilfillan, A.M. Pharmacological targeting of the KIT growth factor receptor: a therapeutic consideration for mast cell disorders. British journal of pharmacology 154, 15721582 (2008).

120. Hundley, T.R., et al. Kit and FcepsilonRI mediate unique and convergent signals for release of inflammatory mediators from human mast cells. Blood 104, 2410-2417 (2004)

121. Gilfillan, A.M. \& Beaven, M.A. Regulation of mast cell responses in health and disease. Critical reviews in immunology 31, 475-529 (2011).

122. Kulka, M., Sheen, C.H., Tancowny, B.P., Grammer, L.C. \& Schleimer, R.P. Neuropeptides activate human mast cell degranulation and chemokine production. Immunology 123, 398-410 (2008).

123. Pundir, P. \& Kulka, M. The role of $\mathrm{G}$ protein-coupled receptors in mast cell activation by antimicrobia peptides: is there a connection? Immunology and cell biology 88, 632-640 (2010)

124. Wallon, C. \& Soderholm, J.D. Corticotropin-releasing hormone and mast cells in the regulation of mucosa barrier function in the human colon. Annals of the New York Academy of Sciences 1165, 206-210 (2009).

125. Wallon, C., et al. Corticotropin-releasing hormone $(\mathrm{CRH})$ regulates macromolecular permeability via mast cells in normal human colonic biopsies in vitro. Gut $\mathbf{5 7}$ 50-58 (2008).

126. Keita, A.V., et al. Vasoactive intestinal polypeptide regulates barrier function via mast cells in human intestinal follicle-associated epithelium and during stress in rats. Neurogastroenterology and motility : the official journal of the European Gastrointestinal Motility Society 25, e406-417 (2013).

127. Soderholm, J.D. Mast cells and mastocytosis. Dig Dis 27 Suppl 1, 129-136 (2009).

128. Yount, N.Y., Bayer, A.S., Xiong, Y.Q. \& Yeaman, M.R Advances in antimicrobial peptide immunobiology. Biopolymers 84, 435-458 (2006).

129. Niyonsaba, F., et al. Antimicrobial peptides human beta-defensins and cathelicidin LL-37 induce the secretion of a pruritogenic cytokine IL-31 by human mast cells. J Immunol 184, 3526-3534 (2010).

130. Yoshioka, M., et al. Human cathelicidin CAP18/LL-37 changes mast cell function toward innate immunity. Biological \& pharmaceutical bulletin 31, 212-216 (2008).

131. Iwaki, S., et al. Btk plays a crucial role in the amplification of Fc epsilonRl-mediated mast cell activation by kit. The Journal of biological chemistry 280, 40261-40270 (2005).

132. McNeil, H.P., Adachi, R. \& Stevens, R.L. Mast cellrestricted tryptases: structure and function in 
inflammation and pathogen defense. The Journal of biological chemistry 282, 20785-20789 (2007).

133. Stevens, R.L. \& Adachi, R. Protease-proteoglycan complexes of mouse and human mast cells and importance of their beta-tryptase-heparin complexes in inflammation and innate immunity. Immunological reviews 217, 155-167 (2007).

134. Jones, B.L. \& Kearns, G.L. Histamine: new thoughts about a familiar mediator. Clinical pharmacology and therapeutics 89, 189-197 (2011).

135. Boyce, J.A. Eicosanoid mediators of mast cells: receptors, regulation of synthesis, and pathobiologic implications. Chemical immunology and allergy 87, 59 79 (2005).

136. Okayama, Y. Mast cell-derived cytokine expression induced via Fc receptors and Toll-like receptors. Chemical immunology and allergy 87, 101-110 (2005).

137. Okayama, Y., Hagaman, D.D. \& Metcalfe, D.D. A comparison of mediators released or generated by IFN-gamma-treated human mast cells following aggregation of FC gamma RI or Fc epsilon RI. J Immunol 166, 4705-4712 (2001).

138. Crivellato, E., Beltrami, C.A., Mallardi, F. \& Ribatti, D. The mast cell: an active participant or an innocent bystander? Histology and histopathology 19, 259-270 (2004)

139. Silver, R.B., et al. Mast cells: a unique source of renin Proceedings of the National Academy of Sciences of the United States of America 101, 13607-13612 (2004).

140. Malaviya, R., Ikeda, T., Ross, E. \& Abraham, S.N. Mast cell modulation of neutrophil influx and bacterial clearance at sites of infection through TNF-alpha. Nature 381, 77-80 (1996)

141. Sutherland, R.E., Olsen, J.S., McKinstry, A., Villalta, S.A. \& Wolters, P.J. Mast cell IL-6 improves survival from Klebsiella pneumonia and sepsis by enhancing neutrophil killing. J Immunol 181, 5598-5605 (2008).

142. Shelburne, C.P., et al. Mast cells augment adaptive immunity by orchestrating dendritic cell trafficking through infected tissues. Cell host \& microbe 6, 331342 (2009).

143. Wershil, B.K., Castagliuolo, I. \& Pothoulakis, C. Direct evidence of mast cell involvement in Clostridium difficile toxin A-induced enteritis in mice. Gastroenterology 114, 956-964 (1998).

144. Malaviya, R. \& Abraham, S.N. Role of mast cell Malaviya, R. \& Abraham, S.N. Role of mast cell
leukotrienes in neutrophil recruitment and bacterial clearance in infectious peritonitis. Journal of leukocyte biology 67, 841-846 (2000).

145. Choi, S.Y., et al. A common lipid links Mfn-mediated mitochondrial fusion and SNARE-regulated exocytosis. Nature cell biology 8, 1255-1262 (2006).

146. Orinska, Z., et al. TLR3-induced activation of mast cells modulates CD8+ T-cell recruitment. Blood 106, 978987 (2005).

147. Urb, M., Pouliot, P., Gravelat, F.N., Olivier, M. \& Sheppard, D.C. Aspergillus fumigatus induces immunoglobulin E-independent mast cell degranulation. The Journal of infectious diseases 200 464-472 (2009).

148. Larsen, F.O., et al. The indoor microfungus Trichoderma viride potentiates histamine release from human bronchoalveolar cells. APMIS : acta pathologica, microbiologica, et immunologica Scandinavica 104, 673-679 (1996).

149. Edelson, B.T., Li, Z., Pappan, L.K. \& Zutter, M.M. Mast cell-mediated inflammatory responses require the alpha 2 beta 1 integrin. Blood 103, 2214-2220 (2004).

150. McCurdy, J.D., Olynych, T.J., Maher, L.H. \& Marshall, J.S. Cutting edge: distinct Toll-like receptor 2 activators selectively induce different classes of mediator production from human mast cells. $J$ Immunol 170 1625-1629 (2003).

151. Galli, S.J., Nakae, S. \& Tsai, M. Mast cells in the development of adaptive immune responses. Nature immunology 6, 135-142 (2005).

152. Wang, H.W., Tedla, N., Lloyd, A.R., Wakefield, D. \& Wang, H.W., Tedla, N., Lloyd, A.R., Wakefield, D. \& lymph nodes during induction of an immune response in mice. The Journal of clinical investigation 102, 1617 1626 (1998).

153. McLachlan, J.B., et al. Mast cell-derived tumor necrosis factor induces hypertrophy of draining lymph nodes during infection. Nature immunology 4, 1199-1205 (2003).
154. Suto, H., et al. Mast cell-associated TNF promotes dendritic cell migration. J Immunol 176, 4102-4112 (2006)

155. Jawdat, D.M., Rowden, G. \& Marshall, J.S. Mast cells have a pivotal role in TNF-independent lymph node hypertrophy and the mobilization of Langerhans cells in response to bacterial peptidoglycan. J Immunol 177 1755-1762 (2006)

156. Jawdat, D.M., Albert, E.J., Rowden, G., Haidl, I.D. \& Marshall, J.S. IgE-mediated mast cell activation induces Langerhans cell migration in vivo. $J$ Immunol 173, 5275-5282 (2004)

157. McLachlan, J.B., et al. Mast cell activators: a new class of highly effective vaccine adjuvants. Nature medicine 14, 536-541 (2008).

158. Pulendran, B. \& Ono, S.J. A shot in the arm for mast cells. Nature medicine 14, 489-490 (2008).

159. Heib, V., Becker, M., Taube, C. \& Stassen, M Advances in the understanding of mast cell function. British journal of haematology 142, 683-694 (2008).

160. Brown, J.M., Wilson, T.M. \& Metcalfe, D.D. The mast cell and allergic diseases: role in pathogenesis and implications for therapy. Clinical and experimental allergy : journal of the British Society for Allergy and Clinical Immunology 38, 4-18 (2008).

161. Roda, G., et al. Intestinal epithelial cells in inflammatory bowel diseases. World $J$ Gastroenterol 16, 4264-4271.

162. Nejdfors, P., et al. Increased colonic permeability in patients with ulcerative colitis: an in vitro study Scandinavian journal of gastroenterology $33,749-753$ (1998)

163. Keita, A.V., et al. Increased uptake of non-pathogenic E. coli via the follicle-associated epithelium in longstanding ileal Crohn's disease. The Journal of pathology 215, 135-144 (2008).

164. Molodecky, N.A. \& Kaplan, G.G. Environmental risk factors for inflammatory bowel disease. Gastroenterology \& hepatology 6, 339-346.

165. Bamias, G., Nyce, M.R., De La Rue, S.A. \& Cominelli, $F$. New concepts in the pathophysiology of inflammatory bowel disease. Annals of internal medicine 143, 895-904 (2005).

166. Sasaki, Y., Tanaka, M. \& Kudo, H. Differentiation between ulcerative colitis and Crohn's disease by a quantitative immunohistochemical evaluation of $T$ lymphocytes, neutrophils, histiocytes and mast cells. Pathology international 52, 277-285 (2002).

167. De Winter, B.Y., van den Wijngaard, R.M. \& de Jonge, W.J. Intestinal mast cells in gut inflammation and motility disturbances. Biochimica et biophysica acta 1822, 66-73 (2012).

168. Marshall, J.K. \& Irvine, E.J. Ketotifen treatment of active colitis in patients with 5-aminosalicylate intolerance. Canadian journal of gastroenterology Journal canadien de gastroenterologie 12, 273-275 (1998).

169. Jones, N.L., Roifman, C.M., Griffiths, A.M. \& Sherman, $P$. Ketotifen therapy for acute ulcerative colitis in children: a pilot study. Digestive diseases and sciences 43, 609-615 (1998)

170. Tremaine, W.J., et al. Treatment of mildly to moderately active ulcerative colitis with a tryptase inhibitor (APC 2059): an open-label pilot study. Alimentary pharmacology \& therapeutics 16, 407-413 (2002).

171. Santos, J., Guilarte, M., Alonso, C. \& Malagelada, J.R. Pathogenesis of irritable bowel syndrome: the mast cell connection. Scandinavian journal of gastroenterology 40, 129-140 (2005).

172. Barbara, G., et al. Activated mast cells in proximity to colonic nerves correlate with abdominal pain in irritable bowel syndrome. Gastroenterology 126, 693-702 (2004).

173. Barbara, G., et al. New pathophysiological mechanisms in irritable bowel syndrome. Alimentary pharmacology \& therapeutics 20 Suppl 2, 1-9 (2004).

174. Morcos, A., Dinan, T. \& Quigley, E.M. Irritable bowe syndrome: role of food in pathogenesis and management. Journal of digestive diseases 10, 237246 (2009).

175. Mayer, E.A. \& Tillisch, K. The brain-gut axis in abdominal pain syndromes. Annual review of medicine 62, 381-396 (2011). 
176. Guilarte, M., et al. Diarrhoea-predominant IBS patients show mast cell activation and hyperplasia in the jejunum. Gut 56, 203-209 (2007).

177. Lee, H., et al. Mucosal mast cell count is associated with intestinal permeability in patients with diarrhea predominant irritable bowel syndrome. Journal of neurogastroenterology and motility 19, 244-250 (2013).

178. Martinez, C., et al. The jejunum of diarrheapredominant irritable bowel syndrome shows molecular alterations in the tight junction signaling pathway that are associated with mucosal pathobiology and clinical manifestations. The American journal of gastroenterology 107, 736-746 (2012)

179. Klooker, T.K., et al. The mast cell stabiliser ketotifen decreases visceral hypersensitivity and improves intestinal symptoms in patients with irritable bowel syndrome. Gut 59, 1213-1221 (2010).

180. Chrousos, G.P. The hypothalamic-pituitary-adrenal axis and immune-mediated inflammation. The New England journal of medicine 332, 1351-1362 (1995).

181. Wallon, C., et al. Eosinophils express muscarinic receptors and corticotropin-releasing factor to disrup the mucosal barrier in ulcerative colitis. Gastroenterology 140, 1597-1607 (2011).

182. Theoharides, T.C. \& Cochrane, D.E. Critical role of mast cells in inflammatory diseases and the effect of acute stress. Journal of neuroimmunology 146, 1-12 (2004).

183. Zareie, M., et al. Probiotics prevent bacterial translocation and improve intestinal barrier function in rats following chronic psychological stress. Gut $\mathbf{5 5}$ 1553-1560 (2006).

184. Gareau, M.G., Jury, J., MacQueen, G., Sherman, P.M. \& Perdue, M.H. Probiotic treatment of rat pups normalises corticosterone release and ameliorates colonic dysfunction induced by maternal separation. Gut 56, 1522-1528 (2007).

185. Eutamene, H., et al. Synergy between Lactobacillus paracasei and its bacterial products to counteract stress-induced gut permeability and sensitivity increase in rats. The Journal of nutrition 137, 1901-1907 (2007).

186. Gionchetti, P., Rizzello, F., Venturi, A. \& Campieri, M. Probiotics in infective diarrhoea and inflammatory bowel diseases. Journal of gastroenterology and hepatology 15, 489-493 (2000)

187. Kruis, $W$, et al. Maintaining remission of ulcerative colitis with the probiotic Escherichia coli Nissle 1917 is colitis with the probiotic Escherichia coli Nissle 1917 is
as effective as with standard mesalazine. Gut $\mathbf{5 3}$ 1617-1623 (2004).

188. Bibiloni, $R$, et al VSL\#3 probiotic-mixture induces remission in patients with active ulcerative colitis. The American journal of gastroenterology 100, 1539-1546 (2005).

189. Mayer, E.A., Naliboff, B.D., Chang, L. \& Coutinho, S.V. V. Stress and irritable bowel syndrome. American journal of physiology 280, G519-524 (2001)

190. Gwee, K.A., et al. Psychometric scores and persistence of irritable bowel after infectious diarrhoea. Lancet 347, 150-153 (1996).

191. McClave, S.A., Heyland, D.K. \& Wischmeyer, P.E. Comment on: probiotic prophylaxis in predicted severe acute pancreatitis: a randomized, double-blind, placebo-controlled trial. Jpen 33, 444-446 (2009).

192. Kelly, D., et al. Commensal anaerobic gut bacteria attenuate inflammation by regulating nuclearcytoplasmic shuttling of PPAR-gamma and RelA Nature immunology 5, 104-112 (2004).

193. Yamazaki, K., et al. Synergistic effects of RXR alpha and PPAR gamma ligands to inhibit growth in human colon cancer cells--phosphorylated RXR alpha is a critical target for colon cancer management. Gut $\mathbf{5 6}$ 1557-1563 (2007)

194. Linard, C., Gremy, O. \& Benderitter, M. Reduction of peroxisome proliferation-activated receptor gamma expression by gamma-irradiation as a mechanism contributing to inflammatory response in rat colon: modulation by the 5 -aminosalicylic acid agonist. The Journal of pharmacology and experimental therapeutics 324, 911-920 (2008).

195. Dubuquoy, L., et al. Impaired expression of peroxisome proliferator-activated receptor gamma in ulcerative colitis. Gastroenterology 124, 1265-1276 (2003).

196. Nencioni, A., et al. Dendritic cell immunogenicity is regulated by peroxisome proliferator-activated recepto gamma. J Immunol 169, 1228-1235 (2002).
197. Su, C.G., et al. A novel therapy for colitis utilizing PPAR-gamma ligands to inhibit the epithelial inflammatory response. The Journal of clinical investigation 104, 383-389 (1999).

198. Desreumaux, P., et al. Attenuation of colon inflammation through activators of the retinoid $X$ receptor (RXR)/peroxisome proliferator-activated receptor gamma (PPARgamma) heterodimer. A basis for new therapeutic strategies. The Journal of experimental medicine 193, 827-838 (2001).

199. Ewaschuk, J., et al. Probiotic bacteria prevent hepatic damage and maintain colonic barrier function in mouse model of sepsis. Hepatology 46, 841-850 (2007).

200. Ponferrada, A., et al. The role of PPARgamma on restoration of colonic homeostasis after experimental stress-induced inflammation and dysfunction. Gastroenterology 132, 1791-1803 (2007).

$201 . \quad$ Madsen, $\mathrm{K}$, et al. Probiotic bacteria enhance murine and human intestinal epithelial barrier function. Gastroenterology 121, 580-591 (2001).

202. Jijon, H., et al. DNA from probiotic bacteria modulates murine and human epithelial and immune function. Gastroenterology 126, 1358-1373 (2004).

203. Amidon, G.L., Lennernas, H., Shah, V.P. \& Crison, J.R A theoretical basis for a biopharmaceutic drug classification: the correlation of in vitro drug product dissolution and in vivo bioavailability. Pharmaceutical research 12, 413-420 (1995).

204. Hou, T., Wang, J., Zhang, W., Wang, W. \& Xu, X Recent advances in computational prediction of drug absorption and permeability in drug discovery. Current medicinal chemistry 13, 2653-2667 (2006).

$205 . \quad$ Moss, D.M., Siccardi, M., Back, D.J. \& Owen, A Predicting intestinal absorption of raltegravir using a population-based ADME simulation. The Journal of antimicrobial chemotherapy 68, 1627-1634 (2013).

206. Antunes, F., Andrade, F., Ferreira, D., Nielsen, H.M. \& Sarmento, B. Models to predict intestinal absorption of therapeutic peptides and proteins. Current drug metabolism 14, 4-20 (2013).

207. Polli, J.E. In vitro studies are sometimes better than conventional human pharmacokinetic in vivo studies in assessing bioequivalence of immediate-release solid oral dosage forms. The AAPS journal 10, 289-299 (2008).

$208 . \quad$ Lesuffleur, T., Barbat, A., Dussaulx, E. \& Zweibaum, A. Growth adaptation to methotrexate of HT-29 human colon carcinoma cells is associated with their ability to differentiate into columnar absorptive and mucussecreting cells. Cancer research 50, 6334-6343 (1990).

209. Walter, E., Janich, S., Roessler, B.J., Hilfinger, J.M. \& Amidon, G.L. HT29-MTX/Caco-2 cocultures as an in vitro model for the intestinal epithelium: in vitro-in vivo correlation with permeability data from rats and humans. Journal of pharmaceutical sciences 85,1070 1076 (1996)

210. Antunes, F., Andrade, F., Araujo, F., Ferreira, D. \& Sarmento, B. Establishment of a triple co-culture in vitro cell models to study intestinal absorption of peptide drugs. European journal of pharmaceutics and biopharmaceutics : official journal of Arbeitsgemeinschaft fur Pharmazeutische Verfahrenstechnik e.V 83, 427-435 (2013).

211. Bjarnason, I., MacPherson, A. \& Hollander, D Intestinal permeability: an overview. Gastroenterology 108, 1566-1581 (1995)

212. Chiou, W.L. \& Buehler, P.W. Comparison of ora absorption and bioavailablity of drugs between monkey and human. Pharmaceutical research 19, 868-874 (2002).

213. Sunesen, V.H., Pedersen, B.L., Kristensen, H.G. \& Mullertz, A. In vivo in vitro correlations for a poorly soluble drug, danazol, using the flow-through dissolution method with biorelevant dissolution media. European journal of pharmaceutical sciences : official journal of the European Federation for Pharmaceutical Sciences 24, 305-313 (2005).

214. Nejdfors, P., Ekelund, M., Jeppsson, B. \& Westrom B.R. Mucosal in vitro permeability in the intestinal tract of the pig, the rat, and man: species- and regionrelated differences. Scandinavian journal of gastroenterology 35, 501-507 (2000).

215. Keita, A.V., et al. Increased uptake of non-pathogenic E. coli via the follicle-associated epithelium in 

function. Am.J.Physiol Gastrointest.Liver Physiol 280 G7-G13 (2001).

218. Soderholm J.D et al. Chronic stress induces mast cell-dependent bacterial adherence and initiates mucosal inflammation in rat intestine. Gastroenterology 123, 1099-1108 (2002)

219. Vollmayr, B., Mahlstedt, M.M. \& Henn, F.A Neurogenesis and depression: what animal models tell us about the link. European archives of psychiatry and clinical neuroscience 257, 300-303 (2007).

$220 . \quad B a r o n e, F . C$. et al. Cold-restraint stress increases rat fecal pellet output and colonic transit. The American journal of physiology 258, G329-337 (1990)

221. Melgar, S., et al. Validation of murine dextran sulfate sodium-induced colitis using four therapeutic agents for human inflammatory bowel disease. International immunopharmacology 8, 836-844 (2008).

222. Sambuy, Y., et al. The Caco-2 cell line as a model of the intestinal barrier: influence of cell and culturerelated factors on Caco-2 cell functional characteristics. Cell biology and toxicology 21, 1-26 (2005).

223. E, G. Particle transytosis across the human intestina

epithelium [Dissertation].Pharmacy, Uppsala University, Sweden. Dissertation (2005)

(a., Mandel, K.G., Tisdale, L.D. \& Masui, H. A human colonic tumor cell line that maintains vectorial electrolyte transport. The American journal of physiology 246, G204-208 (1984).

225. Eccleston, E., Leonard, B.J., Lowe, J.S. \& Welford, H.J. Basophilic leukaemia in the albino rat and a demonstration of the basopoietin. Nature: New biology 244, 73-76 (1973)

226. Rashid, A., et al. Review: Diagnostic and therapeutic applications of rat basophilic leukemia cells. Molecular immunology 52, 224-228 (2012).

227. Pulvertaft, J.V. Cytology of Burkitt's Tumour (African Lymphoma). Lancet 1, 238-240 (1964).

228. Epstein, M.A. \& Barr, Y.M. Characteristics and Mode of Growth of Tissue Culture Strain (Eb1) of Human Lymphoblasts from Burkitt's Lymphoma. Journal of the National Cancer Institute 34, 231-240 (1965)

229. Duncan, S.H., Hold, G.L., Harmsen, H.J., Stewart, C.S. \& Flint, H.J. Growth requirements and fermentation products of Fusobacterium prausnitzii, and a proposa to reclassify it as Faecalibacterium prausnitzii gen. nov., comb. nov. International journal of systematic and evolutionary microbiology 52, 2141-2146 (2002).

230. Miquel, S., et al. Faecalibacterium prausnitzii and human intestinal health. Current opinion in human intestinal health.
microbiology 16, 255-261 (2013).

231. Hold, G.L., Schwiertz, A., Aminov, R.I., Blaut, M. \& Flint, H.J. Oligonucleotide probes that detect quantitatively significant groups of butyrate-producing bacteria in human feces. Applied and environmental microbiology 69, 4320-4324 (2003)

232. Flint, H.J., Scott, K.P., Duncan, S.H., Louis, P. \& Forano, E. Microbial degradation of complex carbohydrates in the gut. Gut microbes 3, 289-306 (2012).

233. Duncan, S.H., Louis, P. \& Flint, H.J. Lactate-utilizing bacteria, isolated from human feces, that produce butyrate as a major fermentation product. Applied and environmental microbiology 70, 5810-5817 (2004).

234. Macfarlane, G.T. \& Macfarlane, S. Fermentation in the human large intestine: its physiologic consequences and the potential contribution of prebiotics. Journal of clinical gastroenterology 45 Suppl, S120-127 (2011).

235. Sokol, H., et al. Faecalibacterium prausnitzii is an antiinflammatory commensal bacterium identified by gut microbiota analysis of Crohn disease patients. Proceedings of the National Academy of Sciences of the United States of America 105, 16731-16736 (2008).

236. Ussing, H.H. \& Zerahn, K. Active transport of sodium as the source of electric current in the short-circuited isolated frog skin. Acta physiologica Scandinavica 23, 110-127 (1951).

237. Grass, G.M. \& Sweetana, S.A. In vitro measurement of gastrointestinal tissue permeability using a new

diffusion cell. Pharmaceutical research 5, 372-376 (1988).

238. Karlsson, J. Drug absorption in cell culture models of the intestinal epithelium [Dissertation] Pharmaceuticals, Uppsala University, Sweden. (1995).

239. Kerneis, S Bogdanova A Kraehenbuhl, J.P. \& Pringault, E. Conversion by Peyer's patch lymphocytes of human enterocytes into $M$ cells that transport bacteria. Science 277, 949-952 (1997).

240. Gullberg, E., et al. Expression of specific markers and particle transport in a new human intestinal M-cell model. Biochemical and biophysical research communications 279, 808-813 (2000).

241. Keita, A.V., et al. Characterization of antigen and bacterial transport in the follicle-associated epithelium of human ileum. Laboratory investigation; a journal of technical methods and pathology 86, 504-516 (2006).

242. Roberts, C.L., et al. Translocation of Crohn's disease Escherichia coli across M-cells: contrasting effects of soluble plant fibres and emulsifiers. Gut 59, 1331-1339 (2010)

243. Soderholm, J.D., et al. Integrity and metabolism of human ileal mucosa in vitro in the Ussing chamber. Acta physiologica Scandinavica 162, 47-56 (1998).

244. Wallon, C., Braaf, Y., Wolving, M., Olaison, G. \& Soderholm, J.D. Endoscopic biopsies in Ussing chambers evaluated for studies of macromolecular permeability in the human colon. Scandinavian journal of gastroenterology 40, 586-595 (2005)

245. Amasheh, M., et al. Regulation of mucosal structure and barrier function in rat colon exposed to tumor necrosis factor alpha and interferon gamma in vitro: a novel model for studying the pathomechanisms of inflammatory bowel disease cytokines. Scandinavian journal of gastroenterology 44, 1226-1235 (2009).

246. Bjorkman, E., Casselbrant, A., Lundberg, S. \& Fandriks, L. In vitro assessment of epithelial electrical resistance in human esophageal and jejunal mucosae and in Caco-2 cell layers. Scandinavian journal of gastroenterology 47, 1321-1333 (2012)

247. Passante, E., Ehrhardt, C., Sheridan, H. \& Frankish, N. Toll-like receptors and RBL-2H3 mast cells. Inflammation research : official journal of the European Histamine Research Society ... [et al.] 58 Suppl 1, 11 12 (2009)

248. Lutgendorff, F., Akkermans, L.M. \& Soderholm, J.D. The role of microbiota and probiotics in stress-induced gastro-intestinal damage. Current molecular medicine 8, 282-298 (2008)

249. Wilhelmsen, The role of psychosocial factors in gastrointestinal disorders. Gut 47 Suppl 4, iv73-75; discussion iv76 (2000).

250. Levenstein, S., et al. Stress and exacerbation in ulcerative colitis: a prospective study of patients enrolled in remission. The American journal of gastroenterology 95, 1213-1220 (2000).

251. Larauche, M., Kiank, C. \& Tache, Y. Corticotropin releasing factor signaling in colon and ileum: regulation by stress and pathophysiological implications. Journal of physiology and pharmacology : an official journal of the Polish Physiological Society 60 Suppl 7, 33-46 (2009).

252. Neunlist, $M$., et al. Human ENS regulates the intestina epithelial barrier permeability and a tight junctionassociated protein ZO-1 via VIPergic pathways. Am.J Physiol Gastrointest.Liver Physiol. 285, G1028-G1036 (2003).

253. Abad, C., et al. Therapeutic effects of vasoactive intestinal peptide in the trinitrobenzene sulfonic acid mice model of Crohn's disease. Gastroenterology. 124 961-971 (2003).

254. Delgado, M. \& Ganea, D Inhibition of endotoxininduced macrophage chemokine production by VIP and PACAP in vitro and in vivo. Arch.Physiol Biochem. 109, 377-382 (2001).

255. Zhongkai, L., Jianxin, Y. \& Weichang, C. Vasoactive intestinal peptide promotes gut barrier function against severe acute pancreatitis. Molecular biology reports 39 , 3557-3563 (2012).

256. Moriez, R., et al. Neuroplasticity and neuroprotection in enteric neurons: role of epithelial cells. Biochem.Biophys.Res.Commun. 382, 577-582 (2009).

257. Bakker, R., Dekker, K., De Jonge, H.R. \& Groot, J.A VIP, serotonin, and epinephrine modulate the ion selectivity of tight junctions of goldfish intestine. Am.J.Physiol. 264, R362-R368 (1993). 
258. Delgado, M. VIP: a very important peptide in T helper differentiation. Trends Immunol 24, 221-224 (2003).

259. Yadav, M., Rosenbaum, J. \& Goetzl, E.J. Cutting edge: vasoactive intestinal peptide (VIP) induces differentiation of Th17 cells with a distinctive cytokine profile. J Immunol 180, 2772-2776 (2008).

260. Delgado, M. \& Ganea, D. Vasoactive intestinal peptide inhibits IL-8 production in human monocytes. Biochemical and biophysical research communications 301, 825-832 (2003).

261. Vodenicharov, A., Leiser, R., Gulubova, M. \& Vlaykova, T. Morphological and immunocytochemical investigations on mast cells in porcine ureter Anat.Histol.Embryol. 34, 343-349 (2005).

262. Groneberg, D.A., et al. Down-regulation of vasoactive intestinal polypeptide receptor expression in atopic dermatitis. J Allergy Clin.Immunol. 111, 1099-1105 (2003)

263. Lowman, M.A., Benyon, R.C. \& Church, M.K. Characterization of neuropeptide-induced histamine release from human dispersed skin mast cells. British journal of pharmacology 95, 121-130 (1988)

264. Keita, A.V. Soderholm, J.D. \& Ericson, A.C. Stressinduced barrier disruption of rat follicle-associated epithelium involves corticotropin-releasing hormone, acetylcholine, substance $\mathrm{P}$, and mast cells. Neurogastroenterology and motility : the official journal of the European Gastrointestinal Motility Society 22 770-778, e221-772 (2010).

265. Fujimoto, T., et al. Decreased abundance of Faecalibacterium prausnitzii in the gut microbiota of Crohn's disease. Journal of gastroenterology and hepatology (2012).

266. Willing, B.P., et al. A pyrosequencing study in twins shows that gastrointestinal microbial profiles vary with inflammatory bowel disease phenotypes. Gastroenterology 139, 1844-1854 e1841 (2010).

267. Seksik, P., et al. Alterations of the dominant faecal bacterial groups in patients with Crohn's disease of the colon. Gut 52, 237-242 (2003).

268. Pineiro, M. \& Stanton, C. Probiotic bacteria: legislative framework-- requirements to evidence basis. The Journal of nutrition 137, 850S-853S (2007).

269. Garcia-Lafuente, A., Antolin, M., Guarner, F., Crespo, E. \& Malagelada, J.R. Modulation of colonic barrie function by the composition of the commensal flora in the rat. Gut 48, 503-507 (2001).

270. Gionchetti, P., Lammers, K.M., Rizzello, F. \& Campieri, M. VSL\#3: an analysis of basic and clinical contributions in probiotic therapeutics. Gastroenterology clinics of North America 34, 499-513, ix-x (2005).
271. Magerl, M., et al. Non-pathogenic commensal Escherichia coli bacteria can inhibit degranulation of mast cells. Experimental dermatology 17, 427-435 (2008)

272. Persborn, M., et al. The effects of probiotics on barrie function and mucosal pouch microbiota during maintenance treatment for severe pouchitis in patients with ulcerative colitis. Alimentary pharmacology \& therapeutics 38, 772-783 (2013).

273. Besselink, M.G. et al. [Probiotic prophylaxis in patients with predicted severe acute pancreatitis: a randomised double-blind, placebo-controlled trial]. Nederlands tijdschrift voor geneeskunde 152, 685-696 (2008).

274. Bissonnette, E.Y., Chin, B. \& Befus, A.D. Interferon differentially regulate histamine and TNF-alpha in rat intestinal mucosal mast cells. Immunology 86, 12-17 (1995).

275. Leal-Berumen, I., O'Byrne, P., Gupta, A., Richards, C.D. \& Marshall, J.S. Prostanoid enhancement of interleukin- 6 production by rat peritoneal mast cells. $J$ Immunol 154, 4759-4767 (1995).

276. Marshall, J.S., Leal-Berumen, I., Nielsen, L., Glibetic, M. \& Jordana, M. Interleukin (IL)-10 inhibits long-term IL-6 production but not preformed mediator release from rat peritoneal mast cells. The Journal of clinical investigation 97, 1122-1128 (1996).

277. Lewis, R.A., et al. Prostaglandin D2 generation after activation of rat and human mast cells with anti-lgE. $J$ Immunol 129, 1627-1631 (1982).

278. Kliewer, S.A., Xu, H.E., Lambert, M.H. \& Willson, T.M. Peroxisome proliferator-activated receptors: from genes to physiology. Recent progress in hormone research 56, 239-263 (2001).

279. Ricote, M., Li, A.C., Willson, T.M., Kelly, C.J. \& Glass C.K. The peroxisome proliferator-activated receptorgamma is a negative regulator of macrophage activation. Nature 391, 79-82 (1998).

280. Ewaschuk, J.B., Walker, J.W., Diaz, H. \& Madsen, K.L. Bioproduction of conjugated linoleic acid by probiotic bacteria occurs in vitro and in vivo in mice. The Journal of nutrition 136, 1483-1487 (2006).

281. Clark R. The role of PPARs in inflammation and immunity. Journal of leukocyte biology $71,388-400$ (2002)

282. Petrof, E.O., et al. Probiotics inhibit nuclear factorkappaB and induce heat shock proteins in colonic epithelial cells through proteasome inhibition. Gastroenterology 127, 1474-1487 (2004). 